Guilherme Cardinali Barreiro

\title{
Estudo da anatomia dos retalhos pediculados da artéria torácica interna e sua aplicabilidade na reconstrução de cabeça e pescoço.
}

Tese apresentada à Faculdade de Medicina da Universidade de São Paulo para obtenção do título de Doutor em Ciências

Programa de Clínica Cirúrgica Orientador: Prof. Dr. Marcus Castro Ferreira

São Paulo 2014 
Dados Internacionais de Catalogação na Publicação (CIP)

Preparada pela Biblioteca da

Faculdade de Medicina da Universidade de São Paulo

Creprodução autorizada pelo autor

Barreiro, Guilherme Cardinali

Estudo da anatomia dos retalhos pediculados da artéria torácica interna e sua aplicabilidade na reconstrução de cabeça e pescoço / Guilherme Cardinali Barreiro. -- São Paulo, 2014.

Tese(doutorado)--Faculdade de Medicina da Universidade de São Paulo.

Programa de Clínica Cirúrgica.

Orientador: Marcus Castro Ferreira.

Descritores: 1.Retalhos cirúrgicos 2.Procedimentos cirúrgicos reconstrutivos 3.Dissecação 4. Artéria torácica interna 5. Costelas 6.Cabeça 7.Pescoço 8.Mandíbula 9.Retalho perfurante 10.Retalho miocutâneo 11.Reto do abdome

USP/FM/DBD-449/14 
Aos meus amados pais Carlos e Fátima e amada companheira Rachel. 
Agradecimentos 
A execução desta tese só foi possível graças à colaboração de diversas pessoas, a quem devo minha profunda gratidão, em especial:

Ao meus pais Carlos José e Maria de Fátima, pelo carinho e orientação durante toda minha vida.

Ao meu irmão Felipe pelos conselhos, amizade e companheirismo.

À Dra. Rachel Rossine Baptista, pelo companheirismo, amor, dedicação e colaboração em todas as etapas do trabalho e da minha vida.

Ao Prof. Dr. Marcus Castro Ferreira, Professor Titular da Disciplina de Cirurgia Plástica da Faculdade de Medicina da Universidade de São Paulo, meu orientador, pelo apoio e orientação.

Ao Dr. Paulo Tuma Jr pela tutoração e dedicação na minha formação pessoal, espiritual e profissional.

Ao Dr. Eduardo Arruda pelo incentivo, amizade e companheirismo na vida pessoal e profissional.

Aos Dr. Fabio Busnardo e Dr. Eduardo Montag pelos ensinamentos e condução na idealização do projeto.

Ao Dr. Fabio Gaiotto pela orientação e participação no campo da cirurgia torácica.

Aos Drs Allysson Doi e Hélio Alves pelo companheirismo e amizade no campo da cirurgia reconstrução de cabeça e pescoço. 
Aos Dr. Júlio Morais, Prof. Dr. José Carlos Faria e Dr. Luiz Carlos Ishida, grandes mentores no campo da cirurgia reconstrutiva.

Aos Prof. Dr. Henri Friedhofer, Prof. Dr. Rolf Gemperli, Dr. Miguel Modolin, Prof. Dr. Nivaldo Alonso, Prof. Dr. Dov Goldenberg pelos valiosos ensinamentos e cuidados dispensados na minha formação como cirurgião plástico.

Aos Dr Kiril Endo Kasai e Dr. Daniel Marchi dos Anjos pela colaboração permanente na minha vida científica e pessoal.

Aos Drs. Ricardo Custódio, Dr Thiago Mendaçolli, Dr Fernando Tovo, Dr. João Bragnanollo, e Dr. Alex Fioravanti pela participação nas dissecações no serviço de verificação de óbitos.

Aos residentes de cirurgia plástica do HC FMUSP pelo auxílio nas cirurgias, documentação e cuidado dos pacientes operados.

À Sra. Julia Fukushima pela análise e revisão estatística dos dados apresentados nesta tese.

À Sra. Eliane Gazzetto pela condução nas etapas burocráticas da pós graduação. 
"A tarefa não é tanto ver aquilo que ninguém viu, mas pensar o que ninguém ainda pensou sobre aquilo que todo mundo vê."

Arthur Schopenhauer 
Esta tese está de acordo com as seguintes normas, em vigor no momento desta publicação:

Referências: adaptado de International Commitee of Medical Journals Editors (Vancouver).

Universidade de São Paulo. Faculdade de Medicina. Serviço de Biblioteca e Documentação. Guia de apresentação de dissertações teses e monografias. Elaborado por Annelise Carneiro da Cunha, Maria Julia de A. L. Freddi, Maria F. Crestana, Marinalva de Souza Aragão, Suely de Campos Cardoso, Valéria Vilhena. 3ª̣ ed. São Paulo: Serviço de Biblioteca e Documentação; 2011.

Abreviaturas dos títulos dos periódicos de acordo com List of Journals Indexed in the Index Medicus. 
Sumário 


\section{Sumário}

Lista de abreviaturas e siglas.......................................................................... xi

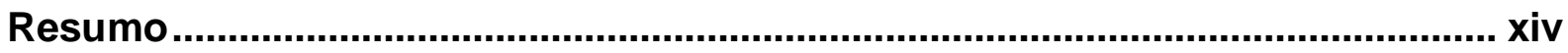

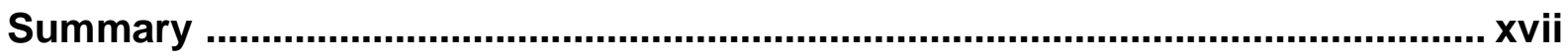

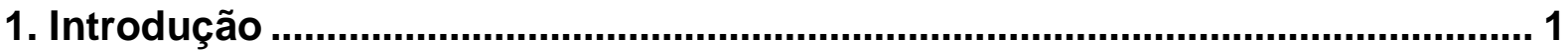

1.1. Epidemiologia da Reconstrução em Cabeça e Pescoço ................................. 2

1.2. Alternativas em Situações com Ausência de Vasos Receptores Cervicais ...... 3

1.3. Anatomia da Artéria Torácica Interna, suas ramificações e perfurantes ......... 4

1.4. Aplicabilidade dos Retalhos Pediculados na Artéria Torácica Interna em

Reconstruções de Cabeça e Pescoço ............................................................... 6

1.5. Correlação Anátomo-Clínica no Uso dos Retalhos Pediculados na Artéria

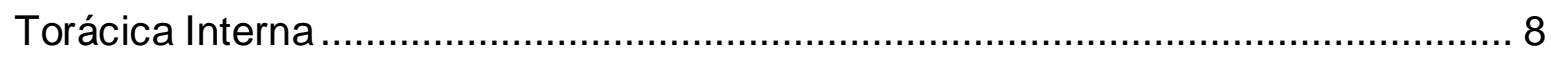

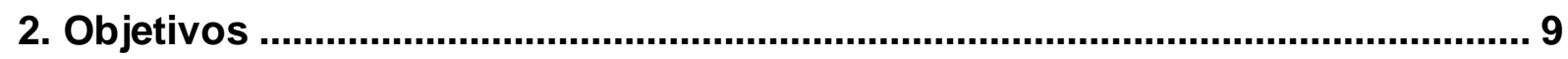

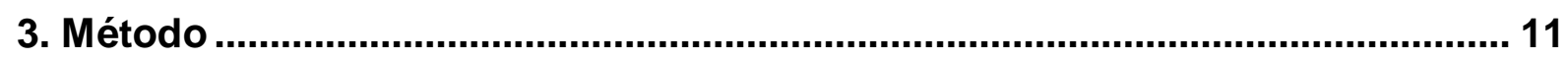

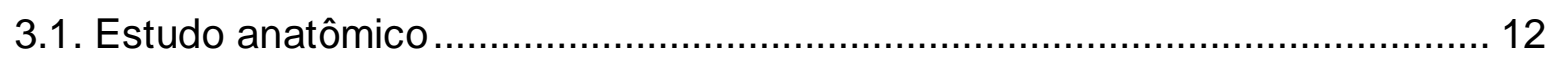

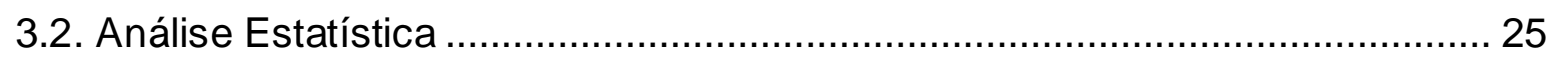

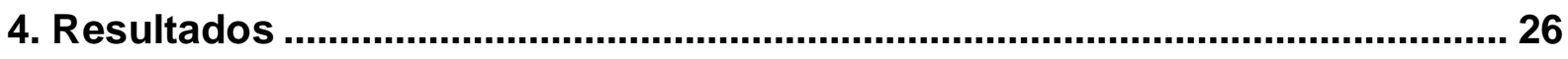

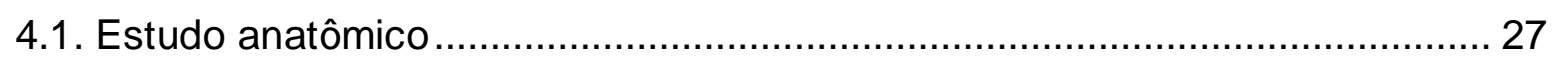

4.1.1. Vasos epigástricos superiores superficiais (SSEA) ............................. 27

4.1.2. Retalho osteomiocutâneo baseado nos vasos torácicos internos............ 34

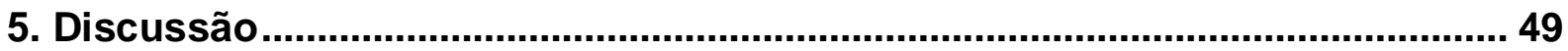

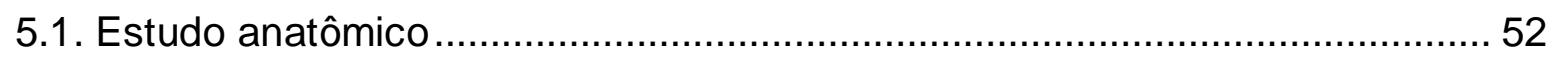

5.1.1. Vasos epigástricos superiores superficiais (SSEA) .............................. 52

5.1.2. Retalho osteomiocutâneo baseado nos vasos torácicos internos............ 53

5.2. Aplicabilidade Clínica ......................................................................... 58

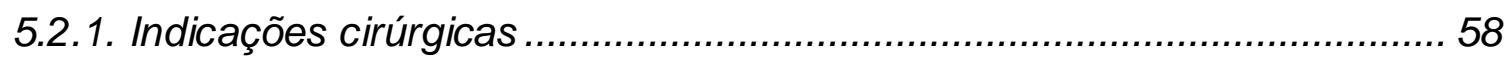




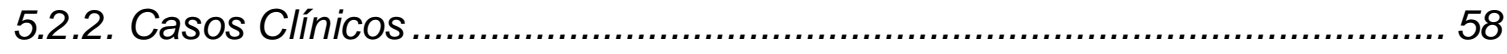

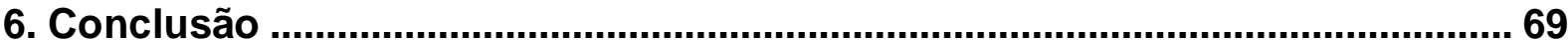

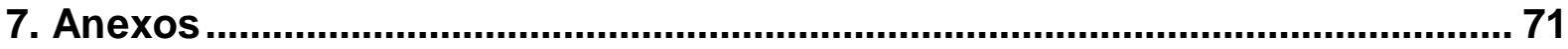

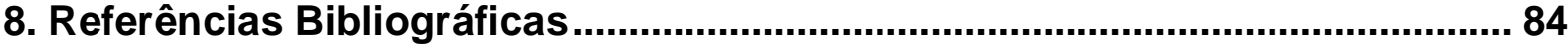


Lista de abreviaturas e siglas 


\section{Lista de abreviaturas e Siglas}

IMAP: vasos perfurantes da artéria torácica interna (internal mammary artery perforator)

HCFMUSP: Hospital das Clínicas da Faculdade de Medicina da Universidade de São Paulo

EIC: espaço intercostal

DSEA: artéria epigástrica superior profunda (deep superior epigastric artery)

DIEA: artéria epigástrica inferior profunda (deep inferior epigastric artery)

SSEA: artéria epigástrica superior superficial (superficial superior epigastric artery)

SVOC-USP: serviço de verificação de óbitos da capital - Universidade de São Paulo

®): marca registrada

Fig.: figura

dp: desvio-padrão

M: média

p: nível descritivo

r: razão

m: metros

cm: centímetros

mm: milímetros

Kg: quilogramas

n: número

CEC: carcinoma espinocelular

PGM: cirurgia de pelveglossomandibulectomia

ECRM: linfadenectomia cervical com esvaziamento cervical radical modificado

SOH: linfadenectomia cervical com esvaziamento cervical supra-homohióideo

E: esquerda

D: direita

Neurop.: neuropraxia

QTX: quimioterapia

$\mathrm{RTX}$ : radioterapia 
VRAM: retalho miocutâneo de músculo reto abdominal com ilha de pele transversal ALT: retalho fasciocutâneo anterolateral da coxa 
Resumo 
Barreiro GC. Estudo da anatomia dos retalhos pediculados da artéria torácica interna e sua aplicabilidade na reconstrução de cabeça e pescoço [Tese]. São Paulo: Faculdade de Medicina, Universidade de São Paulo; 2014.

INTRODUÇÃO: As reconstruções com tecidos combinados e bem vascularizados permitem a melhor reabilitação para defeitos extensos em cabeça e pescoço. $O$ padrão-ouro tem sido as transferências microcirúrgicas de tecidos. Porém, há pacientes em que não há vasos receptores cervicais adequados para os transplantes de tecidos livres devido à múltiplas recidivas, ressecções e reconstruções; linfadenectomias cervicais; fístulas e infecções; e o tratamento com radioterapia. Com o aprimoramento do controle oncológico, pacientes nestas circunstâncias são cada vez mais frequentes e há poucas alternativas para reconstrução. OBJETIVO: Descrever a dissecação anatômica de um retalho osteomiocutâneo combinado, pediculado nos vasos torácicos internos, para reconstrução de defeitos complexos em cabeça e pescoço. MÉTODO: Retalhos osteomiocutâneos contendo $6^{\underline{a}}$ e $7^{\text {a }}$ costelas e músculo reto abdominal foram dissecados bilateralmente em 35 cadáveres, 26 do sexo masculino e 9 do sexo feminino. Estudou-se a vascularização cutânea do abdome superior pelas perfurantes da artéria epigástrica superior superficial (SSEA); e os padrões de vascularização do $6^{\circ}$ e $7^{\circ}$ arcos costais e músculo reto abdominal a partir dos vasos torácicos internos, musculofrênicos e intercostais. $O$ arco de rotação para segmento cefálico com ponto pivô na margem inferior da primeira costela foi avaliado. RESULTADOS: Foram dissecadas 114 perfurantes SSEA, 62 à direita e 52 à esquerda, com calibre arterial médio homogêneo de 0,68 $\mathrm{mm}$. A maior frequência de perfurantes encontradas foi no grupo de 0,5 a 1,0 mm, com 60 (52,7\%) ocorrências. Não houve diferença estatisticamente significativa para localização e calibre em relação ao lado. Também não houve correlação dos calibres com localização, idade, peso e altura dos cadáveres. Sessenta e dois retalhos osteomiocutâneos com pedículo nos vasos torácicos internos, $6^{\circ}$ e $7^{\circ}$ arcos costais e músculo reto abdominal foram divididos em 3 tipos de acordo com o padrão de vascularização do sexto arco costal. O tipo 1, em que a vascularização da sexta costela é pela artéria musculofrênica, foi o mais frequente, com 46 (74,2\%) ocorrências. Dez pedículos vasculares diferentes para os componentes do retalho foram individualizados e 
medidos bilateralmente. Apenas quatro foram significativamente maiores nos homens e, dois, maiores à direita. Os calibres de todos os pedículos arteriais foram homogêneos em relação ao sexo e ao lado. O comprimento do pedículo para o componente ósseo do retalho variou de 18,5 a 21,6 cm, alcançando mandíbula e maxila em todos as dissecações. Já o componente miocutâneo do reto abdominal atingiu occipício em todos os casos e levou os vasos epigástricos profundos inferiores para possível anastomose vascular. Cinco pacientes foram operados em 2 anos com adequada integração dos retalhos e recuperação do contorno e função mandibulares. CONCLUSÃO: Em todas as dissecações de cadáver as perfurantes SSEA estiveram presentes bilateralmente com calibre maior que $0,3 \mathrm{~mm}$; os retalhos osteomiocutâneos pediculados nos vasos torácicos internos foram constantes e alcançaram o segmento cefálico. Os pacientes operados recuperaram forma e função mandibulares. Este retalho pode ser uma alternativa para reconstruções secundárias em cabeça e pescoço.

Descritores: Retalhos cirúrgicos, procedimentos cirúrgicos reconstrutivos, dissecação, artéria torácica interna, costelas, cabeça, pescoço, mandíbula, retalho perfurante, retalho miocutâneo, reto do abdome. 
Summary 
Barreiro GC. The anatomy of the internal mammary artery pedicled flaps and their use in head and neck reconstructions [Thesis]. São Paulo: "Faculdade de Medicina, Universidade de São Paulo"; 2014.

INTRODUCTION: The use of combined well-vascularized flaps offers better results and rehabilitation for complex head and neck defects. Microsurgical reconstructions are the gold standard. However, there are patients with vessel-depleted necks from multiple recurrences and resections, failed reconstructions, neck dissections, infections, fistulas and radiotherapy, which impair adequate free tissue transfers. With better oncologic therapies, these patients have become more common and lack reconstructive options. OBJECT: To describe a combined ostemyocutaneous pedicled flap based on the internal mammary artery for complex head and neck reconstructions. METHOD: Osteomyocutaneous flaps with $6^{\text {th }}$ and $7^{\text {th }}$ ribs and the rectus abdominis muscle were dissected bilaterally on 35 cadavers, 26 male and 9 female. We studied the upper abdominal irrigation through isolation of the superficial superior epigastric artery perforators (SSEA) and the vascular pedicles to the $6^{\text {th }}$ and $7^{\text {th }}$ ribs, and the rectus abdominis muscle arising from the internal mammary, the musculophrenic and the intercostal arteries. The arc of rotation of the flap to the cephalic segment was tested with the pivot point on the lower margin of the first rib. RESULTS: We dissected 114 SSEA, 62 on the right side and 52 on the left. They had an homogeneous mean arterial diameter of $0,68 \mathrm{~mm}$. Sixty perforators $(52,7 \%)$ were on the group that ranged from 0,5 to $1,0 \mathrm{~mm}$. After statistical analysis, there were no differences in relation to the side as for location and caliber of the perforators. Neither there was any relation of the arterial calibers to the location, age, weight and height of the cadavers. Sixty-two internal mammary artery pedicled osteomyocutaneous flaps, that carried the $6^{\text {th }}$ and $7^{\text {th }}$ ribs and the rectus abdominis muscle, were divided in 3 types depending on the vascular pattern to the $6^{\text {th }}$ costal arch. Type 1 , where the pedicle to the $6^{\text {th }}$ rib branches from the musculophrenic artery, was the most frequent and dissected in 46 flaps (74,2\%). Ten different vascular pedicles to the components of the flap were isolated and measured bilaterally. Only four of them were significantly longer in males and, two, were longer on the right side. The arterial diameters were also homogeneous in relation to the side and sex. The pedicle length to the osseous component of the flap varied from 
18,5 to $21,6 \mathrm{~cm}$, which allowed to reach mandible and maxilla in all dissections. The myocutaneous component of the rectus abdominis muscle reached the occipitum in all cases and carried along the deep inferior epigastric vessels for vascular anastomosis if needed. Five patients were operated in 2 years with adequate flap integration and recovery of the mandible contour and function. CONCLUSION: In all cadaveric dissections SSEA perforators were bilaterally present with a caliber bigger than $0,3 \mathrm{~mm}$; internal mammary artery osteomyocutaneous pedicled flaps were constant and reached the cephalic segment. The operated patients recovered mandibular form and function. This flap can be an alternative for secondary head and neck reconstructions.

Descriptors: surgical flaps, reconstructive surgical procedure, dissection, mammary arteries, ribs, head, neck, mandible, perforator flap, myocutaneous flap, rectus abdominis. 
1. Introdução 


\section{Estudo da anatomia dos retalhos pediculados da artéria torácica interna e sua aplicabilidade na reconstrução de cabeça e pescoço.}

\subsection{Epidemiologia da Reconstrução em Cabeça e Pescoço}

A reconstrução de cabeça e pescoço é um ramo desafiador dentro da cirurgia plástica e seu desenvolvimento permite maiores ressecções oncológicas com melhor reabilitação. ${ }^{1}$ Nos últimos anos, apesar das campanhas governamentais de controle dos fatores de risco, como as medidas de restrição ao uso do tabaco, a incidência de ressecções em cabeça e pescoço tem aumentado. ${ }^{2}$ Corroboram para este crescimento o aumento da incidência de câncer nesta região, devido ao melhor acesso aos serviços de saúde e melhores técnicas diagnósticas; e à ampliação dos recursos cirúrgicos associados ao desenvolvimento dos tratamentos adjuvantes.

Desde 1973, com o primeiro relato de transferência microcirúrgica de um retalho por Daniel e Taylor, o uso de retalhos livres passou a ser amplamente empregado em reconstrução de cabeça e pescoço com a obtenção de bons resultados. $^{3-6}$ Esta técnica permite ao cirurgião escolher o retalho baseado na morbidade das áreas doadoras, na quantidade de tecido a ser utilizada, na composição dos tecidos do retalho e nas características de cada pedículo; sem depender da disponibilidade de retalhos locais, que possuem alcance e viabilidade limitados. ${ }^{1,7}$ Retalhos livres fornecem suprimento vascular robusto, permitindo melhor cobertura e contorno com o uso de osso vascularizado e outros tecidos combinados. $^{7}$

A disponibilidade de vasos receptores patentes nos arredores da área a ser reconstruída é fundamental para o sucesso da reconstrução microcirúrgica. Dissecações e linfadenectomias cervicais, associadas à radioterapia, comprometem a existência de vasos receptores para a transferência de retalhos livres. ${ }^{1,8,9} \mathrm{~A}$ melhora da sobrevida dos pacientes cursa com recidivas tumorais e novos tumores primários em outros sítios anatômicos. Muitos pacientes apresentam-se ao cirurgião reconstrutor já tendo sido submetidos a duas ou mais reconstruções com retalhos livres ou locorregionais. ${ }^{10-14}$ Eles podem ter fístulas salivares, sequelas de infecção, exposições ósseas e osteorradionecrose. ${ }^{11,15}$ Esta situação tornou-se mais comum 
no tratamento oncológico em cabeça e pescoço. A ausência de vasos receptores é um desafio e o cirurgião plástico deve recorrer a outros recursos para solucioná-lo.

\subsection{Alternativas em Situações com Ausência de Vasos Receptores Cervicais}

Várias alternativas foram descritas para levar pedículos vasculares adequados ao pescoço com ausência de vasos receptores. ${ }^{1,11,16}$ Mobilizam-se vasos que não foram comprometidos pela radioterapia ou pelas dissecações cervicais. Hanasono et al descreveu um algoritmo em que utiliza o pedículo da artéria cervical transversa, transferência da veia cefálica do membro superior associado ao uso do pedículo toracoacromial, ${ }^{17}$ e os vasos torácicos internos como receptores. ${ }^{8}$ Os vasos temporais superficiais e o pescoço contralateral não dissecado foram considerados fonte reserva confiável para suprimento vascular. ${ }^{9,18}$ Alças arteriovenosas imediatas ou tardias também foram utilizadas para levar vascularização à região cervical. ${ }^{19}$ Além destes novos pedículos receptores, outras táticas foram descritas para utilizar pedículos mais longos nos retalhos livres ou até alongá-los com o uso de enxerto venoso. Okazaki et al descreveu sua preferência pelos retalhos com pedículos mais longos do reto abdominal e grande dorsal em casos secundários. ${ }^{15}$ Jacobson et al utiliza o retalho escapular toracodorsal de fluxo reverso para situações em que é necessária reconstrução osteomiocutânea. ${ }^{20}$

O pedículo da artéria torácica interna foi utilizado como receptor para reconstrução esofágica com jejuno em 1947 por Longmire et al ${ }^{21}$ e posteriormente para reconstrução mamária por Harashina et al em $1980^{22}$ e Shaw et al em $1983 .^{23}$

Em reconstruções de cabeça e pescoço onde não há vasos receptores cervicais o uso dos vasos torácicos internos tornou-se uma alternativa para receber retalhos livres. A primeira descrição é de Urban et al, em 2006, para reconstrução de hipofaringe com retalho livre antebraquial radial. ${ }^{24}$ Posteriormente, Yagi et al, em 2007, descreveu cinco pacientes em que transplantou omento em série para um segundo retalho livre. ${ }^{25} \mathrm{~A}$ versatilidade deste pedículo também permite sua utilização para reconstruções pediculadas, e foi considerado por Hurvitz et al uma fonte de tecido vascularizado em situações onde não há vasos na região cervical. ${ }^{7}$ 
No entanto, uso dos vasos torácicos internos iniciou-se no campo das reconstruções mamárias e torácicas. O conceito de perfurantes descrito por Koshima et al em 1989 para o pedículo da artéria epigástrica inferior ${ }^{26}$ foi utilizado para os vasos perfurantes oriundos da torácica interna. Kalender et al, em 2000, publicou o uso de um retalho baseado nas perfurantes da artéria mamária interna (IMAP) para reconstrução de mama com sequela de queimadura. ${ }^{27} \mathrm{Um}$ ano depois, Schoeller et al publicou um retalho de mama bipartido para reconstrução pós ressecção oncológica. ${ }^{28}$ Desde então, o serviço de Cirurgia Plástica do HCFMUSP tem desenvolvido linhas de pesquisa em retalhos perfurantes e pedículos receptores. Em 2004, Munhoz et al estudou a anatomia dos vasos perfurantes da artéria torácica interna em 16 dissecações em cadáver, utilizando-se deste conhecimento para reconstrução mamária em 36 pacientes. ${ }^{29}$

Yu et al, em 2006, foi o primeiro a descrever o uso de retalhos em ilha pediculados de IMAP em dois casos para reconstrução de traqueostoma e pescoço anterior. ${ }^{30}$ Foi seguido pela descrição de Vesely et al e Neligan et al de outros dois pacientes com reconstrução de pescoço anterior pelo retalho IMAP como alternativa ao retalho deltopeitoral. ${ }^{31,32}$ Estes últimos foram os primeiros autores a ligar distalmente o pedículo da artéria torácica interna para permitir maior mobilidade e ampliar o arco de rotação do retalho até o pescoço superior. Outros trabalhos demonstraram o uso dos retalhos pediculados IMAP para reconstrução cervical, mas ainda com alcance limitado ao pescoço superior, sem alcançar a face e sem conter tecido ósseo vascularizado. ${ }^{33-35}$

O entendimento da anatomia dos vasos torácicos internos, seus ramos e suas anastomoses permite ampliar as possibilidades de retalhos baseados neste pedículo.

\subsection{Anatomia da Artéria Torácica Interna, suas ramificações e perfurantes}

A artéria torácica interna tem origem usual na artéria subclávia, mas eventualmente pode apresentar origem comum no tronco tireocervical, artérias escapular e tireóidea ou tronco costocervical. Apresenta trajetória ventral descendente no tronco, com distância variável de 11 a 15 mm da margem lateral do 
esterno. Localiza-se superficialmente à pleura parietal, encostando na face posterior das sincondroses costoesternais. Seguindo em direção inferior, situa-se entre os músculos transverso torácico e intercostais internos a partir da região caudal ao $3^{\circ}$ espaço intercostal (EIC). A artéria torácica interna emite ramos para cada espaço intercostal, as artérias intercostais, que percorrem trajeto justaposto às margens inferior e superior de cada arco costal. Entre o $6^{\circ}$ e $7^{\circ}$ EIC divide-se em artérias musculofrênica e epigástrica profunda superior (DSEA). ${ }^{32,36} \mathrm{~A}$ artéria epigástrica profunda superior, em seu percurso caudal, penetra no músculo reto abdominal e divide-se em 2 a 3 ramos principais que se comunicam através de conexões tipo "choke vessels" com a artéria epigástrica profunda inferior e com as artérias intercostais no ventre do músculo reto abdominal. A artéria epigástrica profunda inferior tem origem na artéria ilíaca externa, formando uma via de comunicação na parede anterior do tronco entre as artérias subclávia e ilíaca. ${ }^{37}$

A artéria torácica interna é usualmente acompanhada de duas veias comitantes, que unem-se entre o $2^{\circ}, 3^{\circ}$ ou $4^{\circ} \mathrm{EIC}$, resultando em uma única veia comitante cranial a este nível, em posição medial em relação à artéria, que drena para a veia braquiocefálica. ${ }^{36} \mathrm{~A}$ artéria tem calibre de 1 a $2 \mathrm{~mm}$ no $4^{\circ} \mathrm{EIC}$ e a veia comitante apresenta cerca de 2 a $3 \mathrm{~mm}$. A artéria torácica interna tende a ser mais calibrosa à direita. ${ }^{32,36} \mathrm{O}$ arcabouço costal coalesce através de sincondroses para formar um bloco cartilaginoso comum a partir do sexto arco costal na junção costoesternal, incluindo sétimo e oitavo arcos. Os vasos torácicos estão aderidos à face posterior deste bloco por fáscias musculares até emergirem na margem inferior do oitavo arco, e posicionarem-se na face posterior do ventre do músculo reto abdominal. ${ }^{32,38}$

Os vasos torácicos internos emitem perfurantes cutâneas cujo pedículo é composto por uma artéria, duas veias e o ramo cutâneo anterior do nervo intercostal, que origina-se posteriormente na medula espinhal. O pedículo atravessa os músculos intercostais e o músculo peitoral para irrigar a pele de maneira segmentar, com orientação transversal no tórax anterior. Existem perfurantes descritas nos primeiros seis espaços intercostais, no entanto há variação em relação ao tamanho e dominância. Em geral a perfurante do $2^{\circ} \mathrm{EIC}$ tende a ser maior, mas em mulheres as do $3^{\circ}$ e $4^{\circ}$ EIC também são calibrosas, com participação na irrigação da mama. $^{32,37,38}$ 
No abdome superior, imediatamente abaixo da margem costal, surgem as perfurantes da DSEA, na intersecção tendinosa entre músculo reto abdominal e músculos obliquo externo, interno e transverso do abdome. A perfurantes atravessam o músculo reto abdominal para irrigar a pele sobrejacente. A primeira destas perfurantes geralmente é calibrosa e nomeada artéria epigástrica superior superficial (SSEA). ${ }^{37}$

1.4. Aplicabilidade dos Retalhos Pediculados na Artéria Torácica Interna em Reconstruções de Cabeça e Pescoço

As reconstruções em cabeça e pescoço para defeitos compostos extensos após dissecação cervical e radioterapia são mais complexas e muitas vezes necessitam retalhos combinados para atingir melhora funcional e estética. ${ }^{11} \mathrm{O}$ padrão-ouro para reconstrução mandibular e de outros defeitos ósseos, como maxilectomias, é com retalhos ósseos vascularizados, sejam eles, fibular, escapular, crista ilíaca ou radial antebraquial ${ }^{39}$; sendo necessário associar outros retalhos livres ou retalhos locais a depender da extensão do defeito de partes moles. ${ }^{11-13,40} \mathrm{~A}$ costela já foi utilizada para reconstrução em cabeça e pescoço, seja como enxerto não vascularizado, seja como parte de um retalho que não engloba sua vascularização intrínseca pelos vasos intercostais, como o retalho peitoral com costela. ${ }^{41,42}$ No campo da neurocirurgia e cirurgia ortopédica, o uso de retalho de costela vascularizado e pediculado nos ramos intercostais posteriores permite osteotomias para reconstruções de coluna vertebral e porção proximal do úmero. ${ }^{43,44}$

A intricada rede anastomótica dos vasos torácicos internos permite obter um retalho combinado quimérico com músculo, osso e pele em grande quantidade, sem necessidade de anastomoses microcirúrgicas entre retalhos distintos, e com área doadora única. A continuação da artéria torácica interna consiste em uma bifurcação que gera a artéria epigástrica superior profunda (DSEA), responsável pela irrigação cranial do músculo reto abdominal e a pele suprajacente; e as artérias musculofrênica e costomarginal, estas, responsáveis pela irrigação dos arcos costais inferiores através das suas ramificações em artérias intercostais anteriores. Miller et al descreveu as conexões entre os vasos intercostais e o sistema da DSEA. ${ }^{45}$ 
Caudal à margem costal, bilateralmente, Taylor et al descreve uma perfurante cutânea chamada artéria epigástrica superior superficial, ${ }^{37}$ que irriga 0 abdome superior e apresenta extensões para o lado contralateral. ${ }^{38,46}$ Não há mudança no calibre dos vasos intercostais ao longo do seu percurso entre a artéria torácica interna e a aorta, e eles nutrem os arcos costais com fluxo semelhante tanto pela via anterior quanto pela posterior, respectivamente. ${ }^{37}$ Davison et al descreveu o uso de um retalho livre combinado de fluxo retrógrado, baseado na artéria epigástrica inferior profunda (DIEA), com músculo reto abdominal, pele suprajacente e os arcos costais inferiores, para reconstrução microcirúrgica de defeitos complexos em face. ${ }^{47}$

Em 1971, Strauch et al descreveu em cães a transferência de costela e pele sobrejacente pediculados na torácica interna. Dos sete cães que foram submetidos a esternotomia, 4 morreram de pneumonia nos primeiros 5 dias e os outros 3 tiveram deiscência da ferida esternal. No entanto, o autor demonstrou a possibilidade de um retalho composto contendo osso, músculo e pele com pedículo de 15 a $20 \mathrm{~cm}$ em cães, que pode ser transferido para uso em humanos dada a correlação anatômica. Ele também realizou a primeira dissecação em cadáver com isolamento e rotação do pedículo torácico interno até a margem mandibular. ${ }^{48}$

A primeira transferência de costela para reconstrução em cabeça e pescoço pediculada nos vasos torácicos internos foi descrita por Ketchum et al em 1974. Ele realizou esternotomia e fratura das sincondroses do $1^{\circ}$ ao $6^{\circ}$ arcos costais para obtenção do sétimo arco costal para reconstrução mandibular em uma paciente de 37 anos, vítima de ferimento por arma de fogo. ${ }^{49}$ Posteriormente, Ariyan et al demonstrou a confiabilidade da vascularização costal pela via anterior, através dos vasos intercostais oriundos da torácica interna. Ele descreveu uma reconstrução mandibular microcirúrgica com retalho costal livre por vascularização anterior. ${ }^{50} \mathrm{Em}$ 1988, Cook et al relatou 2 casos de reconstrução de mandíbula com quinta costela pediculada através de esternotomia; ${ }^{51} \mathrm{e}$, em 1995, Arons et al usou um retalho osteomiocutâneo com sexta costela e porção miocutânea do reto superior baseado em pedículo único da torácica interna para reconstrução mandibular. Este retalho foi realizado em 2 tempos por congestão venosa inicial. ${ }^{52}$

Nos últimos quase 20 anos, o uso da costela vascularizada para reconstruções de cabeça e pescoço foi praticamente abandonado. Não há muitas alternativas para pacientes que necessitem reconstruções complexas secundárias e terciárias de cabeça e pescoço, principalmente quando não há vasos receptores 
cervicais adequados e outras reconstruções já foram tentadas em uma área previamente dissecada e irradiada. Nestas condições, realizamos um estudo anatômico para avaliar a possibilidade de uso, e padronizar a técnica de dissecação, de um retalho osteomiocutâneo pediculado nos vasos torácicos internos para reconstruções complexas secundárias e terciárias em cabeça e pescoço.

\subsection{Correlação Anátomo-Clínica no Uso dos Retalhos Pediculados na Artéria Torácica Interna}

A dissecação da artéria torácica interna por esternotomia é dominada por cirurgiões cardíacos há mais de 40 anos. ${ }^{53-55} \mathrm{O}$ acesso a este pedículo por via paraesternal foi primeiramente descrito por Shaw et al em $1983^{23}$ e depois reproduzido nas reconstruções mamárias. ${ }^{29} \mathrm{O}$ isolamento do pedículo torácico interno por via paraesternal, através de janelas transcartilaginosas, ${ }^{49,51}$ ou através de esternotomia em "L invertido", ${ }^{56}$ permite acesso às ramificações vasculares e associação de tecidos para obtenção de um retalho combinado ostemiocutâneo de pedículo estendido. Na verdade, o pedículo corresponde à própria extensão da artéria torácica interna do indivíduo e das veias comitantes. Sua rotação cranial leva um retalho combinado para a região cefálica capaz de reconstruir defeitos complexos cervicofaciais e cranianos sem a necessidade de transplante microcirúrgico. $O$ acesso transcartilaginoso com ressecção e reposicionamento costal e esternal é utilizado na técnica de Ravitch para correção de pectus carinatum e excavatum com índice de complicações aceitável. ${ }^{57-59}$ Como cada ramificação dos vasos torácicos internos, sejam elas a DSEA, a artéria musculofrênica, a SSEA e os vasos intercostais, irriga um tecido específico, músculo reto abdominal, pele e costelas respectivamente; há grande mobilidade entre os componentes do retalho combinado osteomiocutâneo. Isto confere versatilidade e dinamismo às reconstruções em situações de pescoço com ausência de vasos receptores. 
2. Objetivos 
Os objetivos do presente estudo são:

1. Descrever a anatomia da artéria torácica interna com seus ramos e respectivos territórios vasculares para realizar retalhos osteomiocutâneos combinados pediculados neste vaso, em cadáveres.

2. Verificar o arco de rotação do retalho osteomiocutâneo combinado baseado na artéria torácica interna e as possibilidades de reconstrução na região cefálica e cervical.

3. Avaliar a aplicabilidade clínica de reconstruções terciárias em cabeça e pescoço com o retalho osteomiocutâneo pediculado da artéria torácica interna. 
3. Método 


\subsection{Estudo anatômico}

Dissecação de 35 (trinta e cinco) cadáveres no Serviço de Verificação de Óbitos da Capital, SVOC-USP, para identificação dos retalhos da artéria torácica interna em número suficiente para padronização da técnica conforme pré-requisitos da instituição.

A técnica de dissecação baseou-se nos estudos experimentais prévios de dissecação em cadáver da própria Disciplina de Cirurgia Plástica e Queimaduras do HCFMUSP e que consistiram no estudo dos territórios vasculares e de alcance de retalhos. O objetivo da pesquisa foi determinar exatamente as possibilidades de composição, alcance e dissecação cirúrgica do novo retalho proposto, em cadáveres, para a posterior utilização clínica. 


\section{Técnica:}

Com o cadáver em decúbito dorsal horizontal são demarcados os reparos anatômicos para direcionamento da dissecação (Fig. 1).

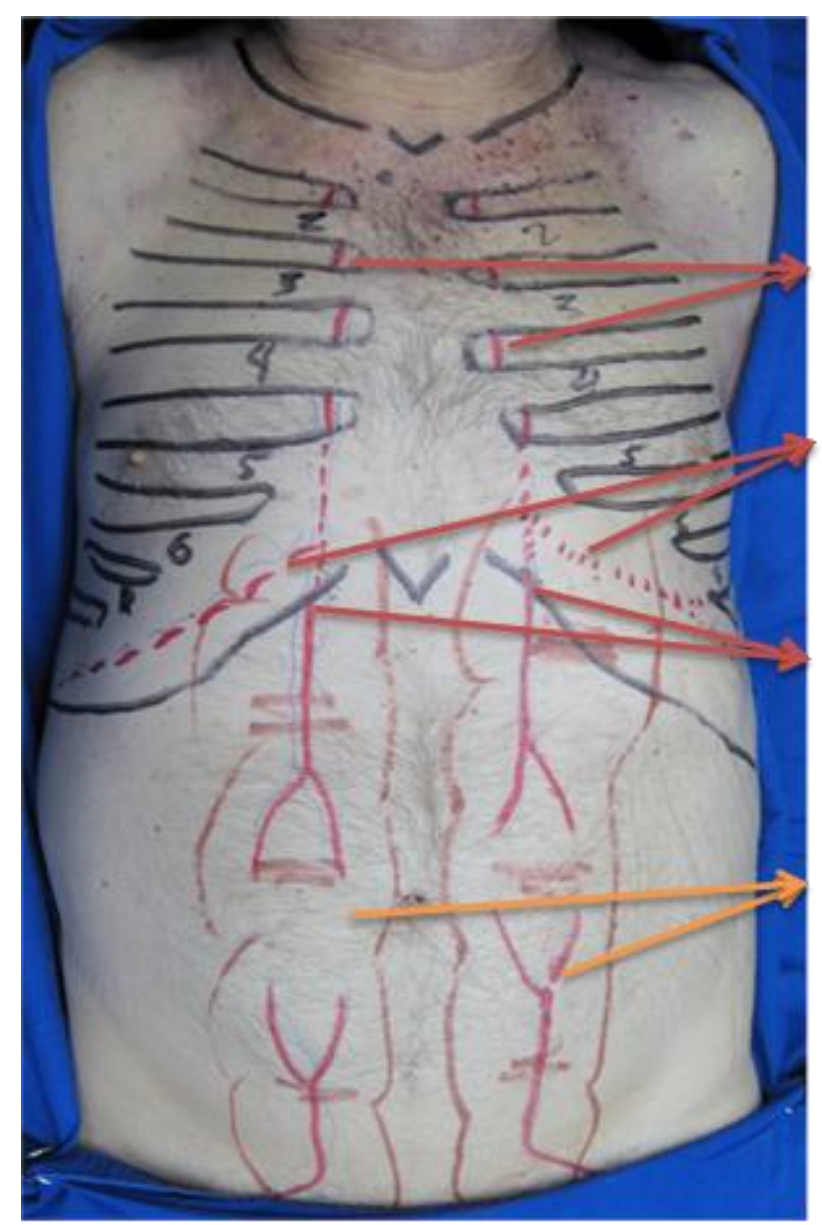

Vasos Torácicos

Internos

Vasos Musculofrênicos

Vasos Epigástricos

Superiores Profundos

Músculos Retos

Abdominais

Figura 1: Vista anterior do tórax e abdome. Desenho das costelas numeradas e da margem costal inferior em preto. Desenho dos músculos retos abdominais em marrom e do pedículo torácico interno que se continua com os vasos epigástricos profundos superiores. 
Realiza-se incisão mediana manúbrio-púbica com descolamento suprafascial do tecido celular subcutâneo bilateralmente, com extensão lateral até linha axilar anterior. Levantamento dos músculos peitorais maiores a partir de suas inserções esternais mediais e isolamento dos músculos retos abdominais através de incisão retangular longitudinal bilateral na aponeurose anterior, com descolamento da aponeurose posterior para identificação do pedículo DSEA (Fig. 2).

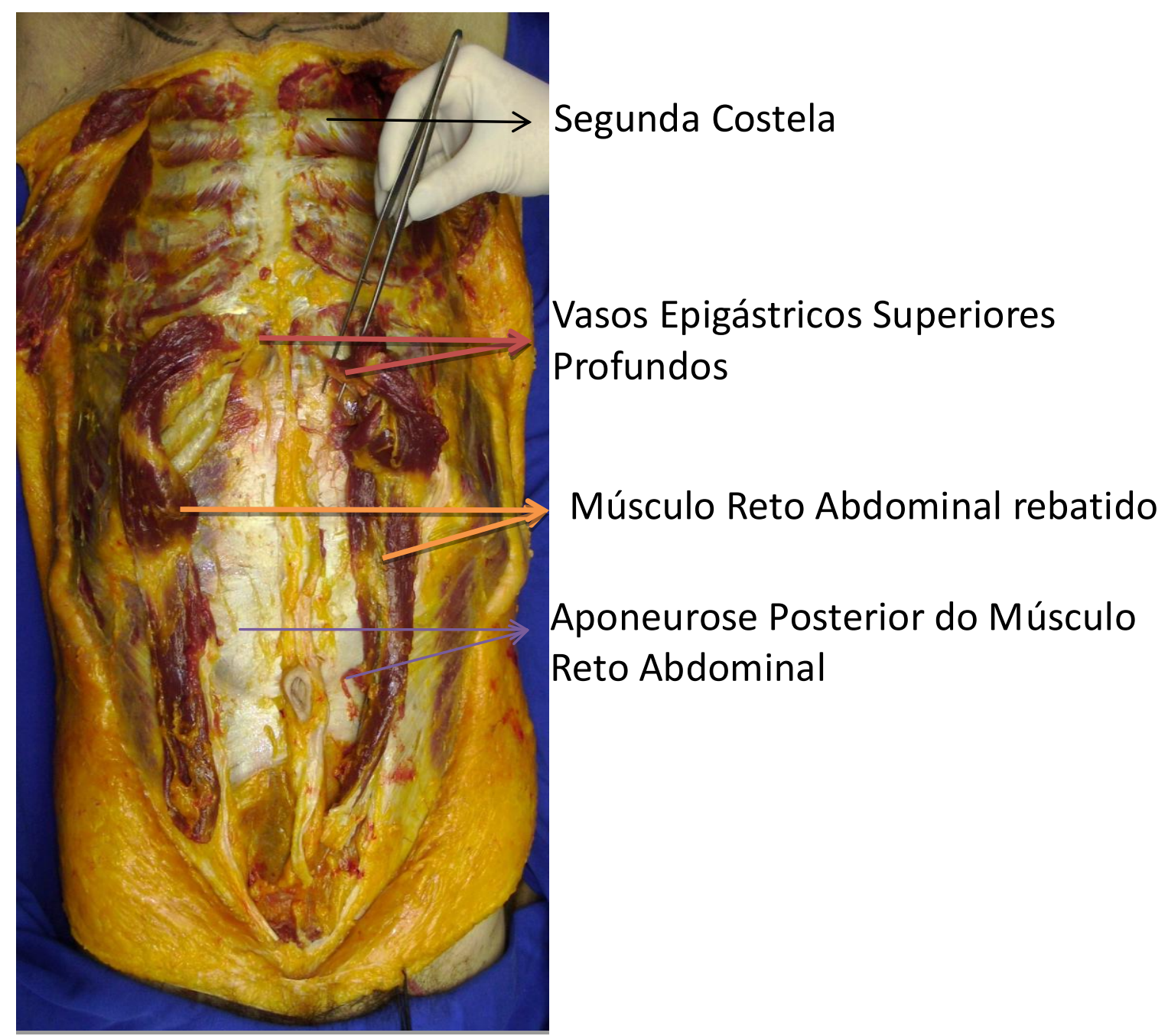

Figura 2: Vista anterior do tórax e abdome após dissecação subcutânea até linha axilar anterior. Levantados músculos peitorais maiores para expor arcos costais. Os músculos retos abdominais foram levantados e rebatidos com exposição dos vasos epigástricos profundos superiores logo após emergirem abaixo da margem inferior do gradeado costal, antes de entrarem nos músculos. Aponeurose posterior dos retos abdominais evidenciada na região mediana do abdome em cor branca inacarada. 
Ressecção dos músculos intercostais no segundo EIC na região paraesternal para acesso ao pedículo da artéria torácica interna no espaço pré-pleural. Cateterização da artéria torácica interna para injeção de contraste aquoso conforme técnica descrita nos trabalhos de Munhoz, Vesely e Schmidt. ${ }^{29,32,60}$ (Fig 3).
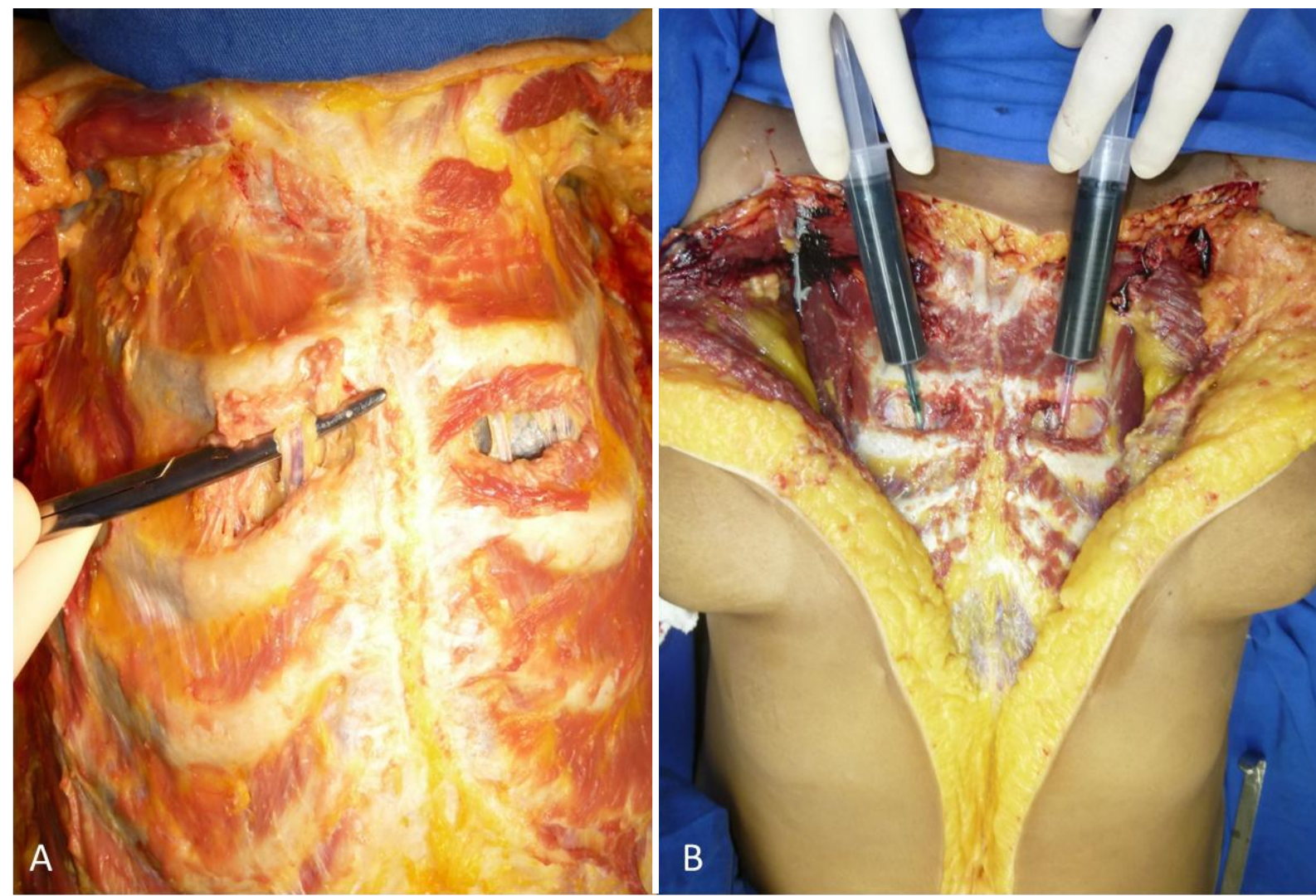

Figura 3: Vista anterior do arcabouço costal com ressecção da musculatura peitoral maior e intercostal do $2^{\circ}$ EIC para acesso ao pedículo torácico interno A: Pedículo isolado envolvendo a tesoura à direta e repousando sobre pleura parietal e pulmão à esquerda. Os músculos peitorais maiores foram rebatidos bilateralmente B: Cateterização e injeção de contraste aquoso nas artérias torácicas internas. Porção cranial do cadáver no topo da figura. 
A identificação e isolamento de toda extensão dos vasos torácicos internos é através de ressecção das sincondroses e cartilagens costais da $2^{a}$ à $4^{a}$ costelas, com posterior isolamento da bifurcação dos vasos torácicos internos em vasos musculofrênicos e epigástricos superiores profundos em sua topografia retrocostal e pré-pleural, entre a sincondrose do $5^{\circ}, 6^{\circ}$ e $7^{\circ}$ arcos e o músculo transverso do tórax. A partir do pedículo torácico interno e dos vasos musculofrênicos ramificam-se os vasos intercostais que seguirão percurso transversal nas margens inferior $\mathrm{e}$ superior das costelas profundamente às fibras do músculo intercostal interno (Figs. $4,5$ e 6$)$.

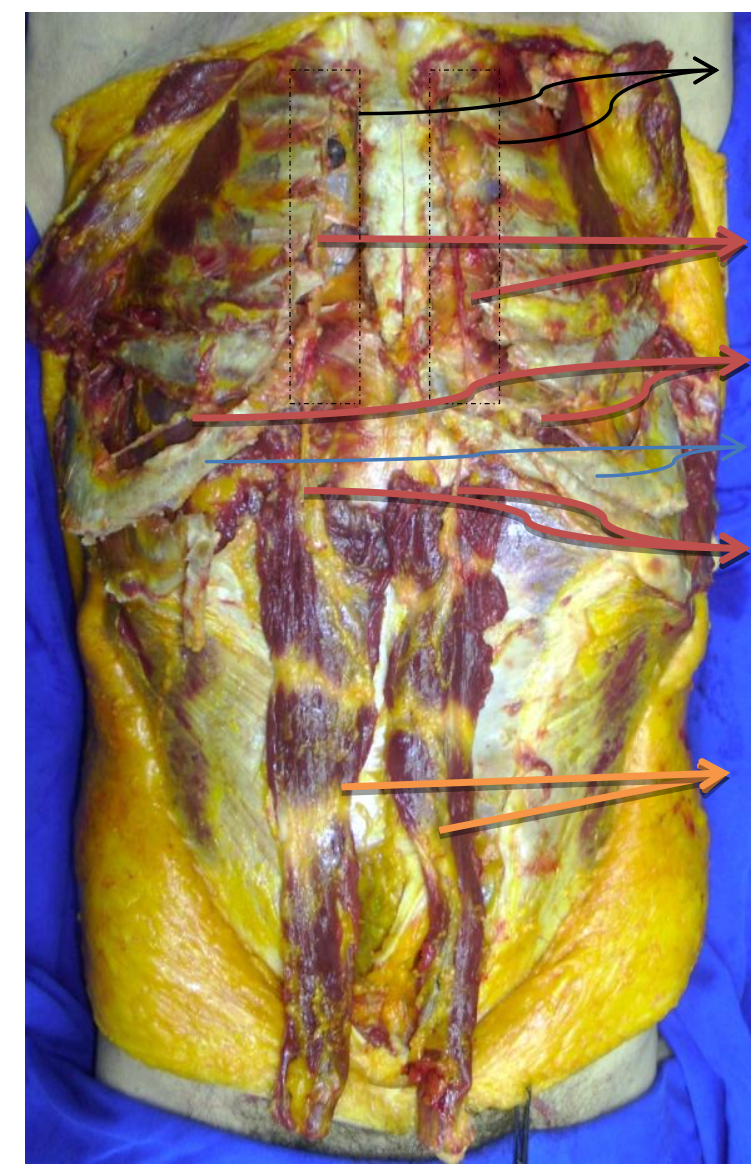

Janela após ressecção arcos costais cartilaginosos

Pedículos Torácicos Internos expostos

Pedículos Musculofrênicos

Sétima Costela

Pedículos Epigástricos

Superiores Profundos

Músculo Reto Abdominal

rebatido

Figura 4: Vista anterior do tórax e abdome após dissecação subcutânea até linha axilar anterior e ressecção dos arcos costais cartilaginosos. É possível acompanhar a continuação dos vasos torácicos internos até sua bifurcação em vasos musculofrênicos e DSEA. Demarcados sétima costela e músculos reto abdominais Caixas tracejadas: Janela prépleural para visualizar pedículo torácico interno. 


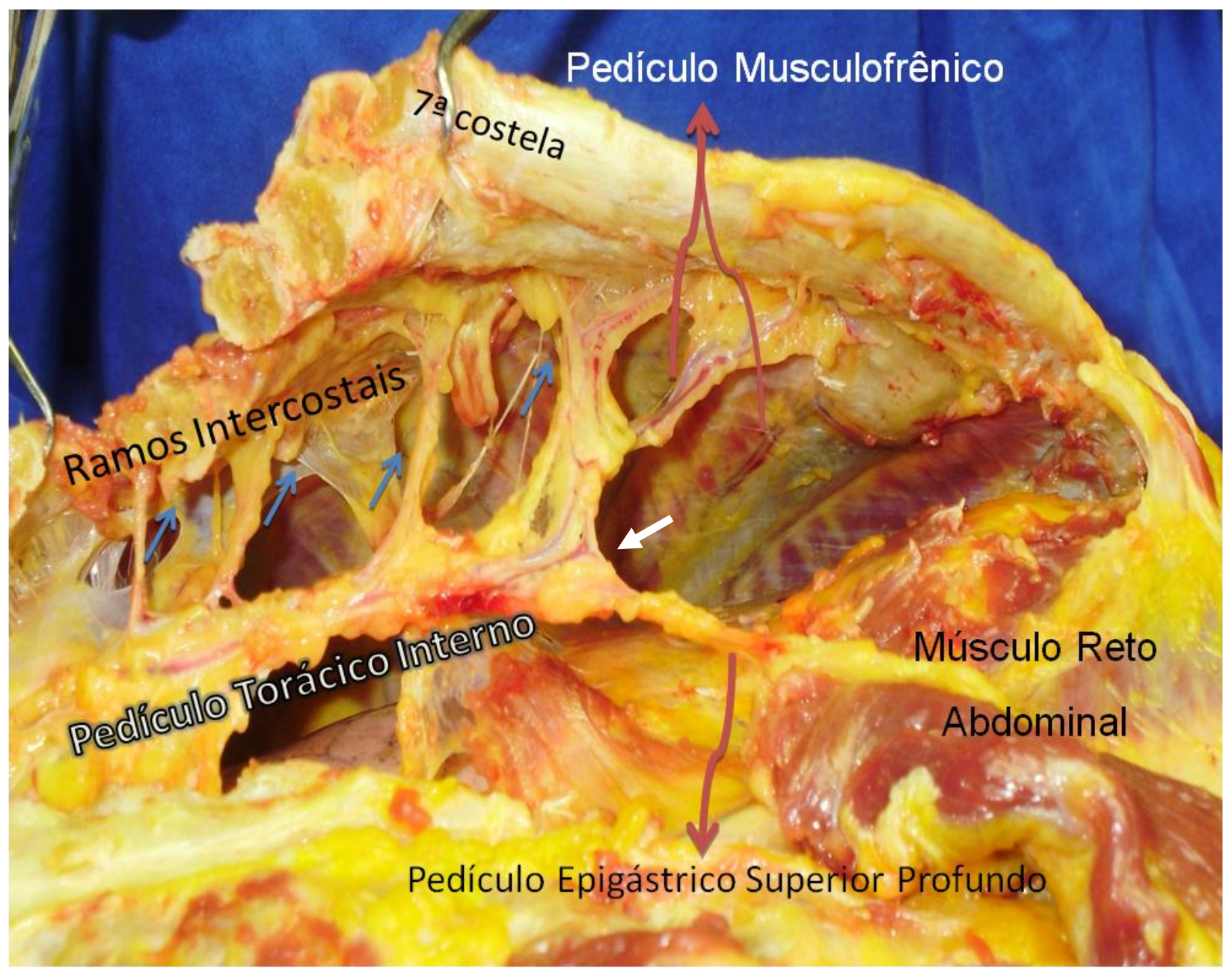

Figura 5: Vista interna da cavidade torácica após ressecção das articulações costoesternais na margem inferior da caixa torácica com porção cranial à esquerda. Após descolamento do pedículo vascular da parede posterior das cartilagens costais e ressecção do músculo transverso do tórax, é possível identificar o pedículo torácico interno e sua bifurcação (seta branca) em vasos musculofrênicos e epigástricos profundos superiores. Cranialmente, antes de bifurcar (lado esquerdo da figura), ele emite os ramos intercostais para $3^{a}, 4^{\underline{a}}, 5^{\underline{a}}$ e $6^{\underline{a}}$ costelas (setas azuis). O músculo reto abdominal e a sétima costela estão identificados. $\mathrm{Na}$ dissecação do retalho osteomiocutâneo pediculado nos vasos torácicos internos, são mantidas as intercostais para sexta e sétima costelas, as demais são ligadas. 


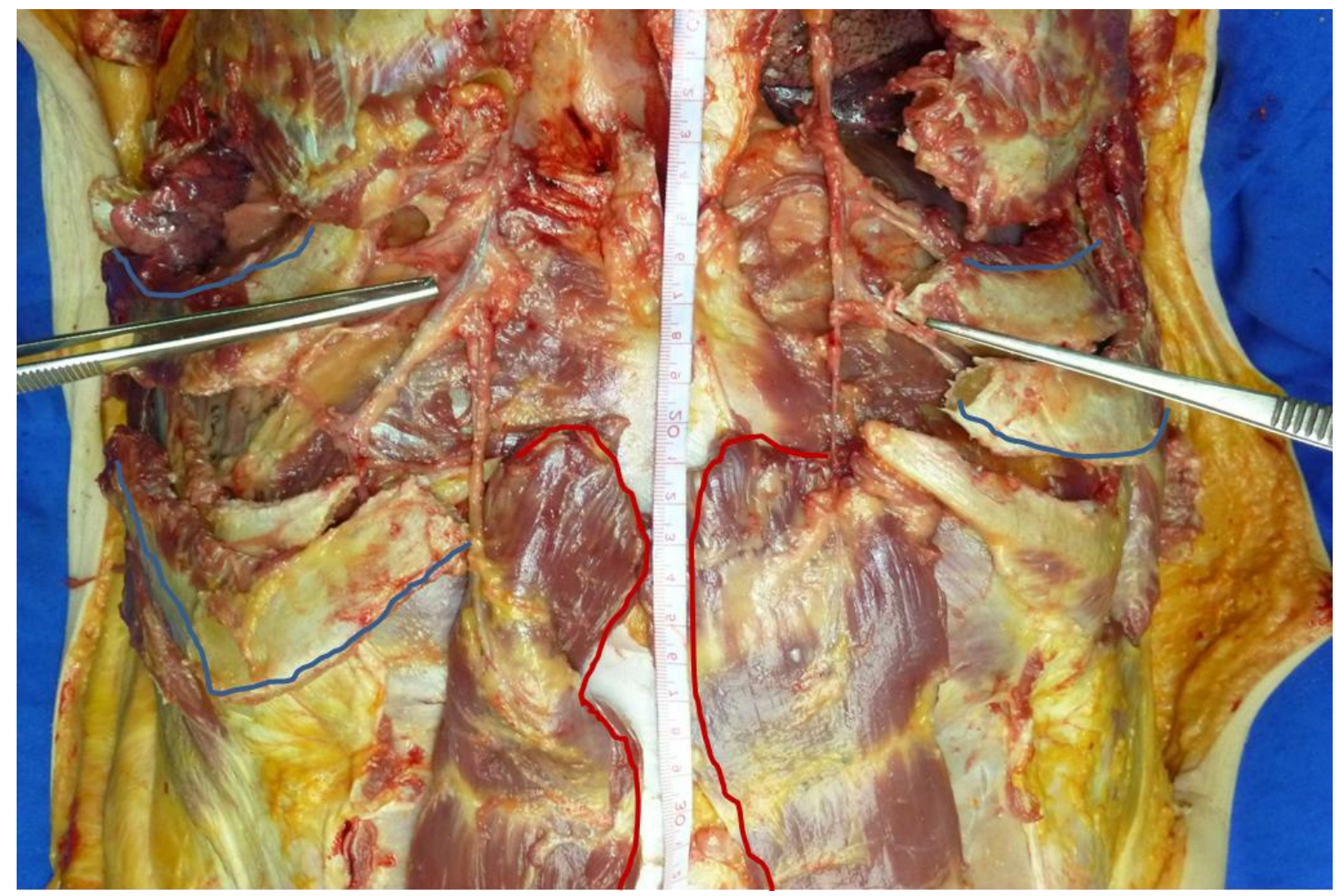

Figura 6: Detalhe da visão anterior da bifurcação dos vasos torácicos internos em vasos epigástricos superiores profundos, que irrigam os músculos retos abdominais e musculofrênicos, que irrigam os arcos costais (apontada na ponta das pinças bilateralmente). A sexta e sétima costelas (linhas azuis) e as porções superiores dos músculos retos abdominais (linhas vermelhas) estão isolados. 
A partir da bifurcação da torácica interna em DSEA e musculofrênica, são identificadas e dissecadas as artérias intercostais para o $6^{\circ}$ e $7^{\circ}$ arcos, bem como a continuação da artéria epigástrica profunda superior no músculo reto abdominal, incluso no retalho, até os vasos epigástricos profundos inferiores (Fig. 7).
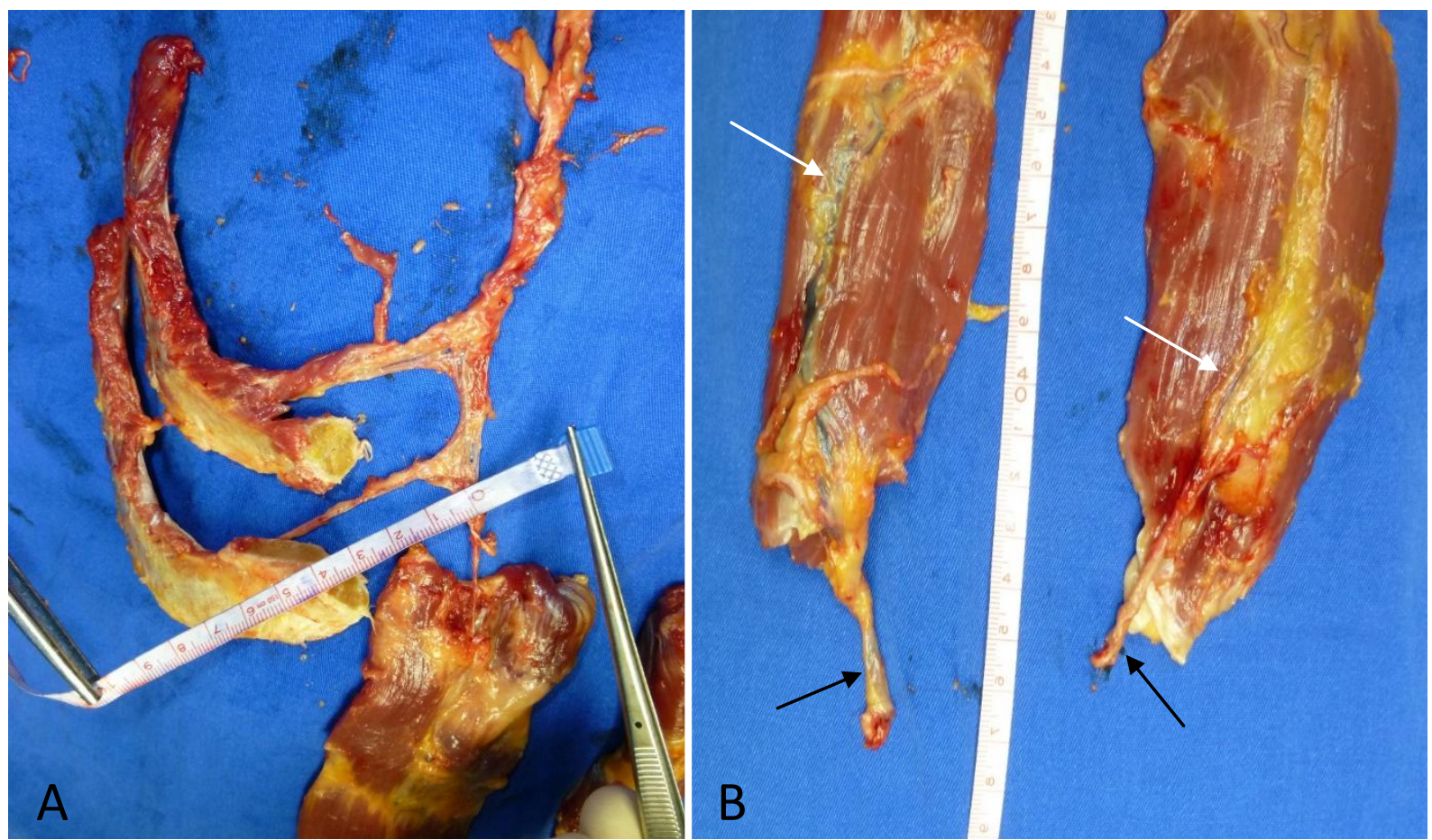

Figura 7: A: Ramificação dos vasos torácicos internos em ramos intercostais, para as costelas; e epigástrico superior profundo, para o reto abdominal. Sexta e sétima costelas estão isoladas com seus respectivos pedículos vasculares. Demonstrada medição do ramo intercostal para a sétima costela. A porção superior do músculo reto abdominal é visível no canto inferior da figura. B: Porção distal dos músculos retos abdominais com pedículo epigástrico inferior profundo correndo no interior do músculo (seta branca) e dissecado na sua porção mais distal após emergir do ventre muscular, logo antes de sua origem nos vasos ilíacos internos (seta negra).

A vascularização do componente miocutâneo associado aos arcos costais ocorre através de vasos perfurantes oriundos dos vasos intercostais, que atravessam músculos peitoral maior, serrátil anterior e oblíquo externo para atingir a pele (Fig. 8). 


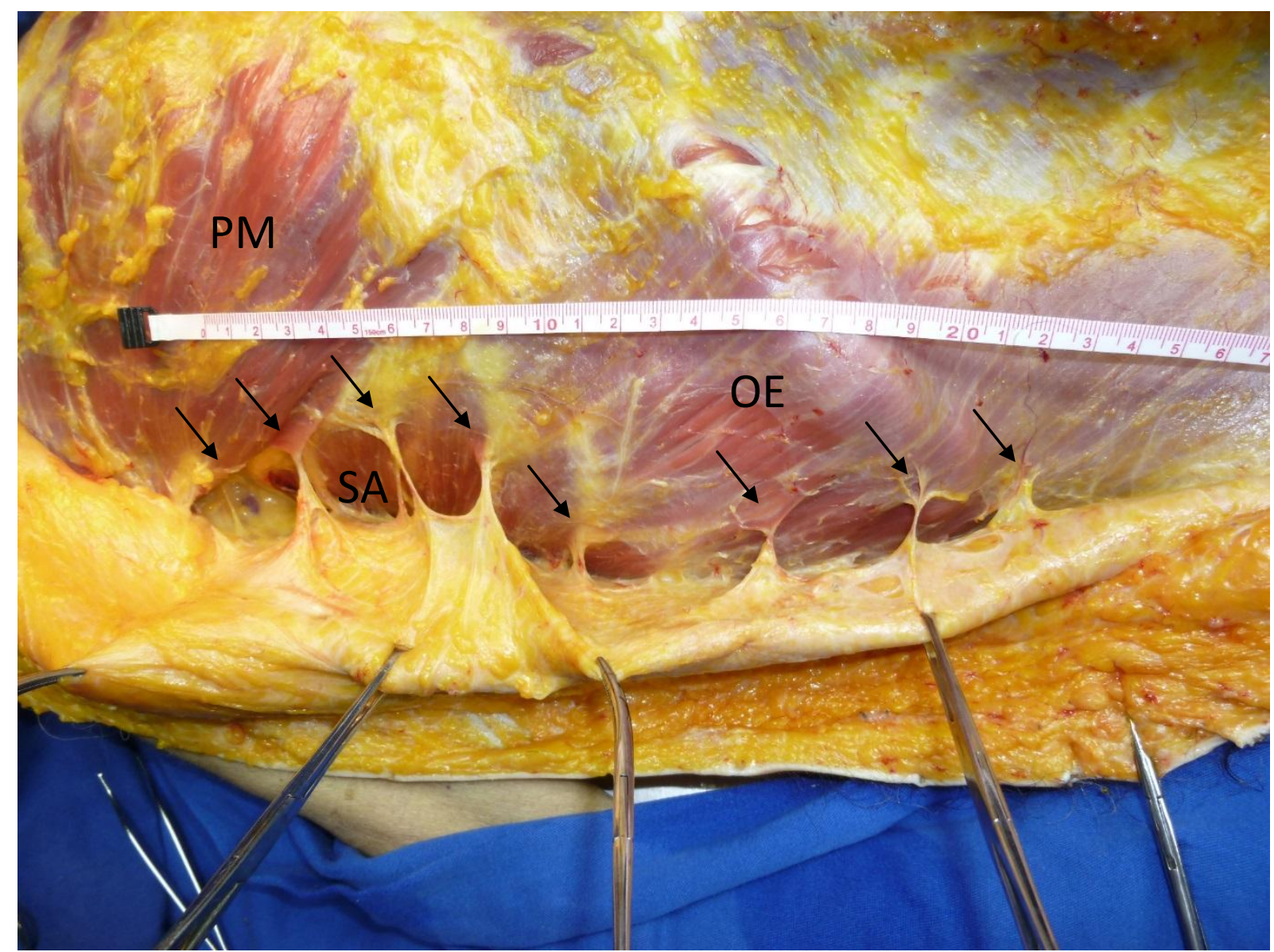

Figura 8: Aspecto anterolateral da região tóraco-abdominal. É possível visualizar as perfurantes dos vasos intercostais (setas negras) emergindo dos músculos peitoral maior (PM), serrátil anterior (SA) e oblíquio externo (OE). Essas perfurantes irrigam o componente cutâneo transversal imediatamente acima das costelas, que fará parte da porção osteomiocutânea do retalho.

Posteriormente, os tecidos pediculados nos vasos torácicos internos são isolados. Procede-se à separação do sexto e sétimo arcos costais e vasos intercostais e musculofrênicos; levantamento do músculo reto abdominal e DSEA; identificação das perfurantes epigástricas superiores superficiais e perfurantes intercostais laterais, com respectivas ilhas de pele. Com o retalho quimérico osteomiocutâneo dissecado bilateralmente, realiza-se a medida das extensões vasculares de cada pedículo e sua distância ao ponto de rotação no primeiro espaço intercostal, na borda inferior da primeira costela (Fig. 9). 


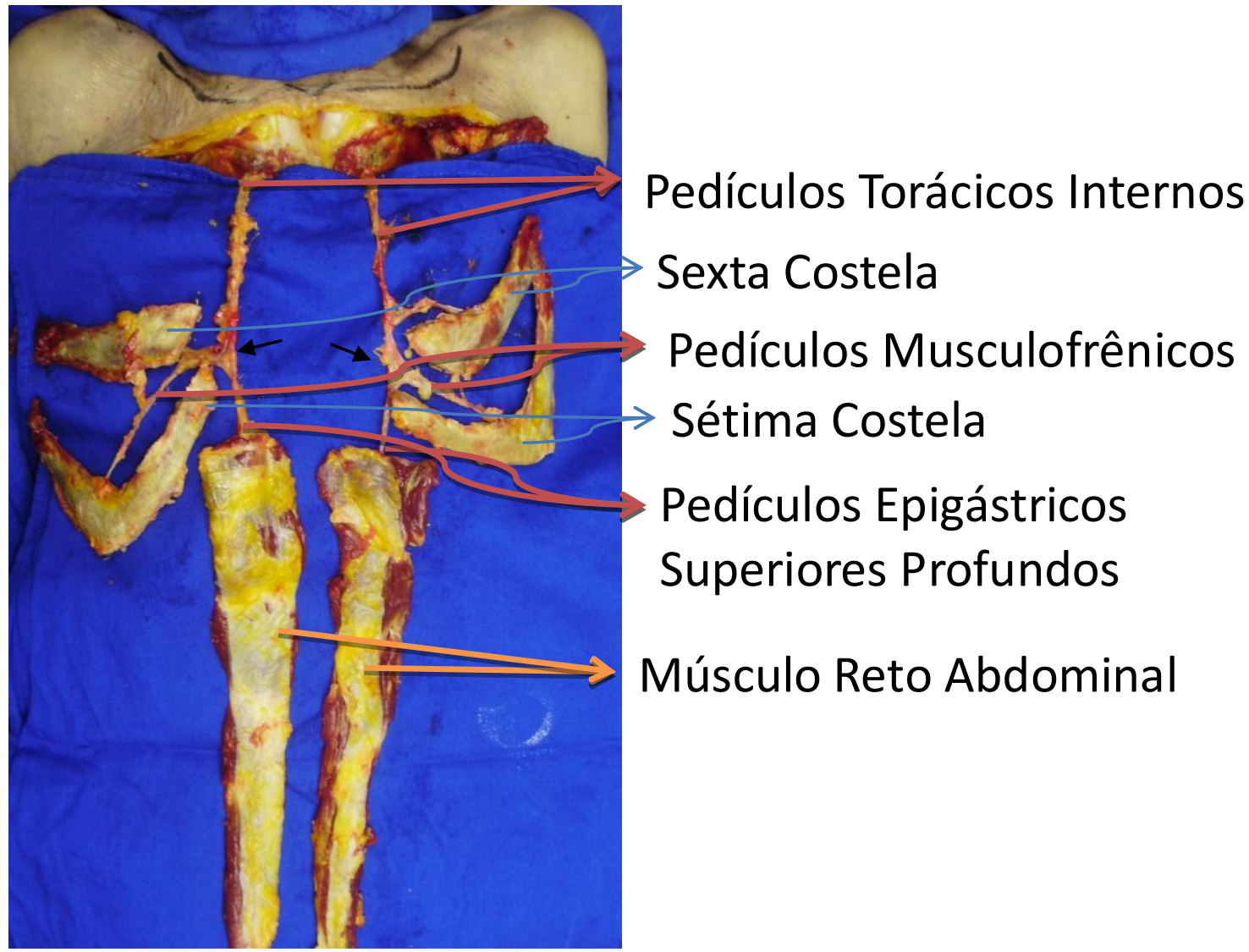

Figura 9: Vista anterior do retalho osteomiocutâneo dissecado bilateralmente. Ele é constituído de sexta e sétima costelas e músculo reto abdominal. O pedículo torácico interno inicia-se superiormente na margem inferior da primeira costela, bifurca-se em vasos musculofrênicos e epigástricos profundos superiores (setas negras). No retalho do lado direito, os ramos intercostais para a sexta e sétima costelas são oriundos da musculofrênica (tipo 1, conforme texto); à esquerda, a sexta costela tem irrigação dupla, por ramo direto da torácica interna e pela musculofrênica (tipo 3). Os pedículos, as costelas e os músculos retos abdominais estão identificados.

A composição final do retalho quimérico consiste em pedículo vascular principal baseado nos vasos torácicos internos, com pedículo secundário musculofrênico e intercostal para o componente osteomiocutâneo costal com $6^{\mathrm{a}}$ e $7^{\mathrm{a}}$ costelas, parte dos músculos peitoral maior, serrátil anterior e pele suprajacente; e outro pedículo secundário epigástrico profundo superior para o componente miocutâneo do músculo reto abdominal e pele suprajacente, até os vasos epigástricos profundos inferiores (Fig. 10). 


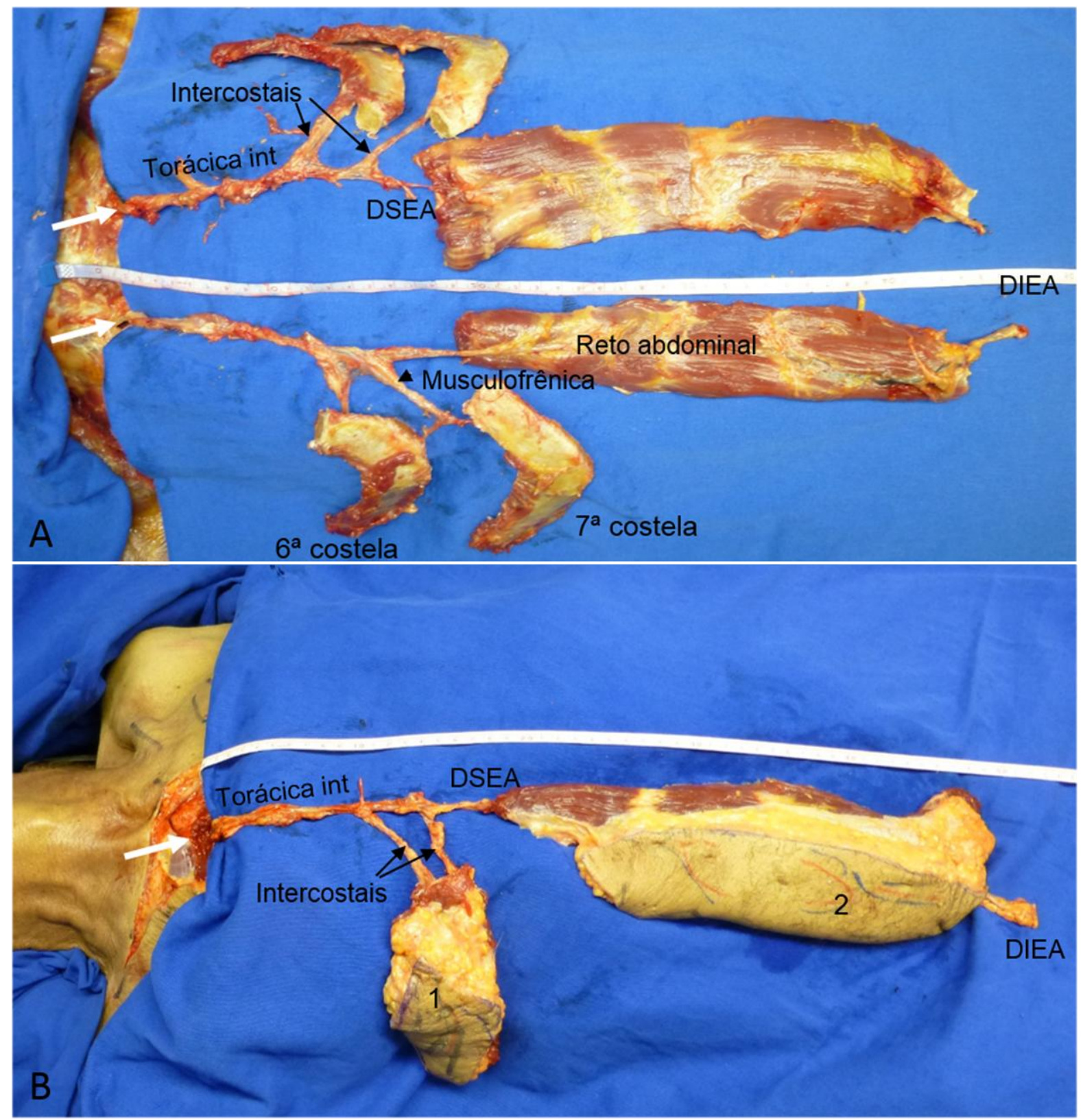

Figura 10: A. Retalho osteomuscular baseado nos vasos torácicos internos dissecado bilateralmente. É possível identificar os vasos torácicos internos emitindo os vasos intercostais e sua bifurcação em DSEA e vasos musculofrênicos O pedículo vascular termina na DIEA, após percorrer todo músculo reto abdominal. A sexta e sétima costelas estão evidentes após ressecção do componente miocutâneo. B. Retalho osteomiocutâneo com $6^{\underline{a}}$ e $7^{\underline{a}}$ costelas (1) e componente miocutâneo do músculo reto abdominal com orientação vertical (2). Os pedículos vasculares estão isolados e identificados. As setas brancas apontam para o ponto pivô do retalho na margem inferior da primeira costela. 
Procede-se à rotação do retalho combinado contendo osso, músculo e pele para a região cefálica e medida do alcance de cada componente às regiões faciais (Fig. 11). Registro fotográfico da dissecação. As medidas foram obtidas com o software Image $\mathrm{A}^{\circ}$, de Research Services Branch, National Mental Health Institute, Bethesda, Maryland, United States of America.
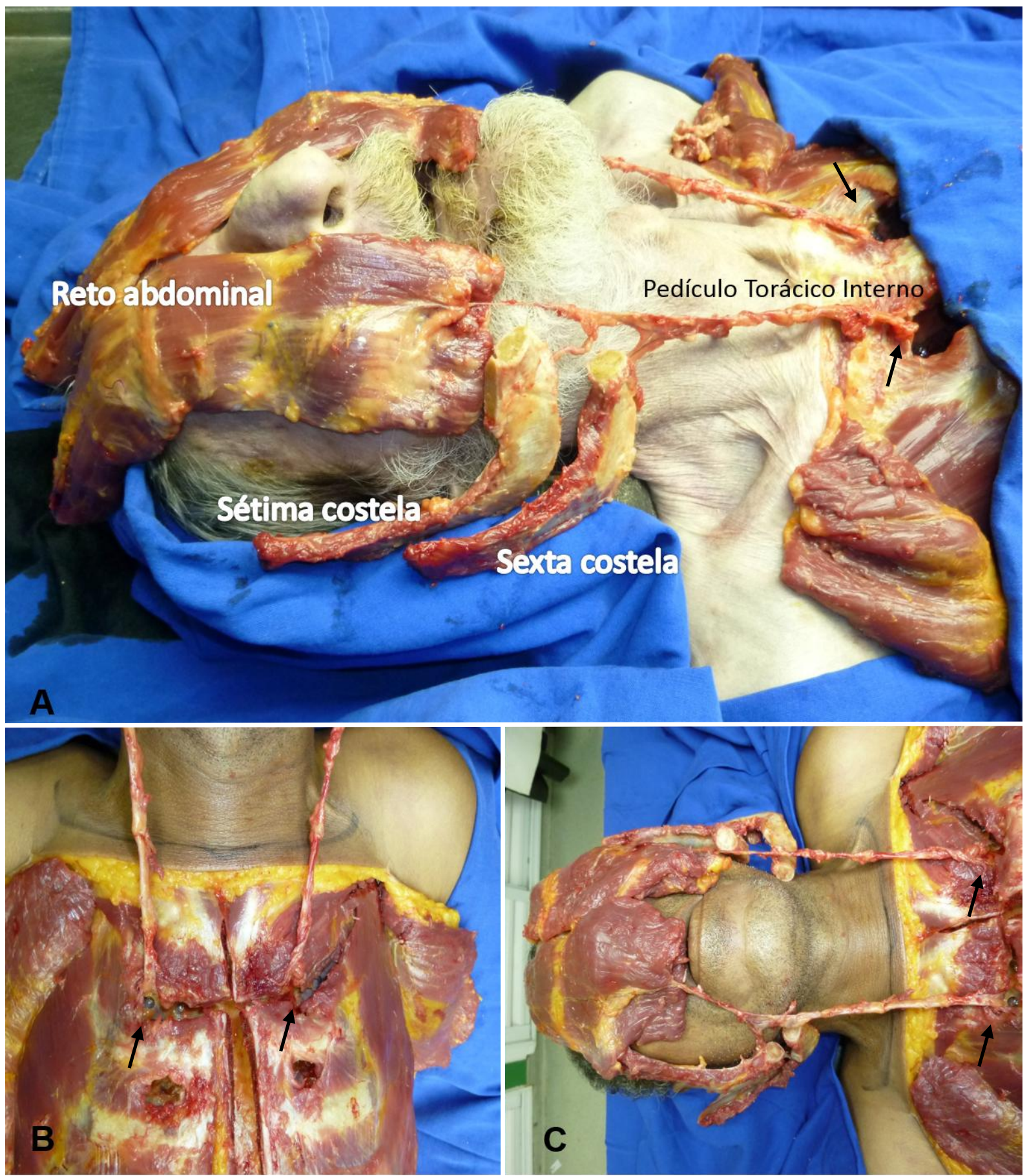

Figura 11: A: Retalho osteomiocutâneo após rotação para o segmento cefálico. O ponto pivô localiza-se na margem inferior da primeira costela (setas negras). É possível visualizar 
toda a extensão dos vasos torácicos internos e sua ramificação para as intercostais da sexta e sétima costelas e seu ramo terminal epigástrico superior profundo, que irriga o músculo reto abdominal. Este vaso epigástrico divide-se dentro do ventre muscular, irrigando-o e enviando perfurantes cutâneas para depois coalescer nos vasos epigástricos profundos inferiores na porção mais caudal do músculo. A extremidade distal do músculo reto abdominal atinge o occipício e carrega os vasos epigástricos inferiores profundos para possível anastomose vascular. Neste exemplo a porção cutânea do retalho sobre o músculo reto abdominal e sobre as costelas foi retirada para melhor visualização dos componentes musculares e ósseos. B: detalhe do ponto pivô na margem inferior da primeira costela. C: Visão anterior dos retalhos rodados para o segmento cefálico. 


\subsection{Análise Estatística}

A normalidade das variáveis foi avaliada com o teste de KolmogorovSmirnov. As variáveis quantitativas foram apresentadas descritivamente em tabelas contendo valores mínimos e máximos, média e desvio padrão. A comparação das médias entre os lados direito e esquerdo foram comparadas com teste t-Student pareado. A comparação das médias entre os sexos foram comparadas com teste tStudent para amostras independentes.

A correlação linear entre idade, peso e altura com as demais medidas, bem como entre elas, foi avaliada com o coeficiente de correlação de Pearson.

A comparação entre as médias das posições D4, D5 e D5' foram avaliadas com análise de variância para medidas repetidas, quando significante, prosseguiu-se à análise com a realização de contraste.

Os valores de $p<0,05$ foram considerados estatisticamente significantes. ${ }^{61}$ 
4. Resultados 


\subsection{Estudo anatômico}

Foram dissecados 35 cadáveres, 26 (74,3\%) do sexo masculino e 9 (25,7\%) do sexo feminino A média de idade dos cadáveres dissecados foi de 62,7 anos, desvio padrão (dp) 13,6 anos; com altura em média de $165 \mathrm{~cm}, \mathrm{dp}=10 \mathrm{~cm}$; e o peso médio foi de $59,7 \mathrm{Kg}, \mathrm{dp}=13,4 \mathrm{Kg}$ (Tabela 1 ).

\begin{tabular}{|l|c|c|c|c|c|}
\hline $\begin{array}{c}\text { Dados } \\
\text { epidemiológicos }\end{array}$ & N & Mínimo & Máximo & Média & $\begin{array}{c}\text { Desvio } \\
\text { padrão }\end{array}$ \\
\hline Idade & 35 & 40 & 91 & 62,65 & 13,55 \\
\hline Altura & 35 & 1,37 & 1,78 & 1,65 & 0,10 \\
\hline Peso & 35 & 35 & 82 & 59,66 & 13,38 \\
\hline
\end{tabular}

Tabela 1: Dados epidemiológicos do estudo anatômico

\subsubsection{Vasos epigástricos superiores superficiais (SSEA)}

Os vasos epigástricos superiores superficiais emergem logo abaixo da margem costal inferior, como ramos perfurantes cutâneos oriundos dos vasos epigástricos superiores profundos. Estas perfurantes atravessam o músculo reto abdominal para irrigar a pele com uma orientação transversal ipsilateral.

Nas trinta e cinco dissecações de cadáver injetou-se contraste aquoso na artéria torácica interna através de janela muscular no $2^{\circ}$ EIC e procedeu-se à dissecação cautelosa das perfurantes cutâneas que emergiam através da aponeurose que recobre o músculo reto abdominal, caudalmente, a partir do processo xifóide.

Inicialmente, acessamos a artéria torácica interna no segundo espaço intercostal. A infusão de corante aquoso intra-arterial facilitou a identificação das perfurantes SSEA, que foram então isoladas, bilateralmente, a partir do apêndice xifóide. Em todas as dissecações, foi possível isolar pelo menos uma perfurante de cada lado com calibre $>0,3 \mathrm{~mm}$ numa distância média de $5 \mathrm{~cm}$ de distância do xifóide no eixo longitudinal e $2,5 \mathrm{~cm}$ no eixo transversal. (Fig. 12) 

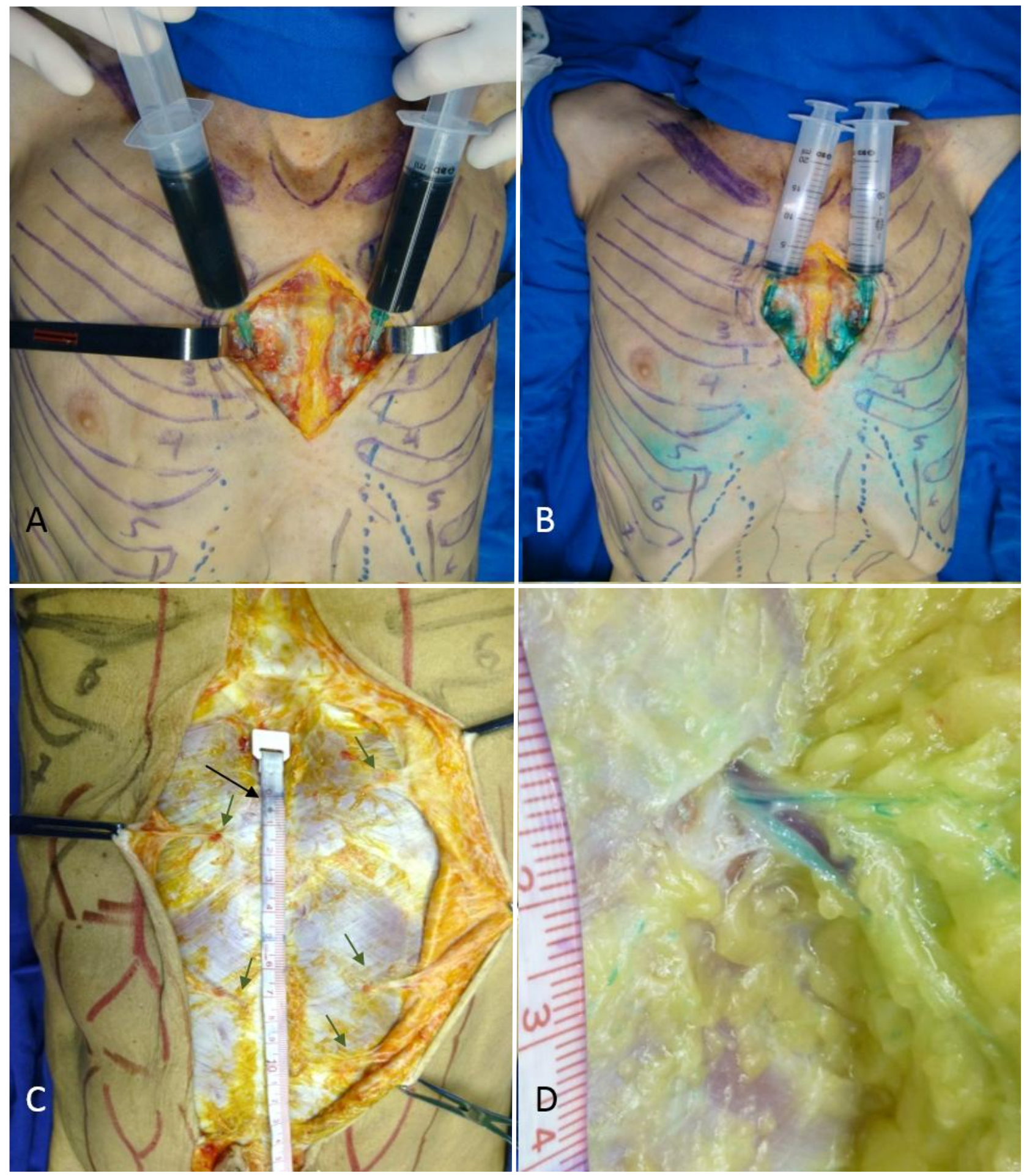

Figura 12: Técnica de identificação das SSEA. A. Injeção de corante aquoso na artéria torácica interna no segundo espaço intercostal. B. Demarcação cutânea com o corante que se difundiu pelas perfurantes oriundas dos vasos torácicos internos. C. Dissecação das perfurantes SSEA (setas verdes) com orientação a partir do apêndice xifóide (seta negra). D. Visão aproximada em detalhe da perfurante SSEA preenchida pelo corante. 
Foram isoladas 114 perfurantes, sendo 38 (33,3\%) em cadáveres do sexo feminino e $76(66,7 \%)$ em cadáveres do sexo masculino.

Do lado direito, foram dissecadas 62 perfurantes, com calibre arterial médio de $0,68 \mathrm{~mm}$ e desvio padrão de $0,31 \mathrm{~mm}$. Os calibres foram homogêneos em relação às 52 perfurantes dissecadas à esquerda. $\mathrm{O}$ calibre mínimo considerado foi de $0,3 \mathrm{~mm}$ e o máximo encontrado, foi de $1,7 \mathrm{~mm}$ para ambos os lados. Houve uma média de 1,8 perfurantes à direita e 1,5 à esquerda por paciente.

Todas as perfurantes foram colocadas em um gráfico de acordo com sua localização em relação ao apêndice xifóide, com eixo x paralelo ao chão e, y, na direção crânio-caudal. Do lado direito, as perfurantes encontravam-se a uma distância média de 4,9 cm $(\mathrm{dp}=3,4 \mathrm{~cm})$ do xifóide no eixo y, e a 2,8 cm $(\mathrm{dp}=1,2 \mathrm{~cm})$, no eixo x. À esquerda, as distâncias das perfurantes no eixo y eram de $4,9 \mathrm{~cm}$ $(\mathrm{dp}=2,7 \mathrm{~cm}), e$, em $x, 2,5 \mathrm{~cm}(\mathrm{dp}=1,3 \mathrm{~cm})$. A tabela 2 discrimina os valores de calibre e localização conforme o lado. A figura 13 ilustra a localização das perfurantes e sua dispersão em relação ao lado, bem como a distribuição de acordo com o calibre. 
De acordo com os calibres, as SSEA foram agrupadas em 4 grupos:

- Grupo 1: 0,3 $\leq$ calibre <0,5 mm;

- Grupo 2: 0,5 $\leq$ calibre $<1,0 \mathrm{~mm}$

- Grupo 3: 1,0 $\leq$ calibre $\leq 1,5 \mathrm{~mm}$

- Grupo 4: calibre $\geq 1,5 \mathrm{~mm}$

O calibre mais frequente das perfurantes SSEA foi encontrado no grupo 2, de 0,5 a 1,0 mm, com 60 (52,7\%) ocorrências.

\begin{tabular}{|l|c|c|c|c|c|}
\hline Perfurantes SSEA & $\mathrm{N}$ & Mínimo & Máximo & Média & $\begin{array}{c}\text { Desvio } \\
\text { padrão }\end{array}$ \\
\hline Calibre - Direita & 62 & $0,3 \mathrm{~mm}$ & $1,7 \mathrm{~mm}$ & $0,68 \mathrm{~mm}$ & 0,31 \\
\hline X - Direita & 62 & $0,9 \mathrm{~cm}$ & $8,5 \mathrm{~cm}$ & $2,75 \mathrm{~cm}$ & 1,22 \\
\hline Y - Direita & 62 & $-0,8 \mathrm{~cm}$ & $13,4 \mathrm{~cm}$ & $4,93 \mathrm{~cm}$ & 3,14 \\
\hline Calibre - Esquerda & 52 & $0,3 \mathrm{~mm}$ & $1,7 \mathrm{~mm}$ & $0,68 \mathrm{~mm}$ & 0,31 \\
\hline X - Esquerda & 52 & $0,3 \mathrm{~cm}$ & $7,4 \mathrm{~cm}$ & $2,52 \mathrm{~cm}$ & 1,32 \\
\hline Y - Esquerda & 52 & $0,1 \mathrm{~cm}$ & $11,8 \mathrm{~cm}$ & $4,96 \mathrm{~cm}$ & 2,67 \\
\hline
\end{tabular}

Tabela 2: Calibre e localização das perfurantes SSEA de acordo com o lado. As variáveis $X$ e $\mathrm{Y}$ foram medidas num plano bidimensional a partir do apêndice xifoide, conforme figura 13 . 


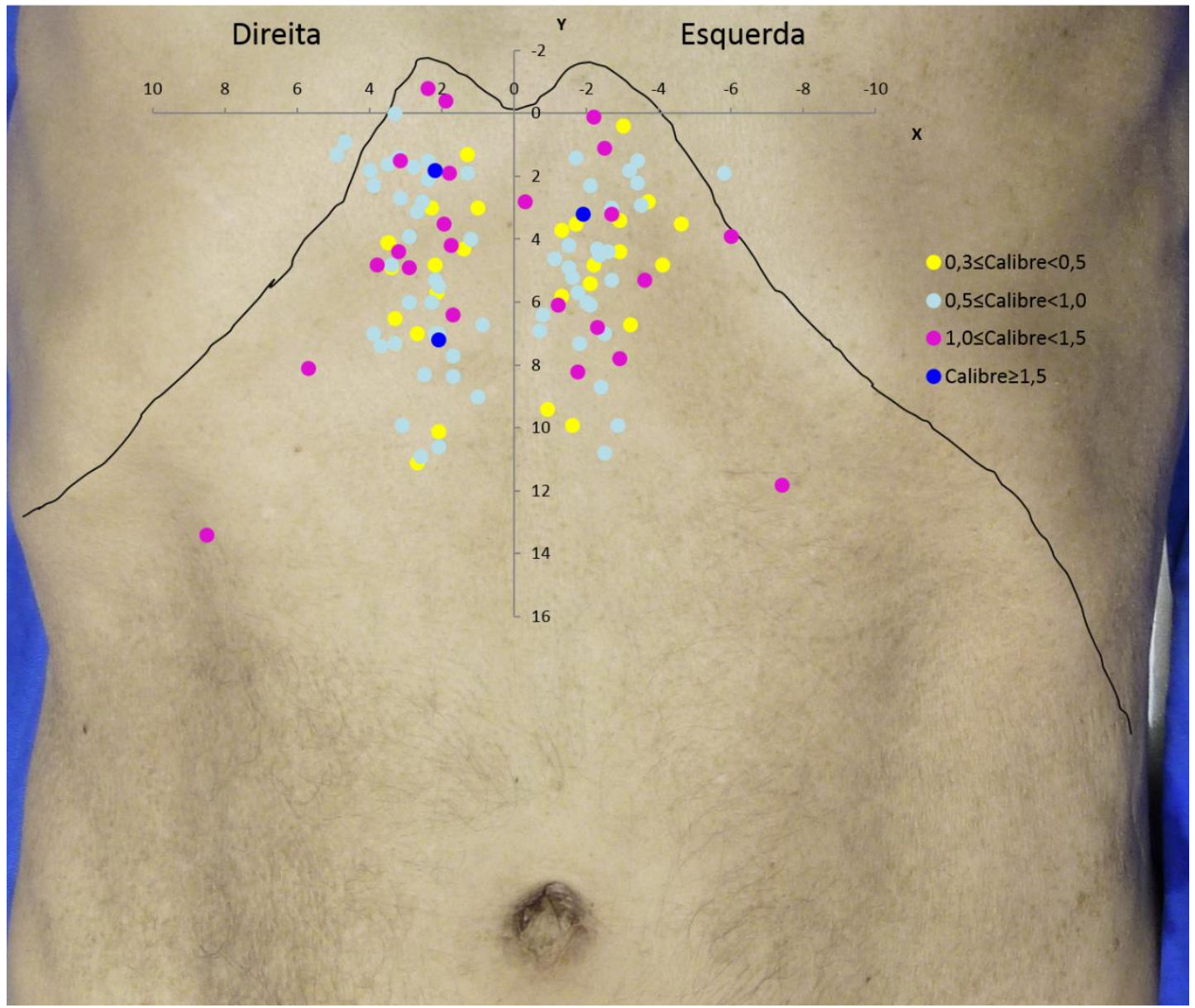

Figura 13: Dispersão das perfurantes epigástricas superiores supeficiais (SSEA) conforme o calibre. A linha negra representa a margem costal e o ponto $0 \times 0$, o ápice do apêndice xifoide. A distribuição das perfurantes foi medida a partir deste ponto, com eixo $\mathrm{x}$ orientado paralelo ao chão. A parte cranial está na base da figura, e a caudal, no ápice. Medidas de $X$ e $\mathrm{Y}$ em $\mathrm{cm}$, e calibre, em $\mathrm{mm}$.

Análise pareada entre lados direito e esquerdo pode ser feita para 49 pares de perfurantes e não houve diferença estatisticamente significativa para localização, coordenadas $x$ e y, e calibre em relação ao lado considerado $(p=0,357 ; 0,421$ e 0,252, respectivamente). Figura 14.

Em relação ao sexo, a análise pareada encontrou diferença significativa apenas na posição em relação ao eixo $x$ do lado esquerdo, que foi significativamente menor $(p=0,016)$ nas mulheres (masculino: $M=2,84, d p=1,42$; feminino: $M=1,92$, $\mathrm{dp}=0,88)$, conforme figura 15 . 


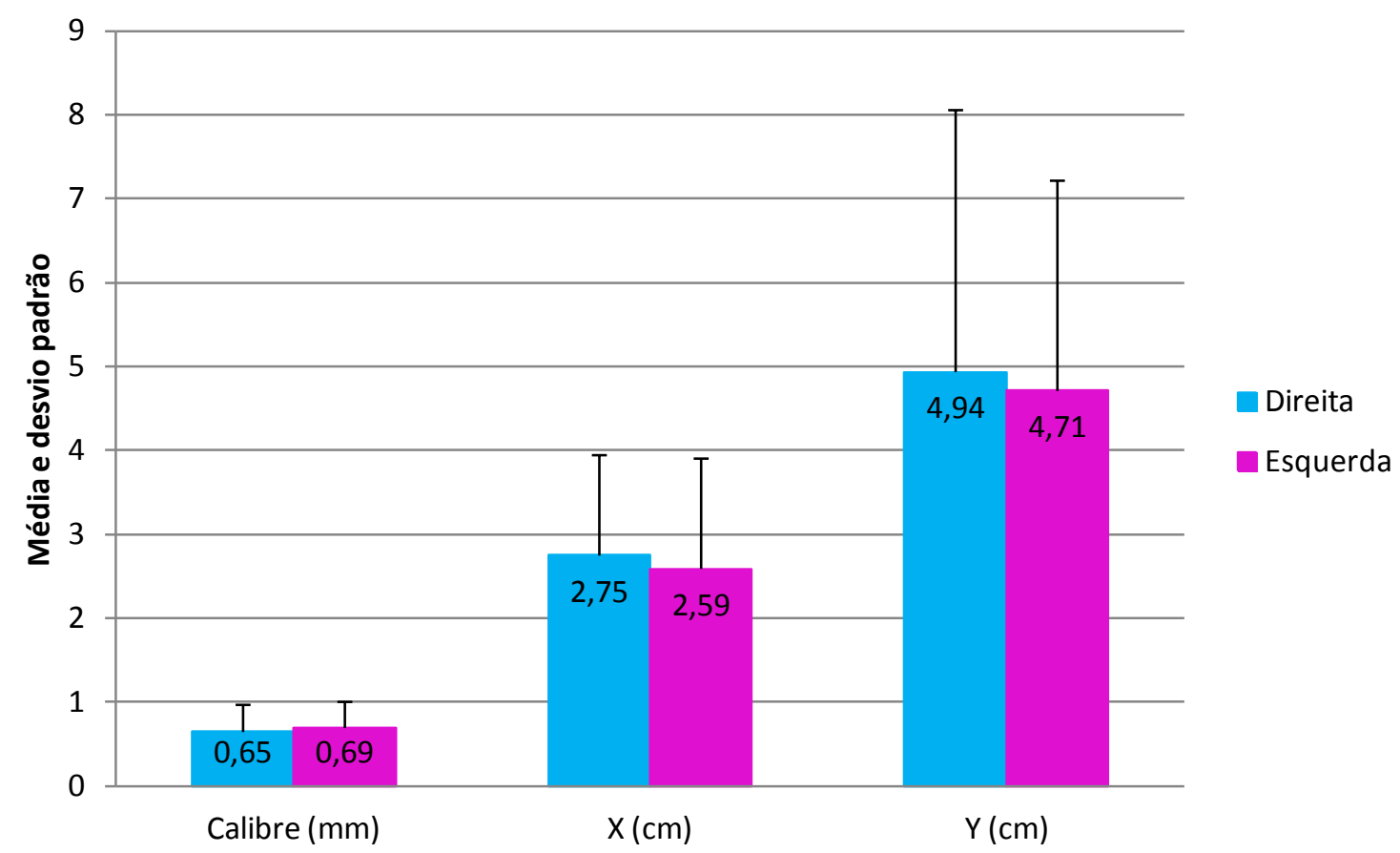

Figura 14: Análise pareada do calibre e localização das perfurantes SSEA em relação ao lado. Não houve diferença no calibre e localização das perfurantes em relação ao lado.

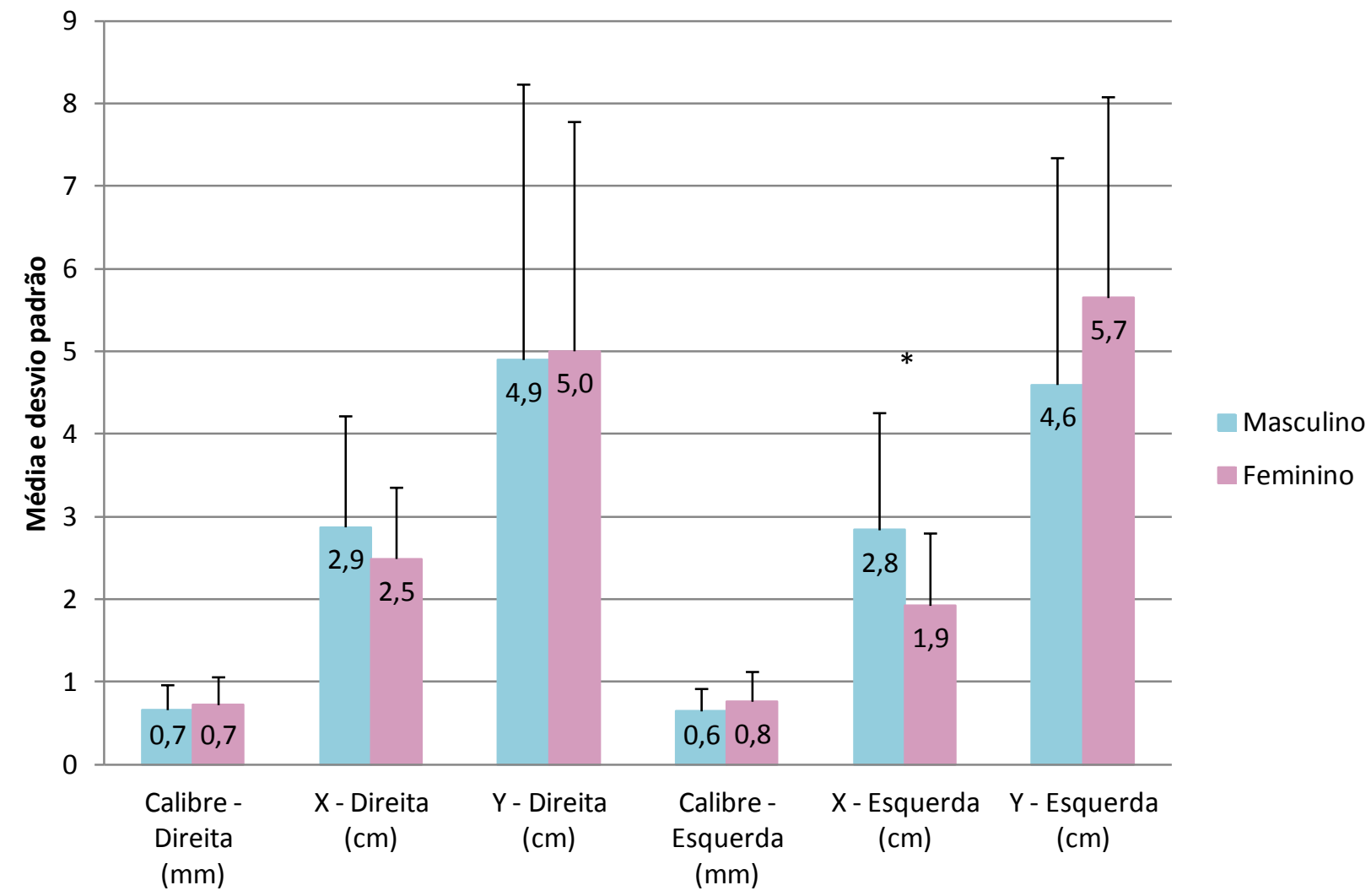

Figura 15: Análise pareada do calibre e localização das perfurantes SSEA segundo o sexo. *Localização das perfurantes no eixo $\mathrm{x}$ do lado esquerdo significativamente menor nas mulheres. Significante ao nível de $5 \%$. 
Pela análise de correlações de Pearson, não se observou correlação dos calibres com a localização das perfurantes nos eixos $X$ (direita: $r=0,06 ; p=0,64$; e esquerda: $r=0,13 ; p=0,37$ ) e $Y$ (direita: $r=0,007 ; p=0,97$; e esquerda: $r=0,02 ; p=$ $0,91)$ em ambos os lados. Também não houve correlação entre os calibres e localização das perfurantes SSEA com idade, peso e altura dos cadáveres. Houve correlação positiva dos calibres e das coordenadas correspondentes $\mathrm{x}$ e y para os lados direito e esquerdo (Tabela 3).

\begin{tabular}{|c|c|c|c|c|c|c|c|c|c|c|c|c|c|c|c|c|c|c|}
\hline \multirow{2}{*}{ Variável } & \multicolumn{3}{|c|}{ Calibre - Direita } & \multicolumn{3}{|c|}{ X-Direita } & \multicolumn{3}{|c|}{ Y-Direita } & \multicolumn{3}{|c|}{ Calibre - Esquerda } & \multicolumn{3}{|c|}{$X$-Esquerda } & \multicolumn{3}{|c|}{ Y-Esquerda } \\
\hline & $n$ & $\mathrm{r}$ & $\mathrm{P}$ & $\mathrm{n}$ & $\mathrm{r}$ & $P$ & $\mathrm{n}$ & $r$ & $P$ & $n$ & r & $P$ & $n$ & r & $P$ & $\mathrm{n}$ & r & $\mathrm{P}$ \\
\hline Idade & 62 & 0,027 & 0,835 & 62 & 0,031 & 0,808 & 62 & 0,199 & 0,121 & 52 & 0,162 & 0,251 & 52 & 0,133 & 0,348 & 52 & 0,141 & 0,318 \\
\hline Altura & 62 & $-0,022$ & 0,863 & 62 & 0,069 & 0,594 & 62 & $-0,024$ & 0,850 & 52 & $-0,214$ & 0,128 & 52 & 0,135 & 0,340 & 52 & $-0,185$ & 0,189 \\
\hline Peso & 62 & 0,107 & 0,408 & 62 & 0,093 & 0,474 & 62 & 0,154 & 0,231 & 52 & 0,040 & 0,781 & 52 & 0,196 & 0,163 & 52 & $-0,005$ & 0,969 \\
\hline Calibre - Direita & & & & 62 & 0,060 & 0,641 & 62 & $-0,007$ & 0,956 & 49 & 0,603 & $<0,001$ & 49 & 0,168 & 0,249 & 49 & $-0,076$ & 0,605 \\
\hline X-Direita & & & & & & & 62 & 0,143 & 0,267 & 49 & 0,140 & 0,337 & 49 & 0,548 & $<0,001$ & 49 & 0,163 & 0,263 \\
\hline Y - Direita & & & & & & & & & & 49 & $-0,072$ & 0,622 & 49 & $-0,072$ & 0,625 & 49 & 0,783 & $<0,001$ \\
\hline Calibre - Esquerda & & & & & & & & & & & & & 52 & 0,127 & 0,369 & 52 & $-0,016$ & 0,908 \\
\hline$X$ - Esquerda & & & & & & & & & & & & & & & & 52 & $-0,037$ & 0,794 \\
\hline
\end{tabular}

Tabela 3: Correlação pelo coeficiente de Pearson entre calibre das perfurantes SSEA, idade, altura e peso dos cadáveres. 


\subsubsection{Retalho osteomiocutâneo baseado nos vasos torácicos internos}

A dissecação anatômica do pedículo torácico interno foi feita em 31 cadáveres, 24 (77\%) do sexo masculino e 7 (23\%) do sexo feminino. Foi possível dissecar o retalho osteomiocutâneo baseado nos vasos torácicos internos em ambos os lados de todos os cadáveres, totalizando 62 retalhos. Sua composição final é o pedículo torácico interno, $6^{\circ}$ e $7^{\circ}$ arcos costais e músculo reto abdominal. $O$ ponto pivô para rotação para o segmento cefálico foi feito na margem inferior do primeiro arco costal.

Com os achados de distribuição vascular foi possível dividir o retalho em 3 tipos, de acordo com a irrigação para o sexto arco costal. No tipo I, os vasos intercostais para o sexto arco são ramos da artéria musculofrênica. No tipo II, a irrigação do sexto arco foi por ramo direto da torácica interna e, no tipo III, a irrigação foi dupla, tanto por ramo direto, como por ramo oriundo da musculofrênica (Figura 16 $A, B$ e $C$ respectivamente). 

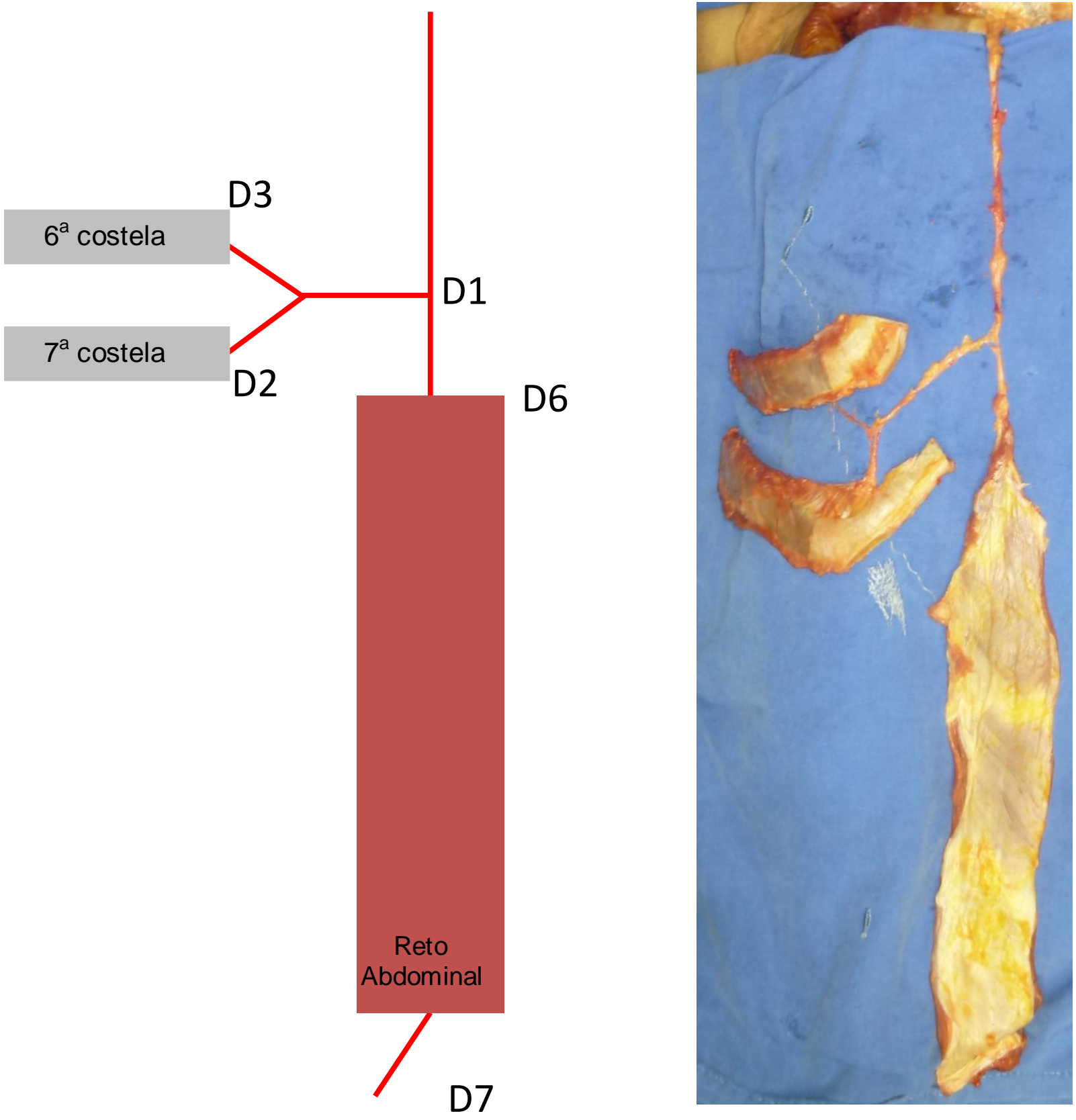

Figura 16A: Tipo I. Vaso intercostal para sexta costela é ramo da músculo-frênica. $D 1$ a $D 7$ conforme texto. 

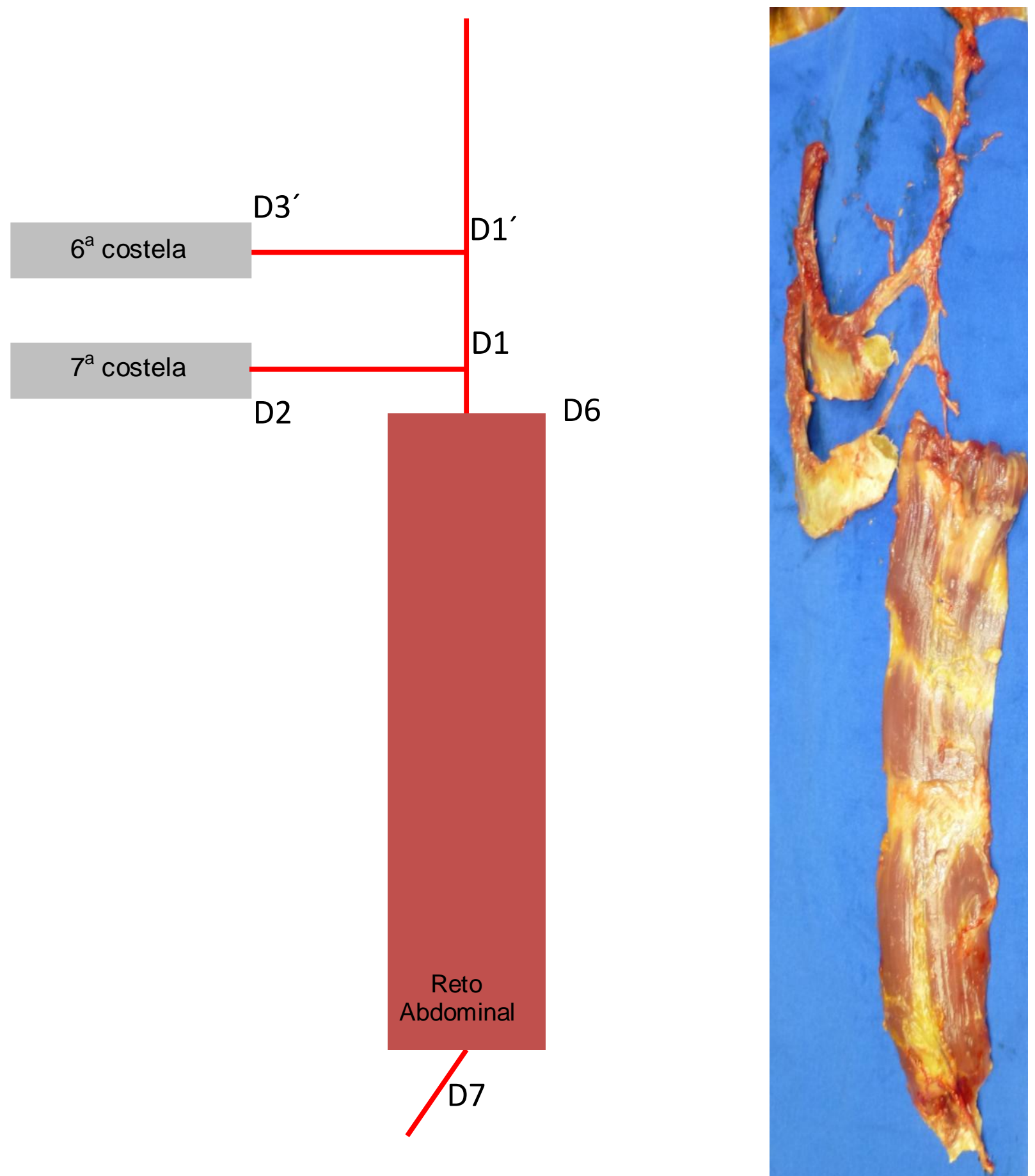

Figura 16B: Tipo II. Irrigação da sexta costela por ramo direto da torácica interna. D1 a D7 conforme texto. 

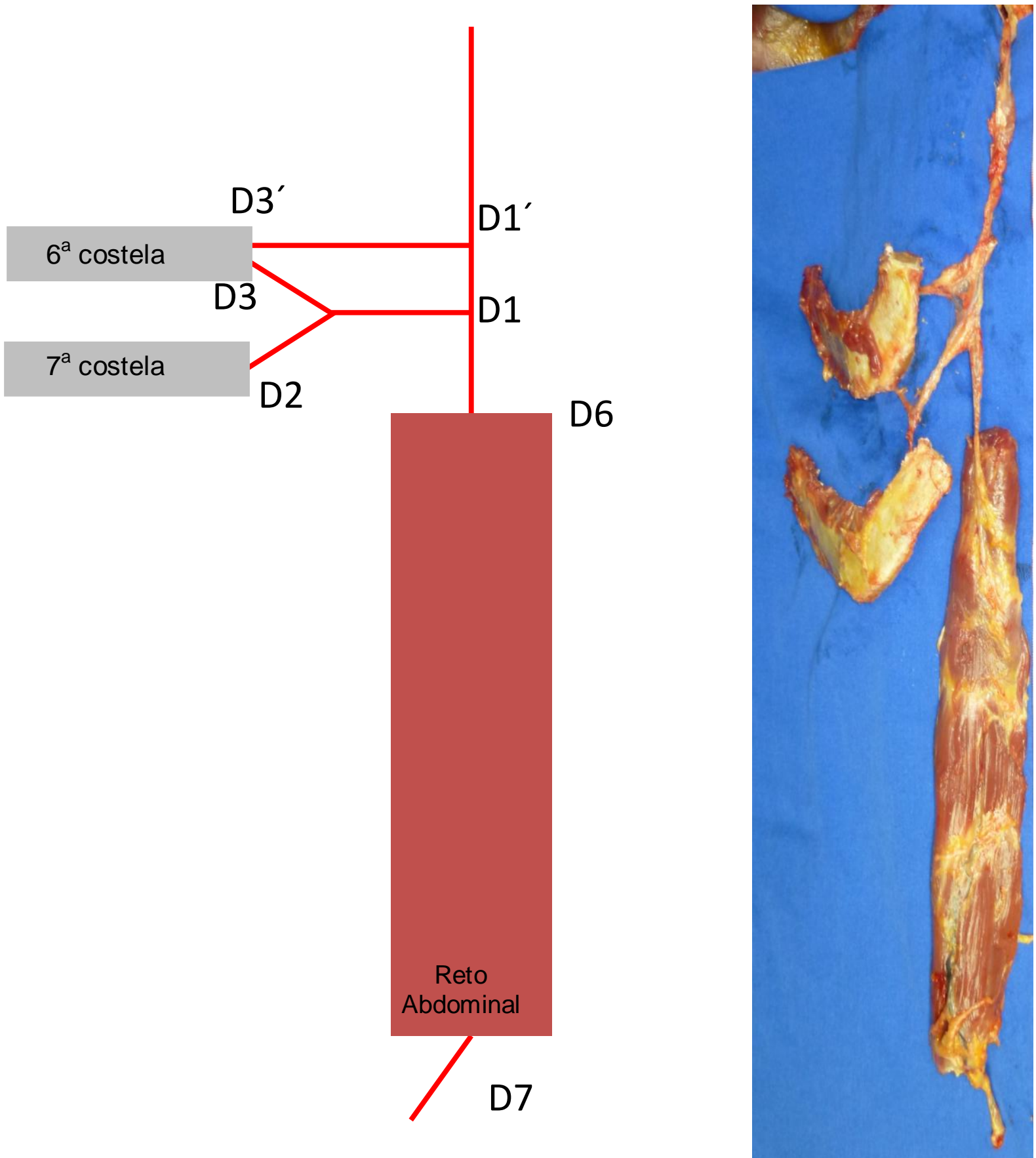

Figura 16C: Tipo III. Irrigação dupla da sexta costela, por ramo direto da torácica interna e por ramo da músculofrênica. D1 a D7 conforme texto. 
O tipo 1, em que a vascularização da sexta costela é uma única artéria oriunda da musculofrênica, foi o mais frequente, com 52 (83,8\%) ocorrências, sendo 26 em cada lado. O tipo II, com a vascularização do sexto arco proveniente de uma artéria intercostal que é ramo direto da torácica interna, teve duas ocorrências do lado esquerdo e três do lado direito (8,1\%). Já o tipo III, onde há uma vascularização dupla do sexto arco costal, também correspondeu a $8,1 \%$ dos achados de dissecação, mas com duas ocorrências à direita e três à esquerda.

Foram medidas as distâncias dos pedículos e o calibre da artéria em cada uma das localizações. Os comprimentos dos pedículos foram divididos de acordo com reparos anatômicos conforme se segue:

- D1: comprimento da artéria torácica interna desde a margem inferior do primeiro arco costal até a saída da artéria musculofrênica;

- D1': comprimento da torácica interna desde a margem inferior do primeiro arco costal até a saída do ramo intercostal direto para a sexta costela (presente nos tipos II e III apenas);

- D2: comprimento do pedículo para a sétima costela a partir da torácica interna;

- D3: comprimento do pedículo para a sexta costela a partir da torácica interna (D2 e D3 incluem o comprimento da artéria musculofrênica e representam a somatória desta com o ramo intercostal para cada costela);

- D3': comprimento do ramo direto para a sexta costela a partir da torácica interna (presente nos tipos II e III apenas);

- D4: comprimento do pedículo ósseo da sétima costela (somatória de D1 e D2);

- D5: comprimento do pedículo ósseo da sexta costela (somatória de D1 e D3);

- D5': comprimento do pedículo ósseo secundário da sexta costela (somatória de D1' e D3');

- D6: comprimento do pedículo vascular até o início do músculo reto abdominal (somatória do comprimento da torácica interna e da DSEA);

- D7: comprimento total do pedículo desde a margem inferior da primeira costela até o final da DIEA. 
As medidas dos comprimentos das distâncias D1 a D7 descritas acima estão relacionadas na Tabela 4 e ilustradas nas figuras 17 e 18. Não houve diferença estatisticamente significativa entre os comprimentos dos pedículos ósseos da sexta (D5 e D5') e da sétima costela (D4), entre si e em relação ao lado (Fig. 19).

\begin{tabular}{|l|c|c|c|c|c|}
\hline Comprimento do pedículo & N & Mínimo & Máximo & Média & $\begin{array}{c}\text { Desvio } \\
\text { padrão }\end{array}$ \\
\hline D1 - Direita & 29 & 9 & 17,5 & 14,5 & 1,9 \\
\hline D1 - Esquerda & 30 & 11 & 17,5 & 14,9 & 1,9 \\
\hline D1' - Direita & 5 & 13 & 14 & 13,6 & 0,4 \\
\hline D1' - Esquerda & 5 & 10 & 16,5 & 14,0 & 2,4 \\
\hline D2 - Direita & 27 & 2,3 & 13 & 7,6 & 2,5 \\
\hline D2 - Esquerda & 27 & 2,4 & 11 & 6,5 & 2,3 \\
\hline D3 - Direita & 16 & 2,8 & 9,9 & 7,2 & 1,8 \\
\hline D3 - Esquerda & 18 & 4,2 & 11,5 & 6,9 & 2,0 \\
\hline D3' - Direita & 5 & 3,6 & 5,8 & 4,7 & 1,0 \\
\hline D3' - Esquerda & 5 & 2 & 6,2 & 3,8 & 1,6 \\
\hline MF - Direita & 28 & 1,2 & 9,5 & 5,3 & 1,7 \\
\hline MF - Esquerda & 28 & 2,2 & 11 & 4,8 & 2,0 \\
\hline D4 - Direita & 29 & 14 & 30 & 21,6 & 3,5 \\
\hline D4 - Esquerda & 30 & 12 & 26,5 & 20,8 & 3,7 \\
\hline D5 - Direita & 29 & 13 & 25,5 & 18,5 & 4,0 \\
\hline D5 - Esquerda & 30 & 12 & 26 & 19,1 & 4,4 \\
\hline D5' - Direita & 5 & 16,6 & 19,5 & 18,3 & 1,3 \\
\hline D5' - Esquerda & 29 & 13,3 & 22,7 & 17,8 & 3,4 \\
\hline D6 - Direita & 16 & 25 & 19,9 & 2,3 \\
\hline D6 - Esquerda & 15,5 & 23,4 & 19,7 & 2,1 \\
\hline D7 - Direita & 43 & 56 & 50,1 & 3,6 \\
\hline D7 - Esquerda & 29 & 56 & 49,4 & 3,4 \\
\hline
\end{tabular}

Tabela 4: Comprimentos dos pedículos avaliados. N: número de medidas feitas para aquela distância. Média: comprimento médio das distâncias em cm. D1 a D7, no texto. 


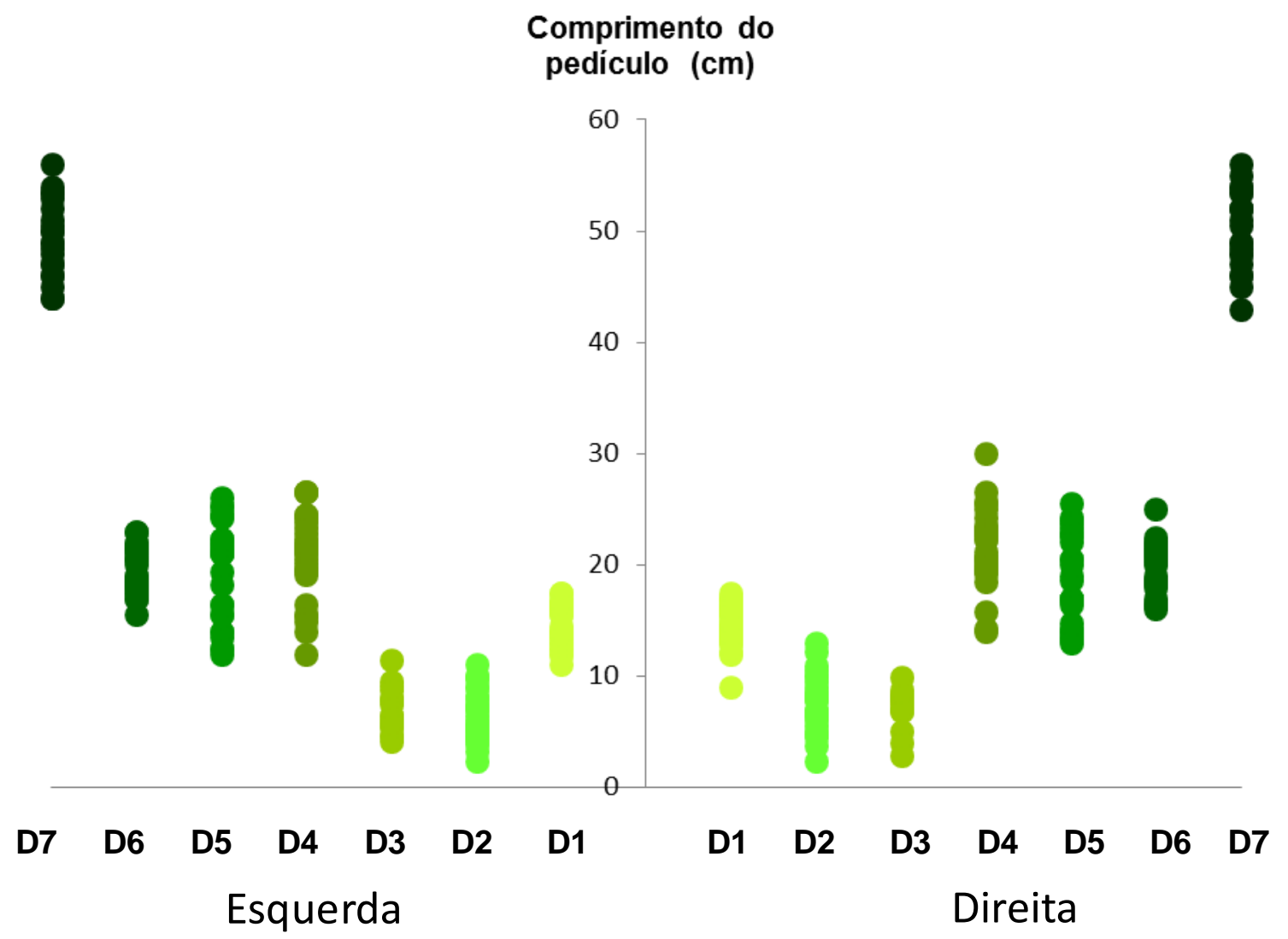

Figura 17: Distribuição das medidas dos comprimentos dos pedículos vasculares de acordo com o lado. D1 a D7 conforme o texto. 


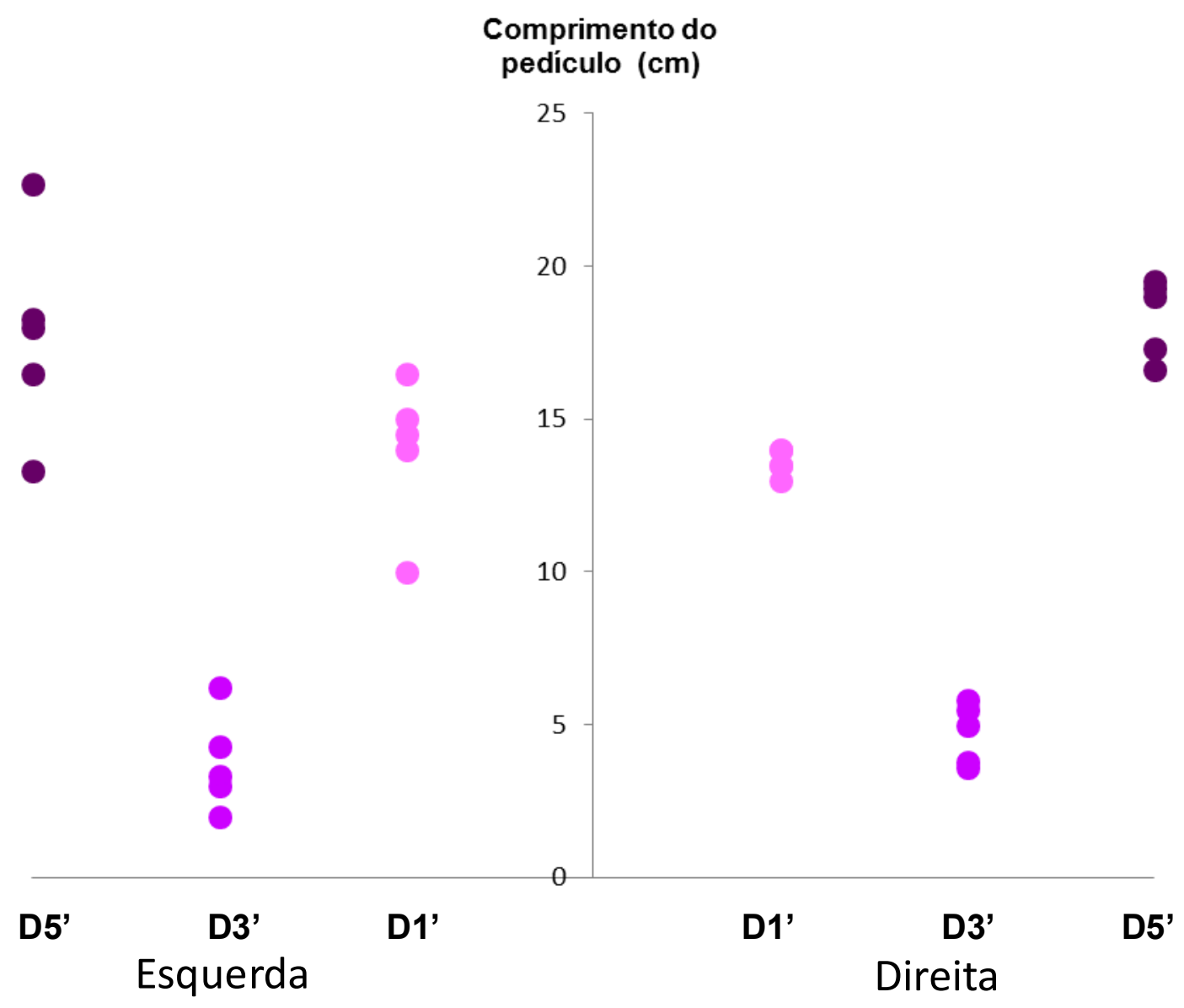

Figura 18: Distribuição das medidas dos pedículos acessórios para a sexta costela de acordo com o lado. D1', D3' e D5' conforme o texto. 


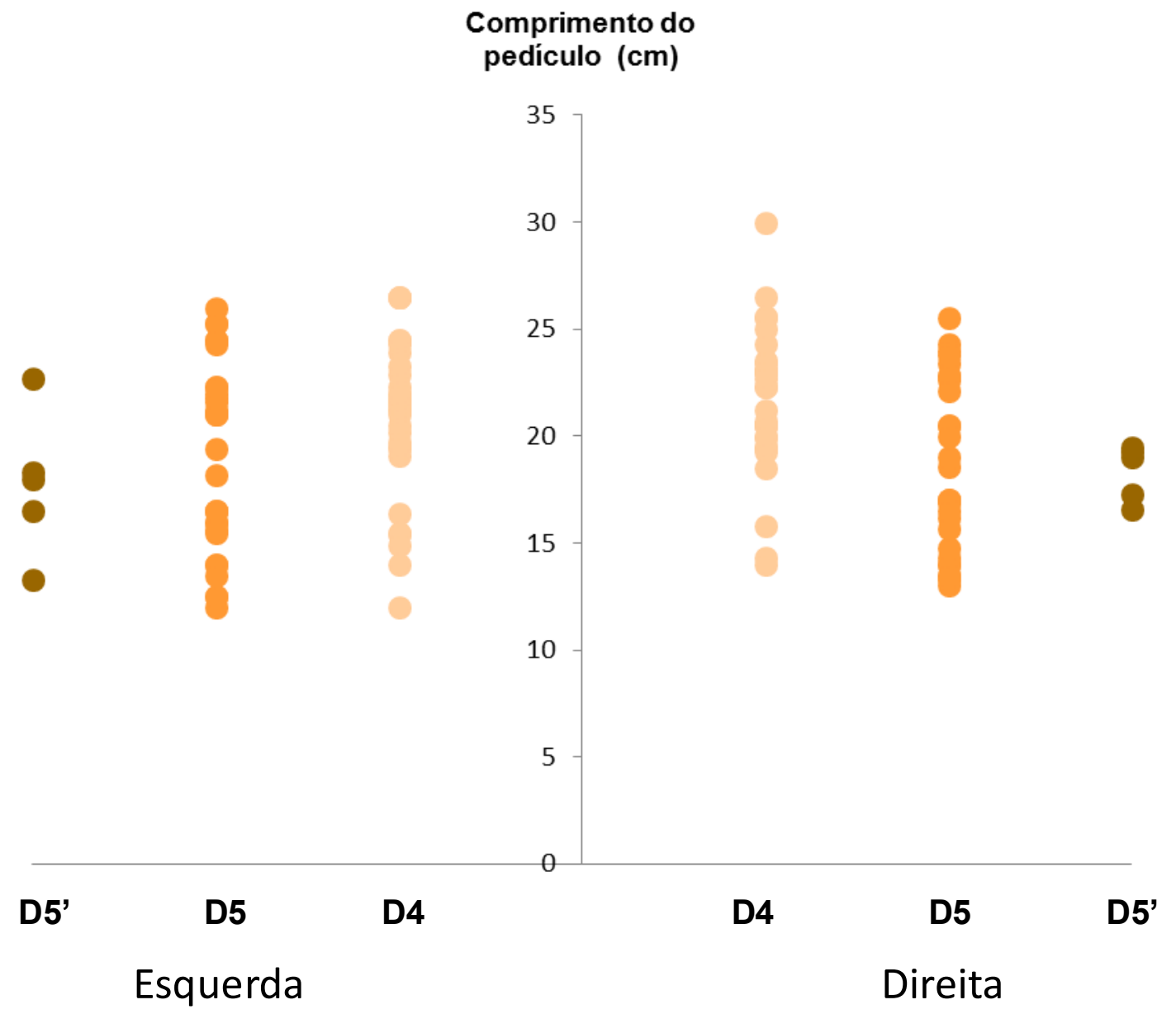

Figura 19: Comparação, em relação ao lado, dos comprimentos dos pedículos para o componentes ósseos dos retalhos. D4: pedículo ósseo para sétima costela, D5: pedículo ósseo para a sexta costela e D5': pedículo ósseo acessório para sexta costela, presente nos tipos II e III. 
A análise pareada das medidas D1 a D7 encontrou diferença estatisticamente significativa, pelo teste de t de Student, apenas nos comprimentos do pedículo para a sexta costela a partir da torácica interna, $D 2$, que foi maior $(p=0,025)$ no lado direito em relação ao esquerdo (direito: $M=7,6 \mathrm{~cm}, d p=2,6$; esquerdo: $M=6,5 \mathrm{~cm}$, $\mathrm{dp}=2,2$ ); e no comprimento total do pedículo até o final da DIEA, D7, também maior $(p=0,03)$ à direita (direito: $M=50,2 \mathrm{~cm}, d p=3,7$; esquerdo: $M=49,6 \mathrm{~cm}, d p=3,4)$. Figura 20.

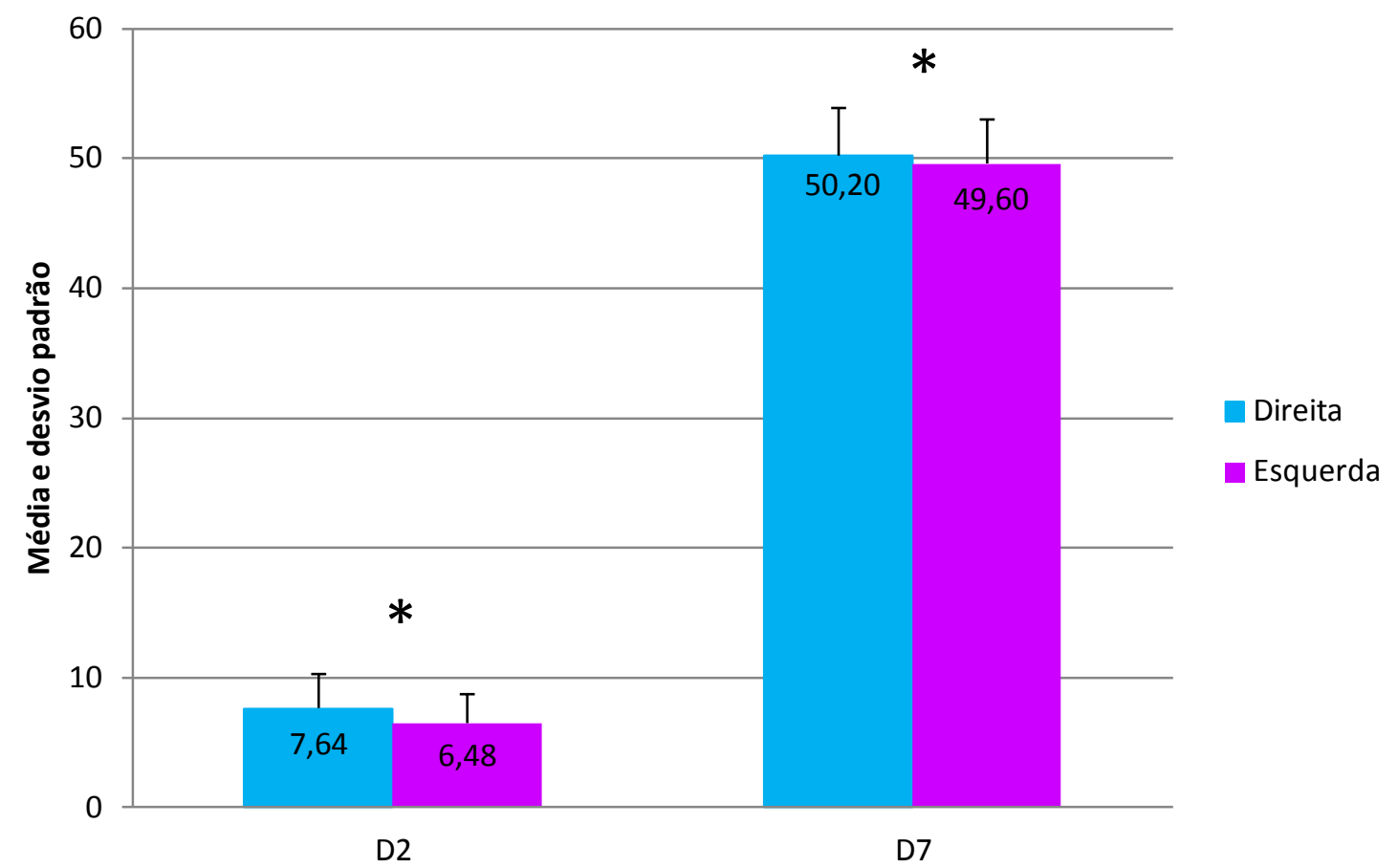

Figura 20: Análise pareada das medidas D2 e D7 em relação ao lado. Houve diferença estatisticamente significativa, pelo teste de t de Student, nos comprimentos do pedículo para a sexta costela a partir da torácica interna, D2; e no comprimento total do pedículo até o final da DIEA, D7. Demais medidas, D1, D1', D3, D3', D4, D5, D5' e D6 não apresentaram diferença significativa *Significante ao nível de 5\%. 
Em relação ao sexo, a análise não-pareada encontrou diferença significativa nos comprimentos de D1, D4 e D6 pelo teste de Mann-Whittney. Essas medidas foram significativamente maiores nos homens do que nas mulheres. No caso de D1, isso foi verdade apenas para o lado esquerdo $(p=0,03$; masculino: $M=15,5 \mathrm{~cm}$, $d p=1,6$; feminino: $M=13,2 \mathrm{~cm}, d p=1,5)$. As medidas de $D 4$ foram maiores nos homens tanto à direita $(p=0,017$; masculino: $M=22,5 \mathrm{~cm}, d p=3,2$; feminino: $M=19,0$, $d p=3,3)$, quanto à esquerda $(p=0,002$; masculino: $M=21,9 \mathrm{~cm}, d p=2,9$; feminino: $M=17,2, \quad d p=4,1)$. Já o comprimento $D 6$, apenas 0 lado esquerdo foi significativamente maior no sexo masculino $(p=0,010$; masculino: $M=20,2 \mathrm{~cm}$, $d p=2,0$; feminino: $M=18,0 \mathrm{~cm}, d p=1,2)$. Figura 21 .

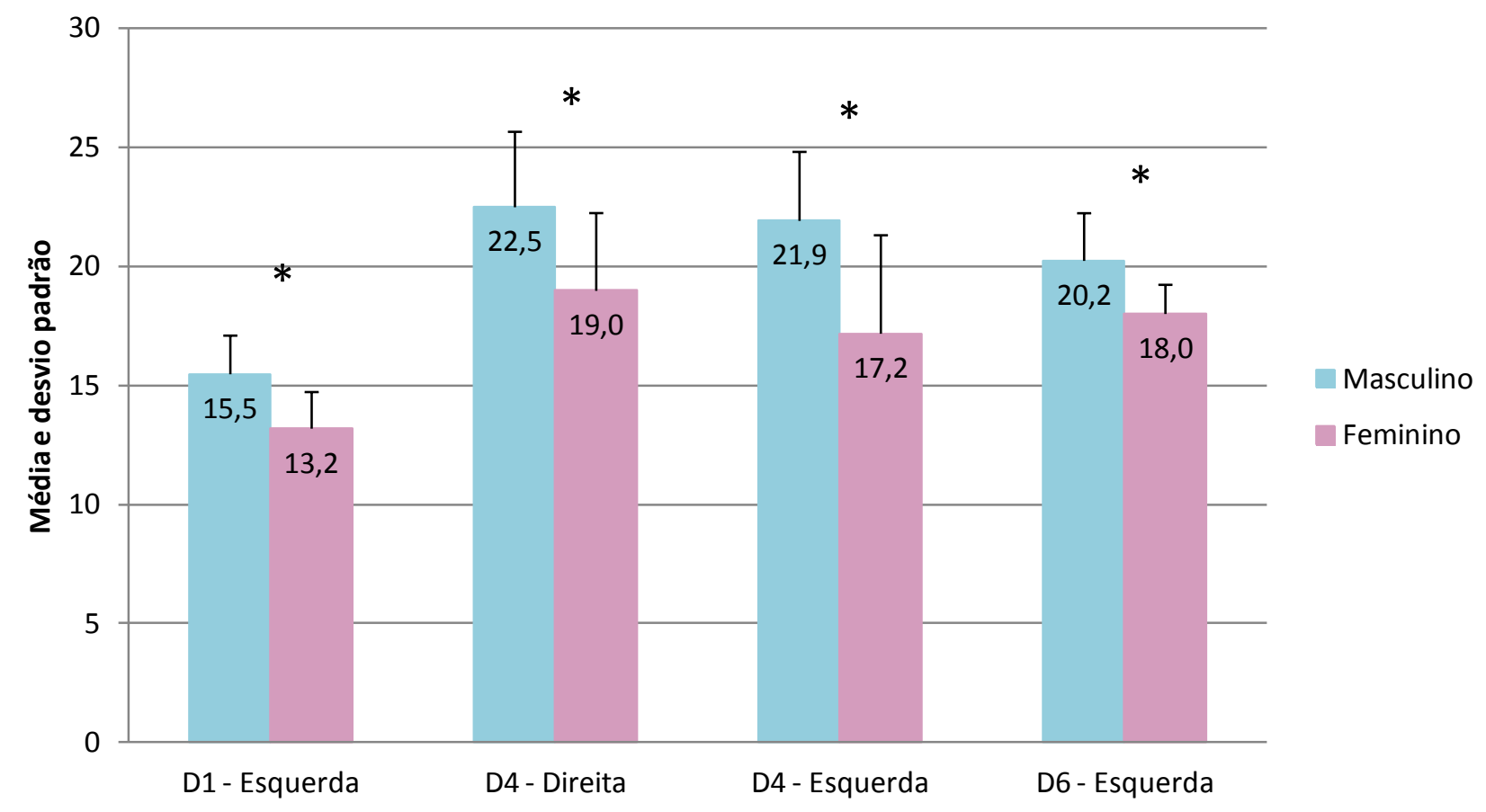

Figura 21: Análise não pareada dos comprimentos D1 a D7 em relação ao sexo e ao lado. Pelo teste de Mann-Whittney houve diferença significativa para as medidas D1 à esquerda, D4 bilateralmente e D6 à esquerda, sendo maiores nos homens, conforme figura. *Significante ao nível de 5\%. 
Pela análise de correlações de Pearson, não se observou correlação dos comprimentos dos pedículos de D1 a D7, de ambos os lados, com as variáveis de peso, altura e idade dos cadáveres; exceto pelo comprimento de D7 do lado esquerdo, que mostrou correlação positiva com o peso dos cadáveres $(r=0,44$; $p=0,044)$.

Quanto aos calibres dos pedículos, eles foram medidos nos diversos pontos e discriminados conforme a topografia. Foram realizadas medidas em ambos os lados, direito e esquerdo, nos vasos torácicos internos ao nível da saída da intercostal para $6^{a}$ costela, nos vasos musculofrênicos, nos vasos intercostais para $6^{\underline{a}}$ e $7^{\underline{a}}$ costelas, e nos vasos DSEA. Todos os pedículos medidos apresentavam uma artéria e duas veias. Pelo esvaziamento vascular dos cadáveres, houve dificuldades técnicas para adequada mensuração dos calibres venosos após isolamento dos pedículos e os dados obtidos foram descartados.

O menor calibre da artéria torácica interna ao nível da intercostal para a sexta costela foi de $1,0 \mathrm{~mm}$, e o maior foi de $2,6 \mathrm{~mm}$, atingindo uma média de 1,8 $\mathrm{mm}$ à direita e $1,7 \mathrm{~mm}$ à esquerda. Os calibres das artérias musculofrênicas variaram de 0,5 a $1,2 \mathrm{~mm}$ e das intercostais para $6^{\underline{a}}$ e $7^{\underline{a}}$ costelas, de 0,4 a $1,5 \mathrm{~mm}$. As DSEA apresentaram um calibre médio de 1,3 mm à direita, e 1,2 mm à esquerda A tabela 3 ilustra os resultados obtidos. Após análise estatística, não encontrou-se diferença significativa na análise pareada dos calibres arteriais em cada parte do pedículo com os lados direito e esquerdo (Fig. 22). Também não houve diferenças com relação ao sexo (Fig 23 A e B). 
Calibres arteriais nos pedículos

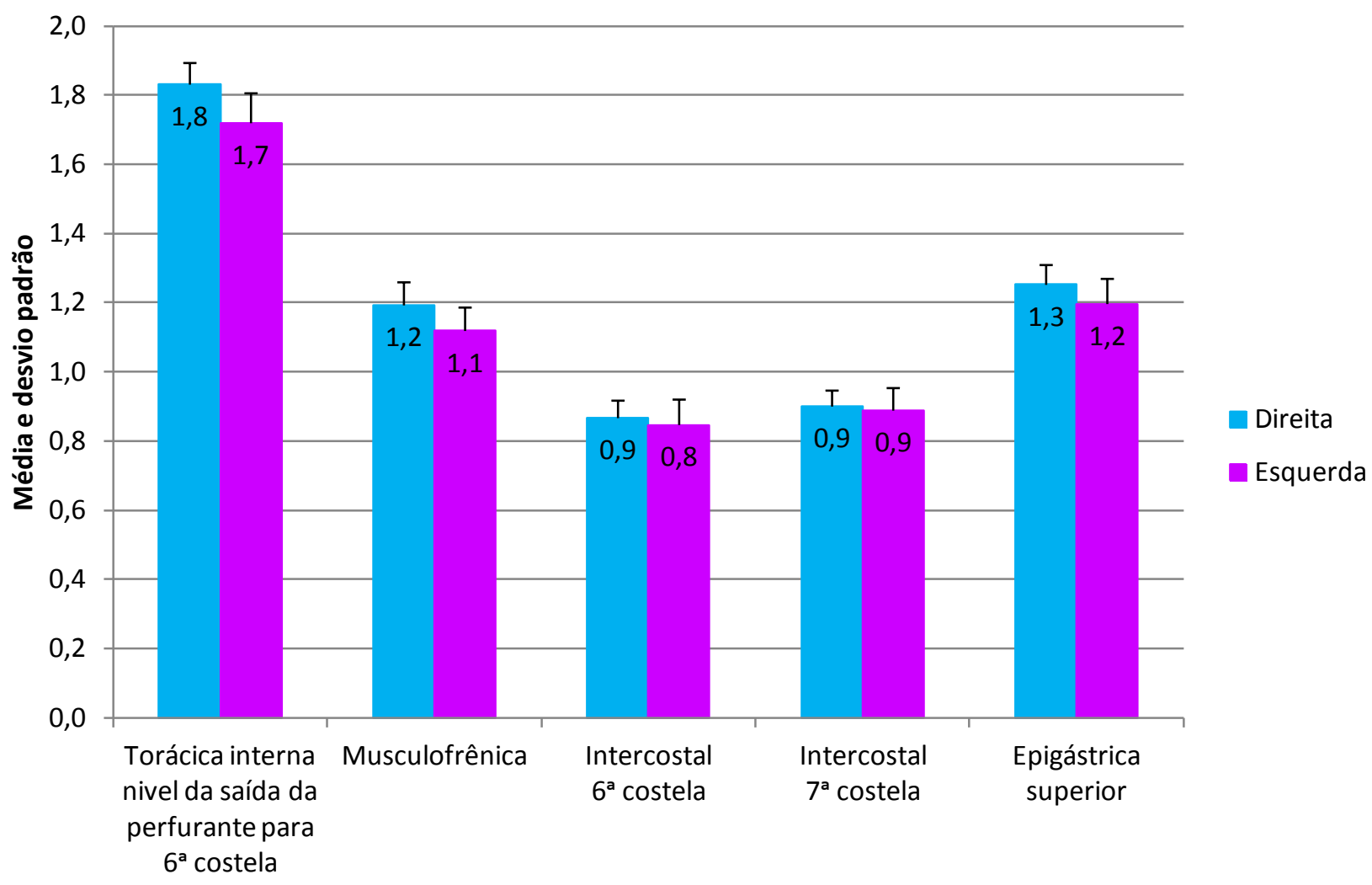

Figura 22: Análise pareada dos calibres arteriais em cada parte do pedículo em relação ao lado. Não houve diferença estatisticamente significativa. 
Calibres arteriais à esquerda

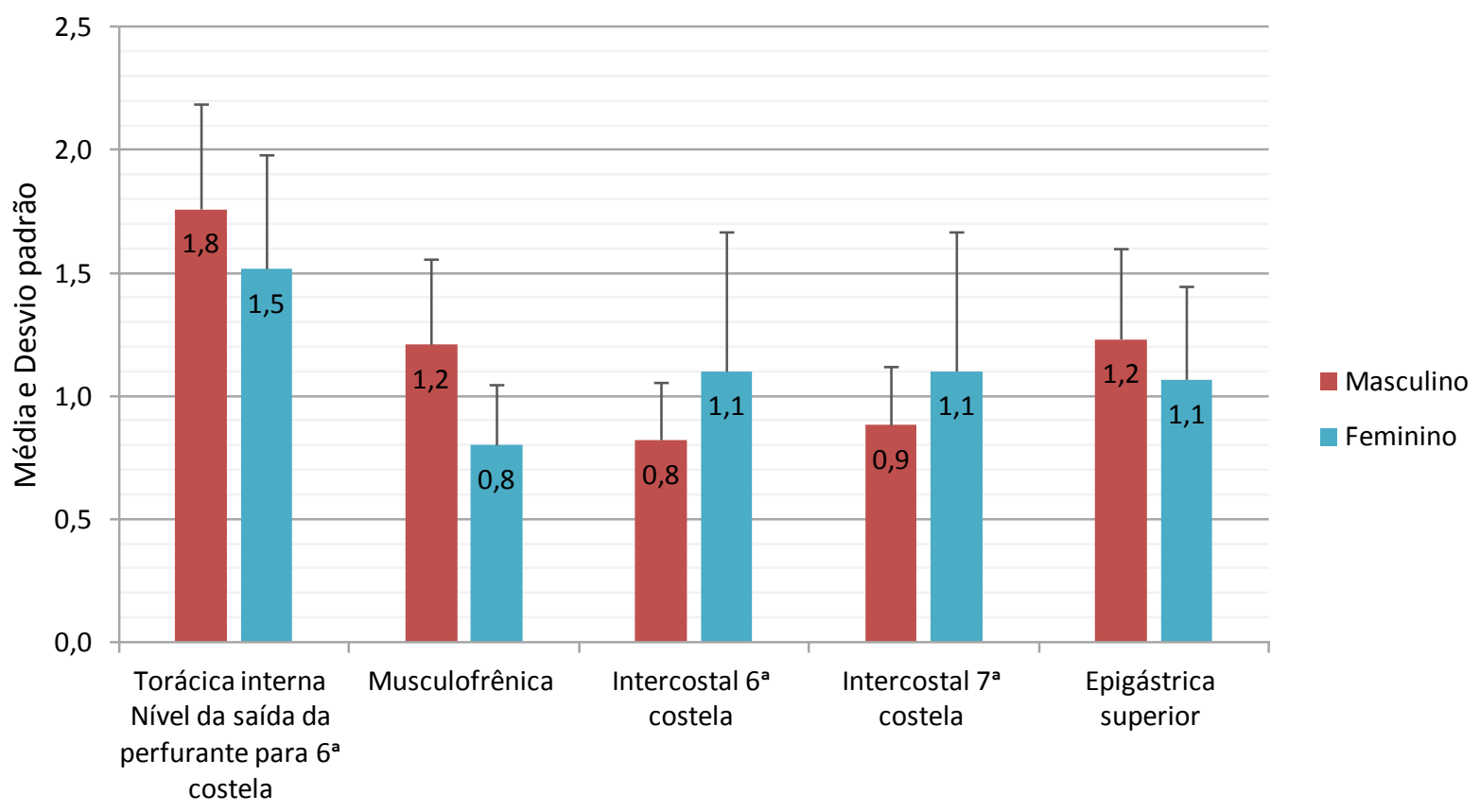

Figura 23 A: Análise pareada dos calibres arteriais em cada parte do pedículo à esquerda com relação ao sexo. Não houve diferença estatisticamente significativa.

Calibres arteriais à direita

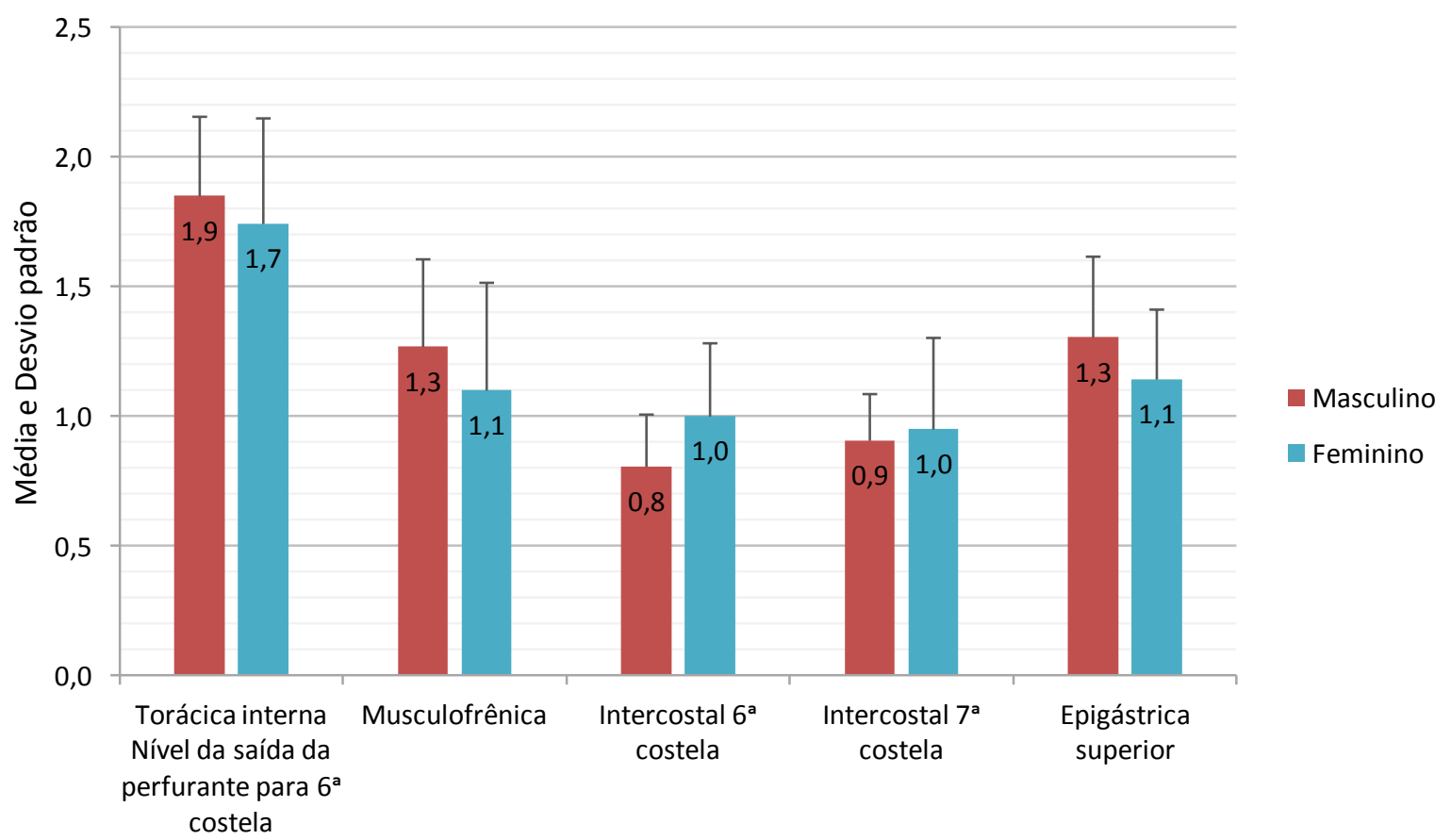

Figura 23 B: Análise pareada dos calibres arteriais em cada parte do pedículo à direita com relação ao sexo. Não houve diferença estatisticamente significativa. 
Pela análise de correlações de Pearson, não foi encontrada correlação entre os calibres dos vasos em cada parte do pedículo com idade, peso e altura; exceto por uma correlação positiva entre o calibre da artéria torácica interna ao nível da saída da perfurante para 6 ${ }^{\text {a }}$ costela, ou seja, em D1, à direita e o peso dos cadáveres $(r=0,409 ; p=0,028)$. Figura 24.

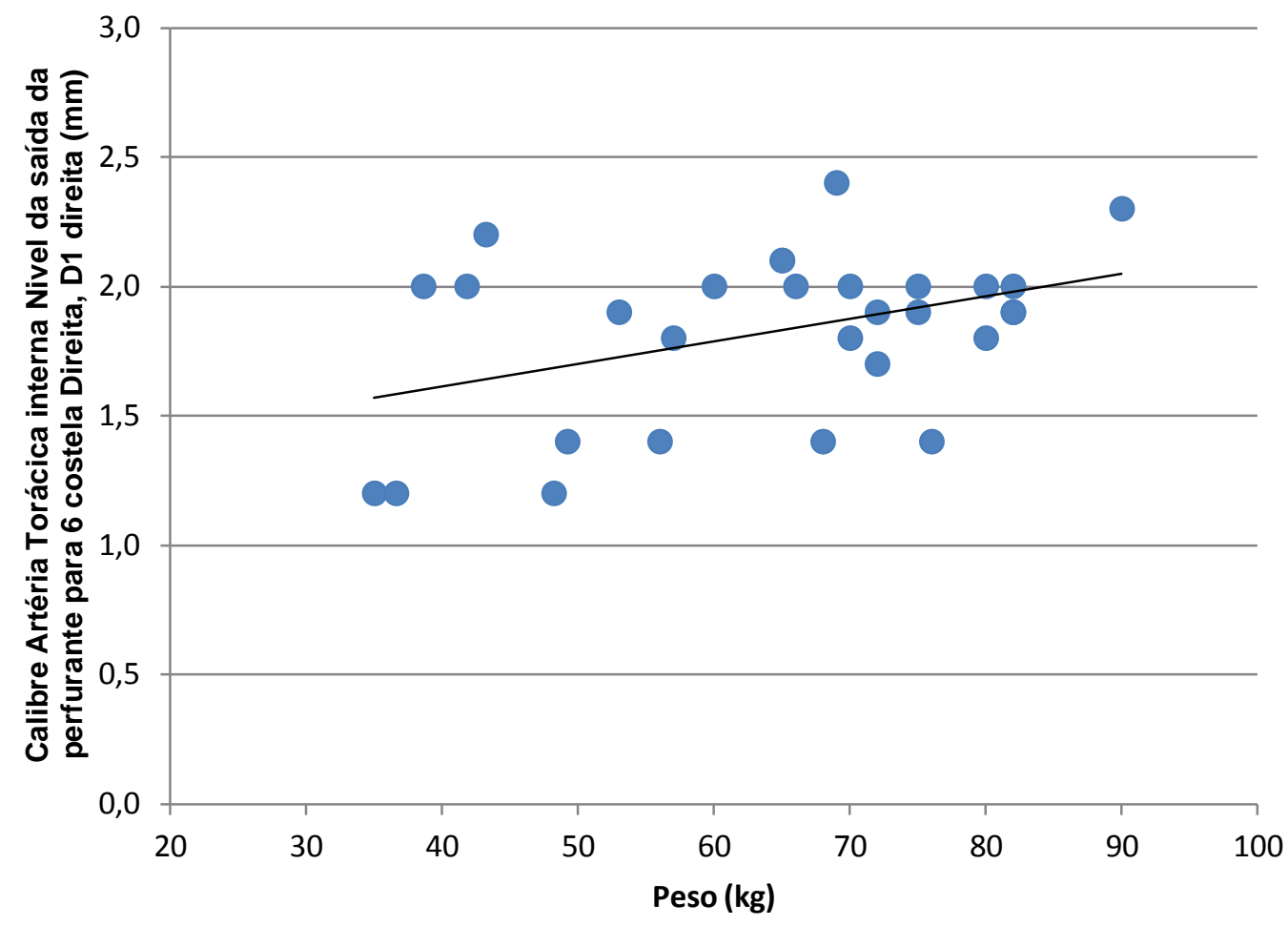

Figura 24: Correlação positiva do calibre da artéria torácica interna ao nível da saída da $6^{\underline{a}}$ costela à direita ( $D 1$ direita) e o peso dos cadáveres $(r=0,409 ; p=0,028)$. 
5. Discussão 
As reconstruções em cabeça e pescoço sempre foram um desafio para o cirurgião plástico. O desenvolvimento de retalhos locorregionais nas décadas de 60 e 70 resolveram parcialmente as dificuldades, como o retalho deltopeitoral descrito por Bakamjian em $1965^{62}$ e o primeiro relato de uso do retalho miocutâneo de músculo peitoral maior para reconstrução de cabeça e pescoço por Ariyan, em 1979. ${ }^{63,64}$ Simultaneamente, desenvolvia-se a técnica de transferência microcirúrgica de retalhos, cutâneos, musculares e ósseos ${ }^{3,65,66}$. Nesta época, muitos cirurgiões plásticos buscavam alternativas para as complexas reconstruções que envolviam defeitos ósseos no segmento cefálico, principalmente mandíbula. Até então as opções de reconstruções com osso vascularizado restringiam-se a porções ósseas aderidas às pontas de retalhos miocutâneos ou cutâneos, com irrigação periostal limítrofe e dimensões restritas, sem que houvesse uma vascularização óssea direta, o que impedia osteotomias e moldagem adequada. Foram utilizados músculo peitoral maior com costela, ${ }^{67}$ músculo serrátil anterior com costela, ${ }^{68}$ esternocleidomastóide com clavícula, ${ }^{69}$ e trapézio com parte da escápula. ${ }^{70}$

Nesta época já estudava-se a vascularização costal e o sistema torácico interno, o próprio Ariyan et al descreveu, em 1978, a confiabilidade da vascularização costal por via anterior, ou seja, pelos vasos torácicos internos. ${ }^{50} \mathrm{Em}$ 1982, Hendel et al descreveu, através de estudo em cães, que a vascularização costal é idêntica tanto por via anterior, pela irrigação periostal das artérias intercostais anteriores; quanto por via posterior, pelos vasos nutridores ósseos das intercostais posteriores; confrontando o conceito de predominância pela via posterior que existia até então. ${ }^{71} \mathrm{O}$ primeiro trabalho que demonstrou a possibilidade de transferência de um retalho osteomiocutâneo de costela baseado nos vasos torácicos internos havia sido publicado por Strauch et al em 1971, que relatou sua experiência com cirurgias em 17 cachorros. Apesar dos retalhos transferidos permanecerem viáveis, ele obteve mortalidade dos animais maior que $60 \%$ e deiscência esternal em todos os cães. Neste mesmo trabalho, o autor mostrou a possibilidade de transferência do pedículo torácico interno em uma dissecação de cadáver. ${ }^{48}$ Posteriormente, Ketchum et al, em 1974, publicou a transferência da sétima costela pediculada nos vasos torácicos internos para reconstrução mandibular em uma paciente vítima de ferimento por arma de fogo. ${ }^{49} \mathrm{~A}$ dissecação do pedículo foi feita através de esternotomia longitudinal e fratura de todas as sincondroses de $1^{\underline{a}}$ a $6^{\underline{a}}$ costelas. ${ }^{49}$ Talvez pelo alto índice de complicações, pelas 
dificuldades técnicas da dissecação intratorácica dos vasos torácicos internos e pela ausência de treinamento pelos cirurgiões plásticos para cirurgias intratorácicas, esta técnica, que já era considerada de exceção para casos muito selecionados, foi esquecida. A via anterior ainda foi utilizada para transferência livre de costela na reconstrução primária de defeito mandibular após a ressecção de um adamantinoma. Neste caso, publicado em 1982, Song et al levou a quarta costela direita com pedículo baseado na intercostal anterior. ${ }^{72}$ Em 1988, Cook et al descreveu 2 casos de reconstrução mandibular com quinta costela pediculada nos vasos torácicos internos, dissecados através de esternotomia. O autor levou apenas a parte óssea e teve que fazer retalhos miocutâneos de peitoral maior para reconstrução de partes moles. ${ }^{51}$

Dentre as opções microcirúrgicas para osso vascularizado, além da costela, ${ }^{73}$ foram descritos diversos retalhos: crista ilíaca, ${ }^{74,75}$ rádio, ${ }^{76}$ segundo metatarso ${ }^{77}$ e fíbula $^{78,79}$. Em 1989, quando Hidalgo descreveu o uso do retalho fibular para reconstrução mandibular, ${ }^{78}$ obteve-se um osso bem vascularizado e com boa massa óssea, capaz de suportar osteotomia e o stress mecânico a que será submetido ao substituir a mandíbula. Desde então, o retalho fibular e seus aperfeiçoamentos, com ilha cutânea ${ }^{80}$ e componente muscular, tem sido a escolha para reconstruções em cabeça e pescoço, sobretudo de mandíbula. No entanto, apesar de todos estes avanços, ainda existem casos extremos em que o paciente encontra-se sem vasos receptores no pescoço, geralmente por múltiplas recidivas e ressecções; radioterapia; reconstruções prévias, microcirúrgicas ou não; fístulas; infecções e esvaziamentos cervicais. Nestes casos, o cirurgião plástico deve ter alternativas não usuais no seu arsenal.

O retalho de costela pediculado nos vasos torácicos internos foi esquecido e ocultado pelo grande avanço da microcirurgia e os receios em relação à dissecação e área doadora. A costela é um osso fino, que sempre foi utilizado como enxerto, pela disponibilidade abundante, com resultados imprevisíveis e dependentes das condições locais. Nos pacientes oncológicos, estas condições geralmente são desfavoráveis. Portanto, com o surgimento de novas opções de retalhos ósseos vascularizados, a costela foi praticamente abandonada. Desde a década de 80 houve apenas um relato na literatura, por Arons e Guyuron em 1995, do uso de costela pediculada nos vasos torácicos internos. Os autores levaram a sexta costela com componente miocutâneo de reto abdominal, ambos pediculados na torácica 
interna, para reconstrução mandibular e de terço inferior da face em uma paciente de 25 anos com calcinose universal, previamente submetida a 29 cirurgias, inclusive duas fíbulas livres. A reconstrução foi feita em 2 tempos por congestão do retalho, que foi deixado 8 dias na região clavicular para acomodação. ${ }^{52}$

\subsection{Estudo anatômico}

\subsubsection{Vasos epigástricos superiores superficiais (SSEA)}

Esta perfurante irriga a pele do abdome superior com uma orientação transversal, a partir da linha média, para cada lado. Ela permite levar uma ilha de pele separada com rotação e posicionamento individual

Os dados encontrados demonstraram que a localização e o calibre das SSEA independem do sexo, altura e peso dos cadáveres. Também não há relação entre calibre das perfurantes e lado direito ou esquerdo. A única diferença estatística foi que a distância lateral em relação à linha média, eixo $x$, das perfurantes do lado esquerdo, foi menor nas mulheres. Não conseguimos atribuir este achado a nenhuma evidência anatômica durante a dissecação, sendo que esta diferença deve desaparecer com um maior número de perfurantes dissecadas, já que apenas 33\% das perfurantes foram dissecadas em cadáveres do sexo feminino.

Os calibres arteriais encontrados variaram de 0,3 a 1,7 $\mathrm{mm}$, com uma média de $0,68 \mathrm{~mm}$ sem variações significativas em relação ao lado ou o sexo. Acreditamos que estes valores sejam subestimados quando comparados aos achados in vivo, devido à condições de esvaziamento vascular que ocorre nos cadáveres, conforme encontrado por Munhoz et al e Hamdi et al, que relataram diferença de aproximadamente $32 \%$ nos calibres das IMAP de $2^{\circ}$ e $3^{\circ}$ EIC em cadáveres com relação aos achados in vivo. ${ }^{29,81} \mathrm{O}$ trabalho de Schmidt et al descreve calibres decrescentes das perfurantes IMAP à medida que distanciam-se caudalmente da clavícula, tendo estudado as perfurantes até $0 \quad 5^{\circ}$ EIC. Diversos autores descreveram um maior diâmetro da segunda e terceira perfurantes, sendo que há 
também um aumento no calibre da quarta perfurante no sexo feminino, devido à colaboração desta na irrigação da glândula mamária. ${ }^{30,35,36,60}$ A perfurante SSEA representa a perfurante IMAP do $7^{\circ}$ EIC, sendo a primeira perfurante que emerge da fáscia do reto abdominal caudal ao fim do gradeado costal. Vesely et al descreve o uso de tal perfurante para reconstruções torácicas e Kalender et al relatou seu uso para reconstruções mamárias de sequelas de queimadura e de radiodermite, em 4 pacientes, com rotação em hélice de retalhos fasciocutâneos baseados na perfurante SSEA. Os retalhos deste autor variaram de $6 \times 11$ a $8 \times 13 \mathrm{~cm} .{ }^{27,32}$ Assim, perfurantes com estes calibres representam perfurassomos capazes de perfundir ilhas de pele da redondeza, que podem atingir até a linha axilar anterior, para a dissecação de retalhos na prática clínica. ${ }^{37,38,46,82}$.

Em nossas dissecações todas as perfurantes SSEA continham uma artéria e duas veias de mesmo calibre, o que difere do que foi encontrado para as perfurantes do $2^{\circ}$ e $3^{\circ}$ EIC onde a veia tem calibres até 2 vezes maior. ${ }^{32,36,38,46,83-85}$ Além disso, todas as perfurantes eram acompanhadas de ramos nervosos cutâneos intercostais anteriores, que conferem sensibilidade à ilha de pele do retalho e condiz com os achados de $\mathrm{Yu}$ et al e Vesely et al. ${ }^{30,32}$ A localização das perfurantes foi discretamente diferente dos achados de Uemura, que dissecou 15 perfurantes em 8 cadáveres e estas localizavam-se, em média, a 3,5 cm da linha alba e 2,6 cm da margem costal inferior; enquanto que, no presente trabalho, a distância média das 114 perfurantes dissecadas em 35 cadáveres foi de $2,5 \mathrm{~cm}$ e $4,9 \mathrm{~cm}$, respectivamente. $^{86}$

Apesar de não encontrarmos correlação dos calibres das perfurantes com sua localização, idade, peso, e altura; foi encontrada correlação positiva entre calibres e localização nos eixos x e y para as perfurantes em relação ao lado, o que representa uma uniformidade nos achados (Tabela 3).

\subsubsection{Retalho osteomiocutâneo baseado nos vasos torácicos internos}

O trabalho experimental pioneiro de Strauch et al descreveu o retalho pediculado de costela, mas bloqueou seu pleno desenvolvimento pela evolução desfavorável dos animais operados. ${ }^{48} \mathrm{~A}$ mortalidade, que ultrapassou $60 \%$, e as 
deiscências de feridas esternais, que aconteceram em todos os casos, desencorajaram a aplicação clínica da nova técnica, exceto por alguns poucos casos. $^{49,51,52}$ A esternotomia e a dissecação da costela realizados pelo autor geraram tórax instável nos cães ao separar a caixa torácica em 3 segmentos diferentes. Ele realizou esternotomia longitudinal e ressecou as sincondroses costais junto com o arco costal do retalho, fragmentando o tórax em 3 pedaços e gerando a instabilidade. Os animais evoluíram com pneumonia e deiscência esternal. Ketchum et al também desenvolveu uma técnica agressiva para dissecar o pedículo e levantar o retalho: esternotomia associada à fratura de todas as sincondroses do $1^{\circ}$ ao $6^{\circ}$ arco, até alcançar a sétima costela, que foi inclusa no retalho. ${ }^{49}$ Esta morbidade na dissecação do pedículo limita o uso do retalho pediculado nos vasos torácicos internos, porque os pacientes candidatos a este tipo de reconstrução, considerandose aqueles com doença oncológica de cabeça e pescoço, geralmente apresentam função pulmonar limítrofe pelo tabagismo prolongado. Por isto, para que o retalho pediculado de costela possa ser uma alternativa, é necessário desenvolver uma técnica menos mórbida de dissecação do pedículo.

O desenvolvimento da técnica de dissecação para isolamento do pedículo baseou-se em trabalhos previamente desenvolvidos que utilizaram a esternotomia longitudinal como via de acesso para dissecação do pedículo torácico interno. ${ }^{48,51}$ No entanto, na dissecação cadavérica, a dificuldade técnica de realização da esternotomia e dissecação do pedículo abaixo do esterno impediu o uso desta técnica. Nos cadáveres, o acesso ao pedículo torácico interno foi feito através da ressecção das sincondroses e cartilagens costais, enquanto que, nos casos clínicos, foi utilizado acesso por esternotomia em "L" invertido, com preservação da integridade do manúbrio. Ambos acessos permitem visualização direta do pedículo em seu trajeto mediastinal extrapleural, localizada entre as costelas, músculos intercostais e o músculo transverso do tórax. ${ }^{30,32,36}$ Profundamente ao bloco cartilaginoso da sincondrose da $5^{\underline{a}}, 6^{\underline{a}}$ e $7^{\underline{a}}$ é onde a artéria torácica interna ramifica em vasos costomarginais e musculofrênicos. ${ }^{31,32,38}$ A partir daí, foi possível isolar os vasos intercostais para $6^{\underline{a}}$ e $7^{\underline{a}}$ costelas. A extensão caudal da artéria torácica interna consiste na artéria epigástrica profunda superior, que emite a SSEA e vai irrigar o músculo reto abdominal e a pele sobrejacente, que são inclusos no pedículo e compõe o retalho osteomiocutâneo. 
A classificação em três tipos de retalho de acordo com a vascularização do sexto arco costal foi baseada fundamentalmente na capacidade de dissecar os vasos intercostais para a sexta costela. A irrigação dos arcos costais é sempre dupla, com vasos intercostais de semelhante calibre, sendo que o vaso intercostal principal percorre a margem inferior do arco costal e emite um ramo colateral para a margem superior da costela inferior ${ }^{87}$ (Fig. 25). Sendo assim, no tipo III, em que há uma irrigação dupla para o sexto arco costal, foi possível dissecar ambos os vasos intercostais que irrigam a sexta costela, das margens superior e inferior. Nos tipos I e II, apenas um dos vasos foi dissecado.

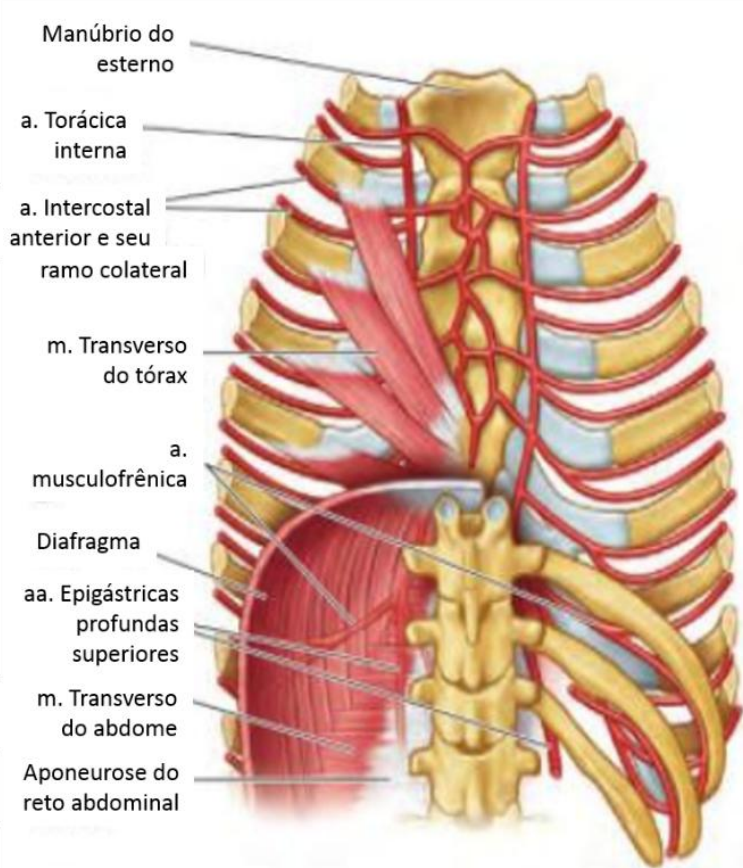

A. Vista Posterior

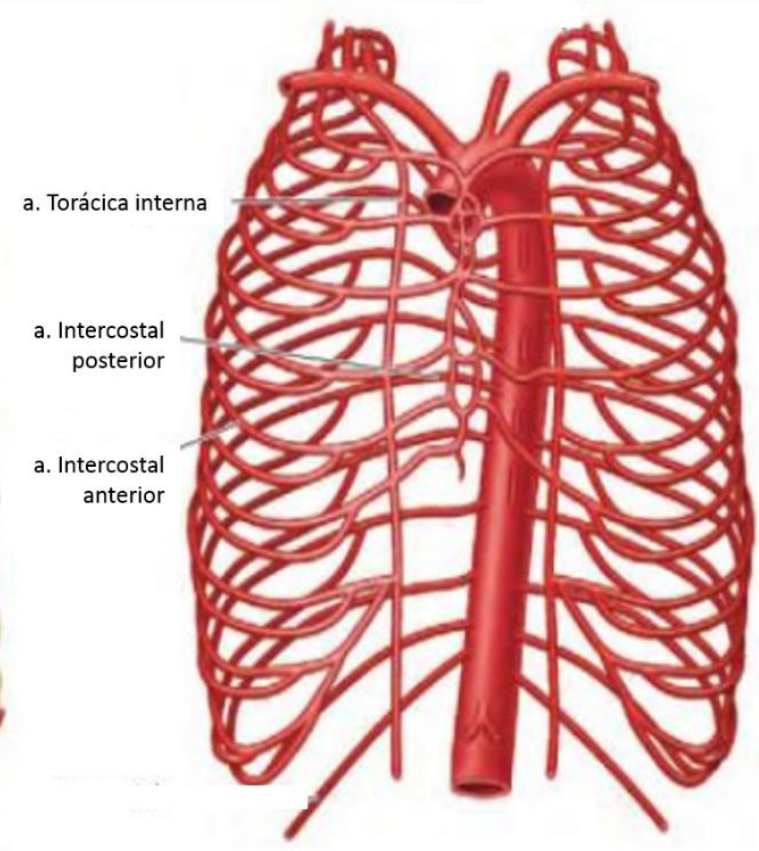

B. Vista Anterior

Figura 25: Irrigação dos arcos costais por via dupla com ramos arteriais nas margens superior e inferior das costelas. A: Vista posterior interna da face anterior do tórax. B: Vista anterior dos vasos sanguineos arteriais do tórax. Extraído de Moore $K L$ et al. Clinically oriented anatomy. 6th ed. Philadelphia: Wolters Kluwer Health/Lippincott Williams \& Wilkins; 2010.

Alguns autores relataram diferenças nos calibres dos vasos torácicos internos, sendo maior à direita, além de existir variação na frequência e no número 
de veias comitantes. ${ }^{32,36,38,88,89}$ Em nossa casuística não houve diferença nos calibres dos vasos torácicos internos em relação ao lado ou ao sexo. Todas as dissecações apresentaram pedículos torácicos internos com uma artéria e pelo menos uma veia comitante. Há viés de mensuração das medidas feitas em cadáver com relação às medidas realizadas in vivo. ${ }^{29,81}$ Acreditamos que as medidas em cadáver são subestimadas pelo esvaziamento vascular pós mortem, principalmente as medidas venosas.

A dissecação do retalho osteomiocutâneo pediculado nos vasos torácicos internos foi possível em ambos os lados de todos os cadáveres dissecados. A técnica de isolamento do pedículo é trabalhosa, mas reprodutível e a irrigação da sexta e sétima costelas é constante e previsível. Em todas as dissecações foram isolados os pedículos para sexta e sétima costelas e músculo reto abdominal. $\mathrm{O}$ comprimento do pedículo ósseo, que poderia ser o limitante para alcançar a topografia de cabeça e pescoço, foi semelhante para sexta ou sétima costela e foi possível testar o arco de rotação até seguimento cefálico em todas as dissecações. O comprimento do pedículo, desde o ponto pivô na margem inferior da primeira costela até a entrada do vaso intercostal na sexta ou sétima costela, variou de 17,8 cm, para sexta costela à esquerda (menor valor de D5/D5'), a 21,6 cm, para sétima costela à direita (maior valor de D4, tabela 4). Com este comprimento, o alcance do osso chegou até maxila e mandíbula em todas as dissecações. Não houve diferença significativa na análise pareada dos comprimentos dos pedículos ósseos da sexta e sétima costelas, e também não houve diferença em relação ao lado considerado. Este achado aumenta a versatilidade do retalho pois permite escolher o lado e a costela cujas dissecações forem mais favoráveis.

Em relação ao componente miocutâneo do reto abdominal, a sua dissecação é bem mais simples que a dissecação dos pedículos ósseos e seu arco de rotação é muito amplo. Também medido a partir da margem inferior da primeira costela bilateralmente, verificamos que o comprimento mínimo do pedículo para o reto abdominal (medidas D6) foi de $15,5 \mathrm{~cm}$; e o máximo, de $25 \mathrm{~cm}$. Já o comprimento final do pedículo na porção mais caudal do músculo, onde localizam-se os vasos DIEA (medidas D7), variou de 43 a $56 \mathrm{~cm}$. Estes comprimentos permitiram alcance do componente miocutâneo até região occipital em todas as dissecações, para ambos os lados. A presença dos vasos DIEA na extremidade distal do músculo reto abdominal confere a possibilidade de anastomose vascular para acoplamento de um 
retalho livre em série, ou supercarregamento do retalho pediculado na torácica interna (Fig. 26).
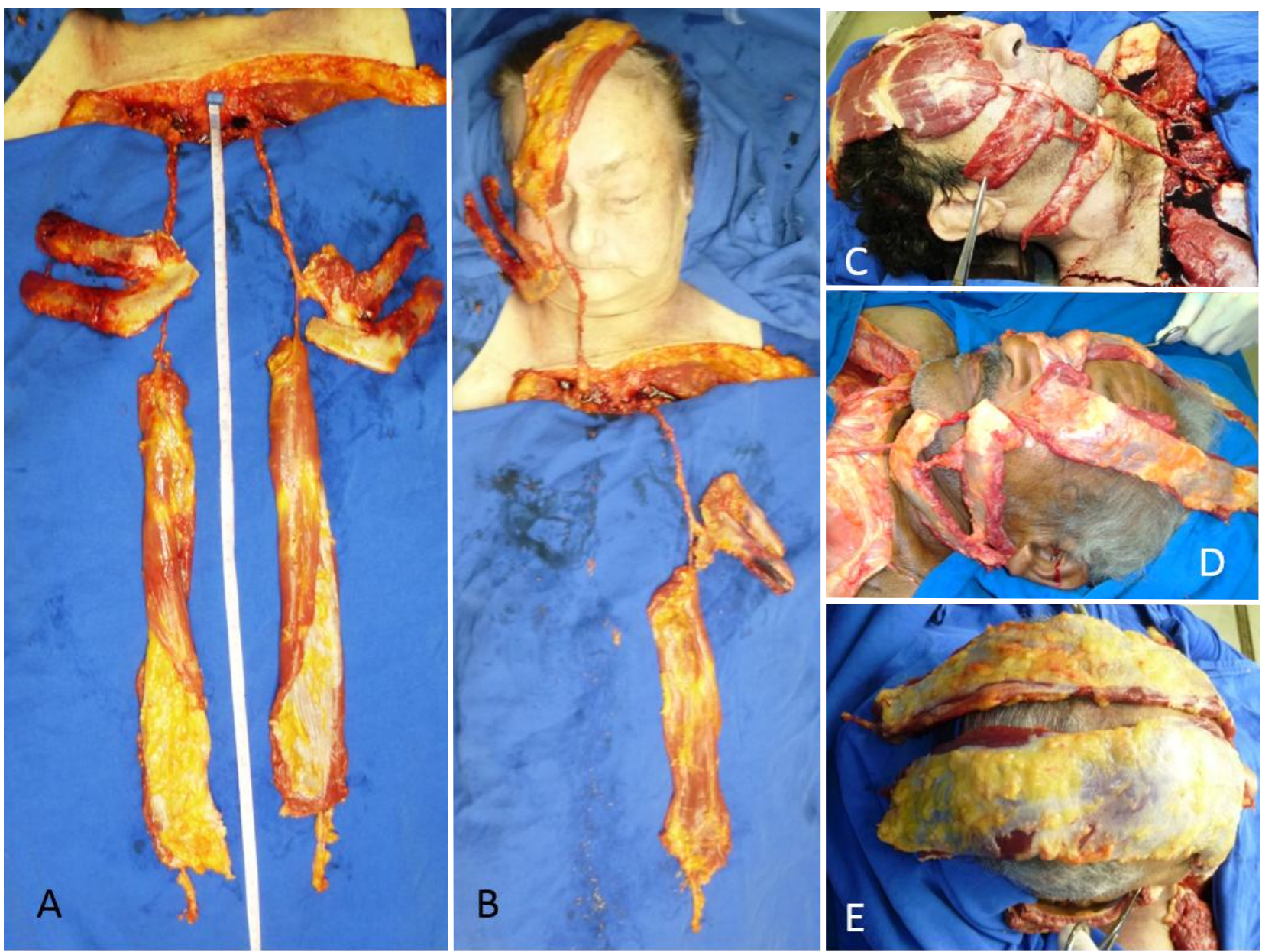

Figura 26: Arco de rotação do retalho osteomiocutâneo pediculado na torácica interna. A: retalho dissecado bilateralmente com sexta e sétima costelas e reto abdominal. B: rotação de retalho à direita para o seguimento cefálico. C e D: alcance da sexta e sétima costelas até maxila e mandíbula. $\mathbf{E}$ : músculo reto abdominal alcança até o occipício. 


\subsection{Aplicabilidade Clínica}

\subsubsection{Indicações cirúrgicas}

As indicações precisas para utilização da nova técnica cirúrgica, com uso de um novo retalho, consistem exatamente da impossibilidade de uso de outras técnicas, incluindo retalhos loco-regionais de uso rotineiro, seja por comprometimento do pedículo vascular ou pelo próprio uso prévio destes retalhos. Os pacientes candidatos são aqueles que, em relação às lesões de cabeça e pescoço:

a) encontram-se em situação excepcional na prática clínica com escassez de vasos receptores cervicais adequados, geralmente com múltiplas recidivas e tentativas anteriores de reconstrução não bem sucedidas, ou pela presença de linfadenectomia cervical radical bilateral;

b) tenham feito radioterapia e apresentem lesões tissulares radioinduzidas, como endarterite obliterante, dermatite e osteorradionecrose;

c) apresentem defeitos complexos, incluindo mucosa, partes moles, osso e cobertura cutânea, que necessitem retalhos compostos para reconstituição funcional e estética a fim de reinseri-los no convívio social;

d) Não possuam vasos receptores cervicais adequados à uma transferência de retalho livre comprovado por angiotomografia.

\subsubsection{Casos Clínicos}

A técnica cirúrgica desenvolvida no laboratório de anatomia teve que ser modificada para minimizar a morbidade na área doadora. A ressecção escalonada 
de todas as sincondroses costoesternais para acessar o pedículo torácico interno desestrutura a arquitetura da cavidade torácica, gerando dor, instabilidade e complicações da ferida e respiratórias. Todos casos em cães operados por Strauch et al apresentaram complicações de área doadora esternal com deiscências e pneumonia em todos os animais, fatal em $60 \%$ deles. Com a dissecação do componente ósseo do retalho, gerou-se um arcabouço torácico instável e dividido em três partes diferentes. ${ }^{48}$ A evolução dos animais neste trabalho desencorajou os cirurgiões plásticos e poucos relatos de costela pediculada na artéria torácica interna podem ser encontrados na literatura. Dois autores acessaram os vasos torácicos internos através das sincodroses, fraturando-as ou ressecando-as. ${ }^{49,52}$ Outro utilizou a esternotomia convencional. ${ }^{51}$ Eles não relatam complicações de área doadora.

Cinco pacientes foram operados no Hospital das Clínicas da Universidade de São Paulo no período de julho de 2009 a junho de 2013. Eles apresentavam ausência de vasos receptores no pescoço devido a múltiplas recidivas, múltiplas ressecções e múltiplas reconstruções, esvaziamento cervical linfonodal e radioterapia. Os pacientes submetidos à cirurgia foram avaliados, de acordo com a complexidade do defeito e dos componentes faciais envolvidos, quanto à possibilidade de reconstrução com retalhos locorregionais convencionais e submetidos à avaliação radiológica com angiotomografia para avaliar os vasos receptores cervicais e disposição dos vasos torácicos internos com suas ramificações (Fig 27). Em todos os casos, retalhos locorregionais convencionais estavam ausentes ou eram insuficientes, e não havia vasos receptores cervicais adequados para transferência microcirúrgica segura.

Todos os pacientes assinaram termo de consentimento livre e esclarecido antes da cirurgia. Todos eram do sexo masculino, entre 31 e 68 anos e apresentavam sequelas faciais e orofaríngeas com tentativas de reconstrução que, ou foram totalmente perdidas, com média de 1,2 perdas de retalho livre por paciente, ou foram insuficientes. A média de retalhos locais, incluindo retalho de peitoral maior, deltopeitoral e supraclavicular foi de 2,7 por paciente. Eles passaram, em média, por 2,3 ressecções tumorais e 5,4 cirurgias prévias. O cinco pacientes foram reconstruídos com retalhos pediculados da torácica interna com pedículo estendido. Quatro deles foram reconstruídos com retalhos osteomiocutâneos contendo a sétima costela em 2, e a sexta em outros 2; duas ilhas de pele, uma da região imediatamente acima do arco costal em 3 casos, ou individualizada da perfurante da 
SSEA em 2 dos casos, sendo a segunda ilha de pele um retalho miocutâneo vertical de reto abdominal.

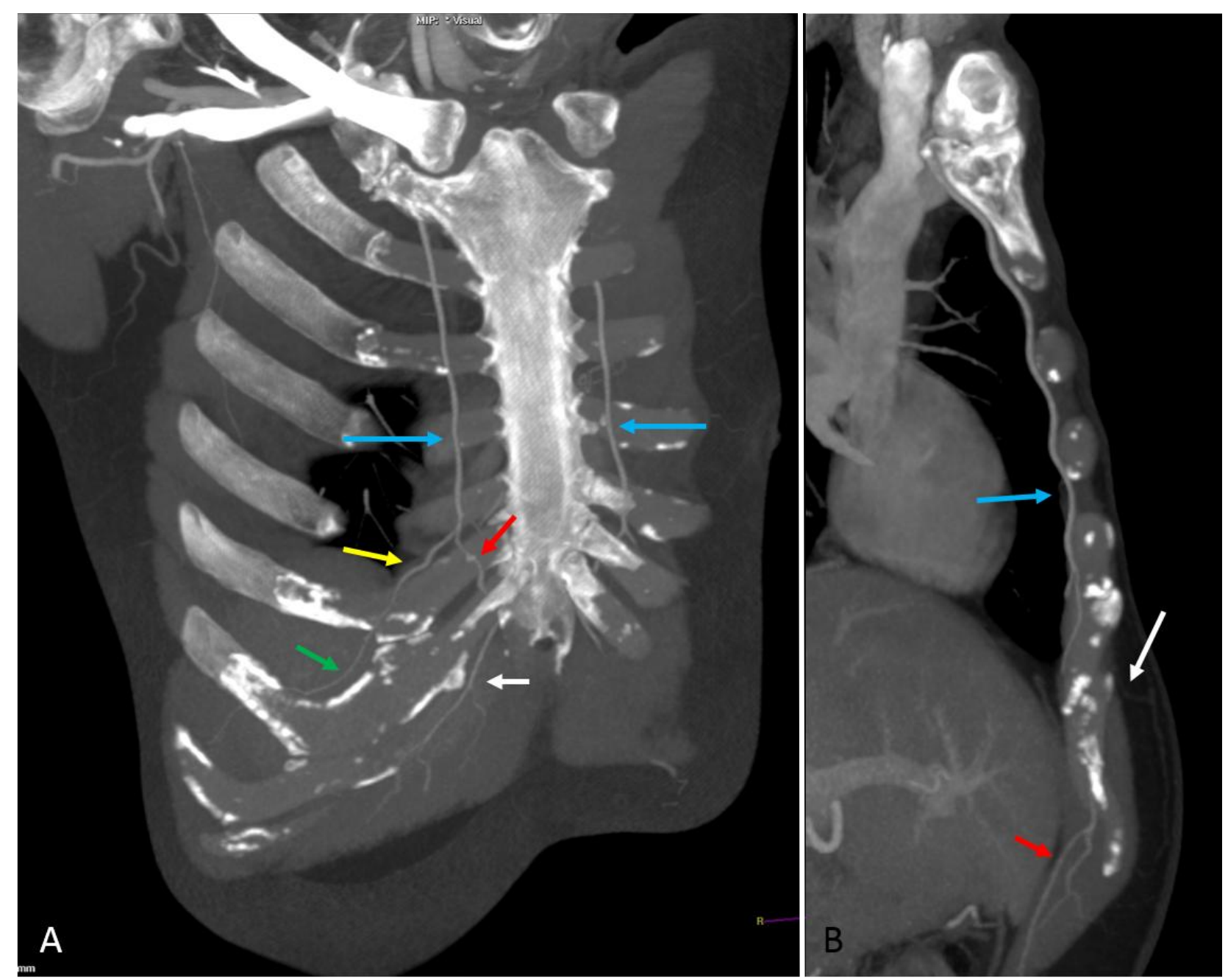

Figura 27: Angiotomografia dos vasos torácicos internos para planejamento pré-operatório do retalho. A: visão oblíqua anterior de reconstrução planar com visualização de vasos torácicos internos bilateralmente (setas azuis), e, à direita, vasos musculofrênico (seta amarela), artéria epigástrica profunda superior (DSEA, seta vermelha), artéria intercostal para sétima costela (seta verde), artéria perfurante epigástrica superior superficial (SSEA, seta branca). B: visão lateral de vaso torácico lateral acompanhando o relevo dos arcos costais (seta azul), DSEA (seta vermelha), e SSEA (seta branca).

Nestes cinco casos operados, optou-se por uma esternotomia em "L invertido" na altura do primeiro espaço intercostal do lado dissecado. ${ }^{56} \mathrm{~A}$ dissecação dos vasos torácicos internos foi por visualização direta. Com este acesso, mantém-se a estrutura da porção superior da caixa torácica e a integridade do manúbrio, 
protegendo o mediastino de uma contaminação pelas secreções oriundas da traqueostomia. Além disso, esta esternotomia permite acesso direto ao ponto pivô do pedículo, na margem inferior da primeira costela. O pedículo foi posicionado no subcutâneo cervical através de incisões quebradas, com distância de segurança de $3 \mathrm{~cm}$ do traqueostoma.

A ressecção do componente ósseo do retalho, composto pela sexta ou sétima costelas, restringiu-se à porção óssea do arco costal, o que não comprometeu o arcabouço inferior da caixa torácica por não violar as sincondroses.

Foi possível rodar o retalho para o segmento cefálico em todos os casos, com alcance suficiente para as reconstruções. Exceto por um caso em que houve discreta congestão devido à compressão do pedículo pela tensão do fechamento cutâneo, que foi tratado com abertura de alguns pontos, recuperando-se completamente; não houve qualquer sofrimento isquêmico ou venoso de todo ou parte do retalho.

Devido à gravidade dos pacientes, com intensa fibrose e sequelas de radioterapia, todos os casos apresentaram deiscências e fístulas salivares menores, tratadas com desbridamento e ressutura ou reavanço do retalho, com fechamento completo numa média de 21 dias.

Devido à abertura da cavidade pleural do lado da ressecção costal, os pacientes receberam um dreno torácico em selo d’água por, em média, 5,6 dias. Também foram drenados, com drenos de sucção, o mediastino e a região cervical por uma média de 7,1 e 11,3 dias respectivamente. As áreas doadoras costais, esternais e abdominais foram fechadas primariamente em todos os casos, com uso de tela macroporosa de polipropileno em abdome e no defeito torácico costal. Não houve qualquer tipo de complicação em relação às áreas doadoras, exceto pela presença de um sinus esternal em um paciente, que foi resolvido com a retirada do material de síntese. O esterno manteve-se estável em todos os pacientes. Boa parte dos pacientes com defeitos complexos oromandibulares apresentam gastrostomia e, por isso, houve predominância de escolha do lado direito para realização dos retalhos pediculados nos vasos torácicos internos. Os pacientes receberam alta com 33,6 dias em média.

Os retalhos pediculados nos vasos torácicos internos não tiveram qualquer tipo de sofrimento ou necrose (Figs 28 e 29). 


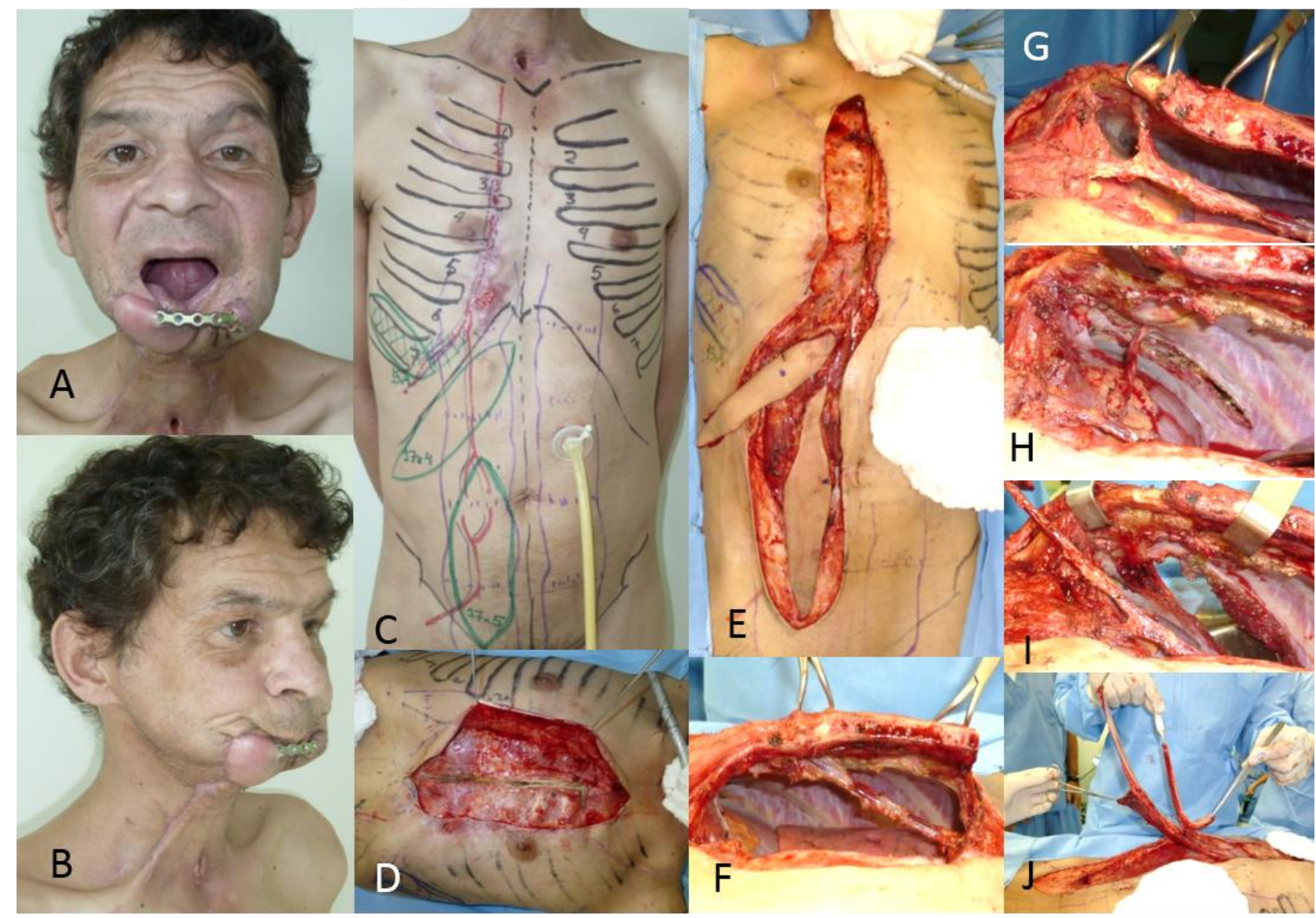

Figura 28: Paciente n. 2, 42 a. A e B: defeito assoalho oral anterior com mandíbula e pele do mento. Placa de reconstrução exposta e retalho peitoral. C: marcação retalho osteomiocutaneo pediculado na torácica interna com duas ilhas de pele. D: esternotomia em "L invertido". E: retalho miocutâneo reto abdominal com duas ilhas de pele levantado. F: pedículo torácico interno sendo descolado da face posterior do esterno. G: bifurcação do pedículo torácico interno em DSEA e músculo-frênica. H: músculo-frênica e intercostal indo para sexta costela. I: defeito na parede torácica pós ressecção da sexta costela. J: retalho miocutâneo levantado. 


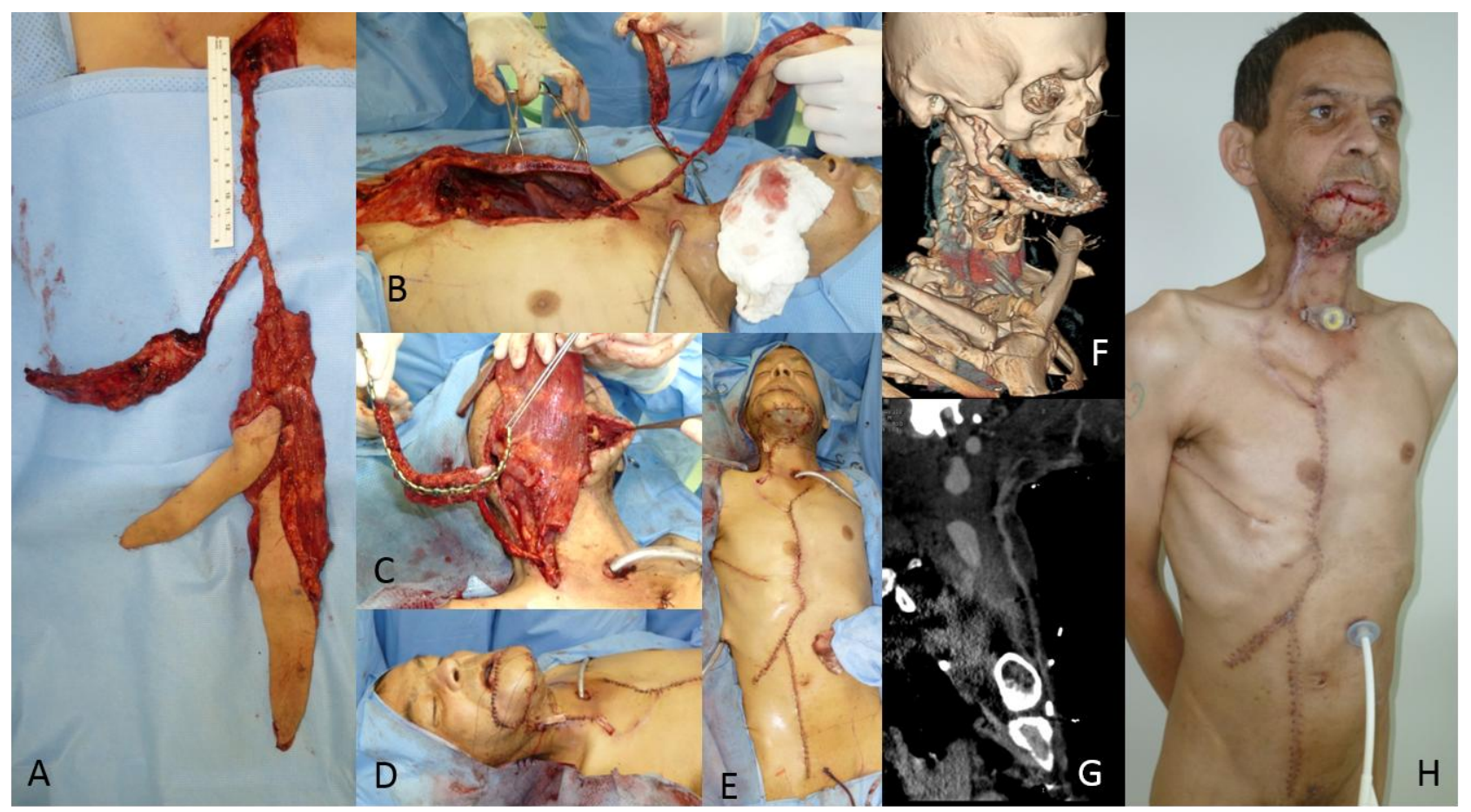

Figura 29: Paciente número 2, 42 a. A: retalho osteomiocutâneo pediculado na torácica interna. B: rotação do retalho através da esternotomia em "L invertido" para segmento cefálico. C: montagem do retalho com reconstrução do assoalho oral, moldagem da costela para defeito mandibular, posicionamento de músculo para preenchimento. D: aspecto final com recuperação da projeção de mento e segunda ilha de pele para reconstrução do defeito de pele. E: aspecto final da área doadora. F: reconstrução tridimensional de tomografia mostrando boa integração da costela. G: angiotomografia evidencia pedículo torácico interno no seu percurso subcutâneo pré-clavicular até porção cervical superior. H: pós operatório 3 meses com recuperação da continência e alimentação via oral, e adequada capacidade fonatória, em programação de reabilitação odontológica.

As tabelas 5 e 6 discriminam o diagnóstico e condições dos pacientes com os tratamentos e reconstruções prévias, bem como o defeito reconstruído pelos retalhos pediculados nos vasos torácicos internos. A evolução e seguimento também estão resumidos. 


\begin{tabular}{|c|c|c|c|c|c|c|c|}
\hline Pcte & $\begin{array}{c}\text { Doença de } \\
\text { Base }\end{array}$ & $\begin{array}{l}\text { Está- } \\
\text { dio }\end{array}$ & $\begin{array}{l}\text { Comorbi- } \\
\text { dades } \\
\text { e detalhes }\end{array}$ & $\begin{array}{l}\text { Trata- } \\
\text { mentos } \\
\text { prévios }\end{array}$ & $\begin{array}{c}\text { Reconstru- } \\
\text { ções } \\
\text { Prévias }\end{array}$ & $\begin{array}{l}\text { Adju- } \\
\text { vância }\end{array}$ & Cirurgia atual \\
\hline $\begin{array}{c}1 . \\
\text { RSN, } \\
\text { M, } \\
31 a\end{array}$ & $\begin{array}{l}\text { Sarcoma } \\
\text { Pleomór- } \\
\text { fico de } \\
\text { base de } \\
\text { crânio }\end{array}$ & $\begin{array}{c}\text { Grau } \\
\text { III }\end{array}$ & $\begin{array}{l}\text { Desnutrição } \\
\text { gastrostomia }\end{array}$ & $\begin{array}{c}\text { RTX } \\
\text { exclusiva } \\
\text { campo } \\
\text { estendido }\end{array}$ & não fez & $\begin{array}{l}\text { QTXe } \\
\text { RTX }\end{array}$ & $\begin{array}{c}\text { Mandibulo- } \\
\text { maxilectomia E } \\
\text { com ressecção } \\
\text { de pele da } \\
\text { bochecha E, } \\
\text { cavidade oral e } \\
\text { nasal + rino e } \\
\text { orofaringe }\end{array}$ \\
\hline $\begin{array}{c}2 . \\
\text { RGS, } \\
\text { M, } \\
42 a\end{array}$ & $\begin{array}{c}\text { CEC } \\
\text { gengiva }+ \\
\text { mandíbula } \\
\text { anterior e } \\
\text { pele do } \\
\text { mento }\end{array}$ & $\begin{array}{l}\text { T4N1 } \\
\text { MX }\end{array}$ & $\begin{array}{l}\text { Tabagismo } \\
\text { etilismo } \\
\text { tuberculose } \\
\text { gastrostomia }\end{array}$ & $\begin{array}{c}\text { PGM } \\
\text { anterior } \\
\text { segmentar } \\
\text { e pele do } \\
\text { queixo + } \\
\text { ECRM D e } \\
\text { SOH E }\end{array}$ & $\begin{array}{c}\text { Retalho } \\
\text { miocutâneo } \\
\text { peitoral } \\
\text { + placa } \\
\text { reconstrução } \\
\text { mandibular }\end{array}$ & $\begin{array}{l}\text { QTX e } \\
\text { RTX }\end{array}$ & $\begin{array}{c}\text { Retirada de } \\
\text { placa e } \\
\text { desbridamento }\end{array}$ \\
\hline $\begin{array}{c}3 . \\
C A \\
M \\
54 a\end{array}$ & $\begin{array}{c}\text { CEC } \\
\text { gengiva + } \\
\text { mandíbula } \\
\text { anterior }\end{array}$ & $\begin{array}{c}\text { T4N2c } \\
\text { MX }\end{array}$ & $\begin{array}{c}\text { Tabagismo } \\
\text { etilismo } \\
\text { gastrostomia }\end{array}$ & $\begin{array}{c}\text { PGM } \\
\text { anterior } \\
\text { segmentar } \\
+ \text { ECRM } \\
\text { bilateral }\end{array}$ & $\begin{array}{l}\text { Perdeu duas } \\
\text { fíbulas livres }\end{array}$ & $\begin{array}{l}\text { QTX e } \\
\text { RTX }\end{array}$ & $\begin{array}{c}\text { Reconstituição } \\
\text { do } \\
\text { defeito ósseo e } \\
\text { de cavidade } \\
\text { oral }\end{array}$ \\
\hline $\begin{array}{c}4 . \\
\text { VOG } \\
M, \\
68 a\end{array}$ & $\begin{array}{l}\text { CEC } \\
\text { trígono } \\
\text { retromolar } \\
\text { E }\end{array}$ & $\begin{array}{c}\text { T4N2a } \\
\text { M1 }\end{array}$ & $\begin{array}{c}\text { Tabagismo } \\
\text { etilismo } \\
\text { gastrostomia } \\
\text { úlcera } \\
\text { gástrica }\end{array}$ & $\begin{array}{c}\text { PGM } \\
\text { posterior E } \\
\text { segmentar } \\
+ \text { ECRM } \\
\text { bilateral }\end{array}$ & $\begin{array}{l}\text { Peitoral, } \\
\text { supra- } \\
\text { clavicular, } \\
\text { deltopeitoral } \\
\text { e retalho de } \\
\text { língua }\end{array}$ & $\begin{array}{l}\text { QTX e } \\
\text { RTX }\end{array}$ & $\begin{array}{c}\text { Reconstituição } \\
\text { do } \\
\text { defeito } \\
\text { oromandibular }\end{array}$ \\
\hline $\begin{array}{c}\mathbf{5} . \\
\text { CEO, } \\
\mathrm{M}, \\
54 \mathrm{a}\end{array}$ & CEC língua & $\begin{array}{c}\text { T4aN2 } \\
\text { bMx }\end{array}$ & $\begin{array}{l}\text { Tabagismo } \\
\text { etilismo } \\
\text { drogadição } \\
\text { gastrostomia }\end{array}$ & $\begin{array}{c}\text { PGM } \\
\text { anterior } \\
\text { segmentar } \\
+ \text { ECRM D } \\
\text { e SOH E }\end{array}$ & $\begin{array}{c}\text { Perdeu uma } \\
\text { fíbula + ALT } \\
\text { com placa }\end{array}$ & $\begin{array}{l}\text { QTX e } \\
\text { RTX }\end{array}$ & $\begin{array}{c}\text { Reconstituição } \\
\text { do } \\
\text { defeito } \\
\text { oromandibular }\end{array}$ \\
\hline
\end{tabular}

Tabela 5: Descrição dos pacientes submetidos à reconstrução com retalho osteomiocutâneo pediculado nos vasos torácicos internos. Estão relacionadas as condições pré-existentes, histologia inicial do tumor, comorbidades, tratamento prévio com adjuvâncias, reconstruções prévias e proposta cirúrgica atual antes da reconstrução com o retalho descrito. 


\begin{tabular}{|c|c|c|c|c|c|c|c|}
\hline Pcte & Defeito & Reconstrução & $\begin{array}{l}\text { Compo- } \\
\text { sição do } \\
\text { retalho }\end{array}$ & $\begin{array}{l}\text { Complicações } \\
\text { e tratamento }\end{array}$ & $\begin{array}{l}\text { Intern } \\
\text { ação }\end{array}$ & $\begin{array}{l}\text { Evo- } \\
\text { lução }\end{array}$ & $\begin{array}{l}\text { Segui- } \\
\text { mento }\end{array}$ \\
\hline $\begin{array}{c}\text { RSN } \\
\text { M, } \\
31 \text { a }\end{array}$ & $\begin{array}{c}\text { Comunicação dura- } \\
\text { mater e cavidade oral e } \\
\text { nasal + } \\
\text { mandibulectomia, } \\
\text { maxilectomia E + pele } \\
\text { bochecha }\end{array}$ & $\begin{array}{l}\text { Imediata } \\
\text { Miocutâneo } \\
\text { VRAM } \\
\text { pedículo } \\
\text { estendido }\end{array}$ & VRAM à E & $\begin{array}{c}\text { Fístula } \\
\text { orocutânea } \\
(\mathrm{OC}): \\
\text { ressutura } \\
\text { AD: sem } \\
\text { complicações }\end{array}$ & $\begin{array}{l}45 \\
\text { dias }\end{array}$ & $\begin{array}{l}\text { dieta } \\
\text { oral e } \\
\text { fona- } \\
\text { ção }\end{array}$ & $\begin{array}{l}11 \\
\text { meses, } \\
\text { óbito por } \\
\text { recidiva } \\
\text { tumoral }\end{array}$ \\
\hline $\begin{array}{c}2 . \\
\text { RGS } \\
\text { M, } \\
42 \text { a }\end{array}$ & $\begin{array}{c}\text { mandíbula ângulo a } \\
\text { ângulo, cavidade oral e } \\
\text { pele do mento, + } \\
\text { incontinência oral }\end{array}$ & $\begin{array}{c}\text { Tardia } \\
\text { Osteomio- } \\
\text { cutâneo } \\
\text { pediculado na } \\
\text { torácica int. d }\end{array}$ & $\begin{array}{l}6^{\text {a }} \text { costela, } \\
2 \text { ilhas de } \\
\text { pele: } \\
\text { SSEA e } \\
\text { VRAM }\end{array}$ & $\begin{array}{c}\text { Fístula } \\
\text { orocutânea: } \\
\text { ressutura } \\
\text { AD: sem } \\
\text { complicações }\end{array}$ & $\begin{array}{l}28 \\
\text { dias }\end{array}$ & $\begin{array}{l}\text { dieta } \\
\text { oral e } \\
\text { fona- } \\
\text { ção }\end{array}$ & $\begin{array}{l}12 \\
\text { meses, } \\
\text { óbito por } \\
\text { recidiva } \\
\text { tumoral }\end{array}$ \\
\hline $\begin{array}{l}3 . \\
\mathrm{CA} \\
\mathrm{M}, \\
54 \mathrm{a}\end{array}$ & $\begin{array}{l}\text { Deformidade Andy } \\
\text { Gump com defeito } \\
\text { mandibular de ângulo a } \\
\text { ângulo, e assoalho oral } \\
\text { + pele do mento }\end{array}$ & $\begin{array}{c}\text { Tardia } \\
\text { Osteomio- } \\
\text { cutâneo } \\
\text { pediculado na } \\
\text { torácica int. d }\end{array}$ & $\begin{array}{l}6^{\text {a }} \text { costela, } \\
2 \text { ilhas de } \\
\text { pele: perf } \\
\text { costais e } \\
\text { SSEA }\end{array}$ & $\begin{array}{l}\text { Deiscência } \\
\text { cervical: } \\
\text { ressutura } \\
\text { AD: sem } \\
\text { complicações }\end{array}$ & $\begin{array}{c}27 \\
\text { dias }\end{array}$ & $\begin{array}{l}\text { dieta } \\
\text { oral e } \\
\text { fona- } \\
\text { ção }\end{array}$ & $\begin{array}{l}3 \text { meses, } \\
\text { óbito por } \\
\text { complica } \\
\text { ções da } \\
\text { traqueo }\end{array}$ \\
\hline $\begin{array}{l}4 . \\
\text { VOG } \\
M, \\
68 \text { a }\end{array}$ & $\begin{array}{l}\text { Defeito lateral da } \\
\text { mandíbula e cavidade } \\
\text { oral à E extenso, } \\
\text { comunicado ao meio } \\
\text { externo e com língua } \\
\text { aderida }\end{array}$ & $\begin{array}{c}\text { Tardia } \\
\text { Osteomio- } \\
\text { cutâneo } \\
\text { pediculado na } \\
\text { torácica int. d }\end{array}$ & $\begin{array}{l}7^{\text {a }} \text { costela, } \\
2 \text { ilhas de } \\
\text { pele: perf } \\
\text { costais e } \\
\text { VRAM }\end{array}$ & $\begin{array}{l}\text { Neurop. facial: } \\
\text { conservador, } \\
\text { fístula OC: } \\
\text { ressutura } \\
\text { AD: sinus } \\
\text { esternal: } \\
\text { retirada fio aço }\end{array}$ & 25 & $\begin{array}{l}\text { dieta } \\
\text { oral e } \\
\text { fona- } \\
\text { ção } \\
\text { frustra }\end{array}$ & $\begin{array}{l}\text { PO } 20 \\
\text { meses } \\
\text { com } \\
\text { recidiva } \\
\text { em base } \\
\text { de crânio }\end{array}$ \\
\hline $\begin{array}{l}5 . \\
\text { CEO } \\
M, \\
48 \text { a }\end{array}$ & $\begin{array}{l}\text { Deformidade Andy } \\
\text { Gump com defeito } \\
\text { mandibular de ângulo a } \\
\text { ângulo, e assoalho oral } \\
\text { + pele do mento }\end{array}$ & $\begin{array}{c}\text { Tardia } \\
\text { Osteomio- } \\
\text { cutâneo } \\
\text { pediculado na } \\
\text { torácica int. d }\end{array}$ & $\begin{array}{l}7^{\text {a }} \text { costela, } \\
2 \text { ilhas de } \\
\text { pele: perf } \\
\text { costais e } \\
\text { VRAM }\end{array}$ & $\begin{array}{l}\text { Deiscência } \\
\text { cervical: } \\
\text { ressutura e } \\
\text { enxertia } \\
\text { AD: sem } \\
\text { complicações }\end{array}$ & $\begin{array}{l}35 \\
\text { dias }\end{array}$ & $\begin{array}{c}\text { dieta } \\
\text { oral e } \\
\text { fona- } \\
\text { ção } \\
\text { frustra }\end{array}$ & $\begin{array}{l}\text { PO } 14 \\
\text { meses. } \\
\text { Reabilita- } \\
\text { ção com } \\
\text { fono }\end{array}$ \\
\hline
\end{tabular}

Tabela 6: Descrição dos pacientes submetidos à reconstrução com retalho osteomiocutâneo pediculado nos vasos torácicos internos. Estão relacionadas o tipo do defeito, o momento da reconstrução, a composição do retalho, as complicações, o tempo de internação, a evolução e o seguimento. 
Houve completa integração e sobrevivência da costela comprovada por angiotomografia, com irrigação pelo pedículo torácico interno. Ambos os lados foram utilizados em diferentes pacientes e houve um paciente em que o pedículo cruzou para a face contralateral (paciente 4). Ao circundar a primeira costela e clavícula, o pedículo foi encurtado aproximadamente $6 \mathrm{~cm}$ em média, mas isto não comprometeu o alcance do retalho e evitou uma dissecação difícil e perigosa profundamente à clavícula (Fig. 30).

Após um média de 45 dias de pós-operatório, os pacientes já apresentavam recuperação da alimentação via oral e adequada reabilitação fonatória. Quanto à reabilitação odontológica, os pacientes iniciaram seguimento, mas nenhum deles conseguiu um período livre de doença que permitisse uma programação para uso de próteses. A costela é um osso fino e friável. Não é possível inferir que seja capaz de suportar implantodontia. Há uma possibilidade de intensificação da calcificação e fortalecimento da costela que esteja sob o stress mecânico da mandíbula. Para que isso ocorra, talvez seja necessário um longo período de tempo a fim de existir osteogênese e osteoindução da costela transferida. Nenhum paciente teve seguimento acima de 11 meses até agora. 


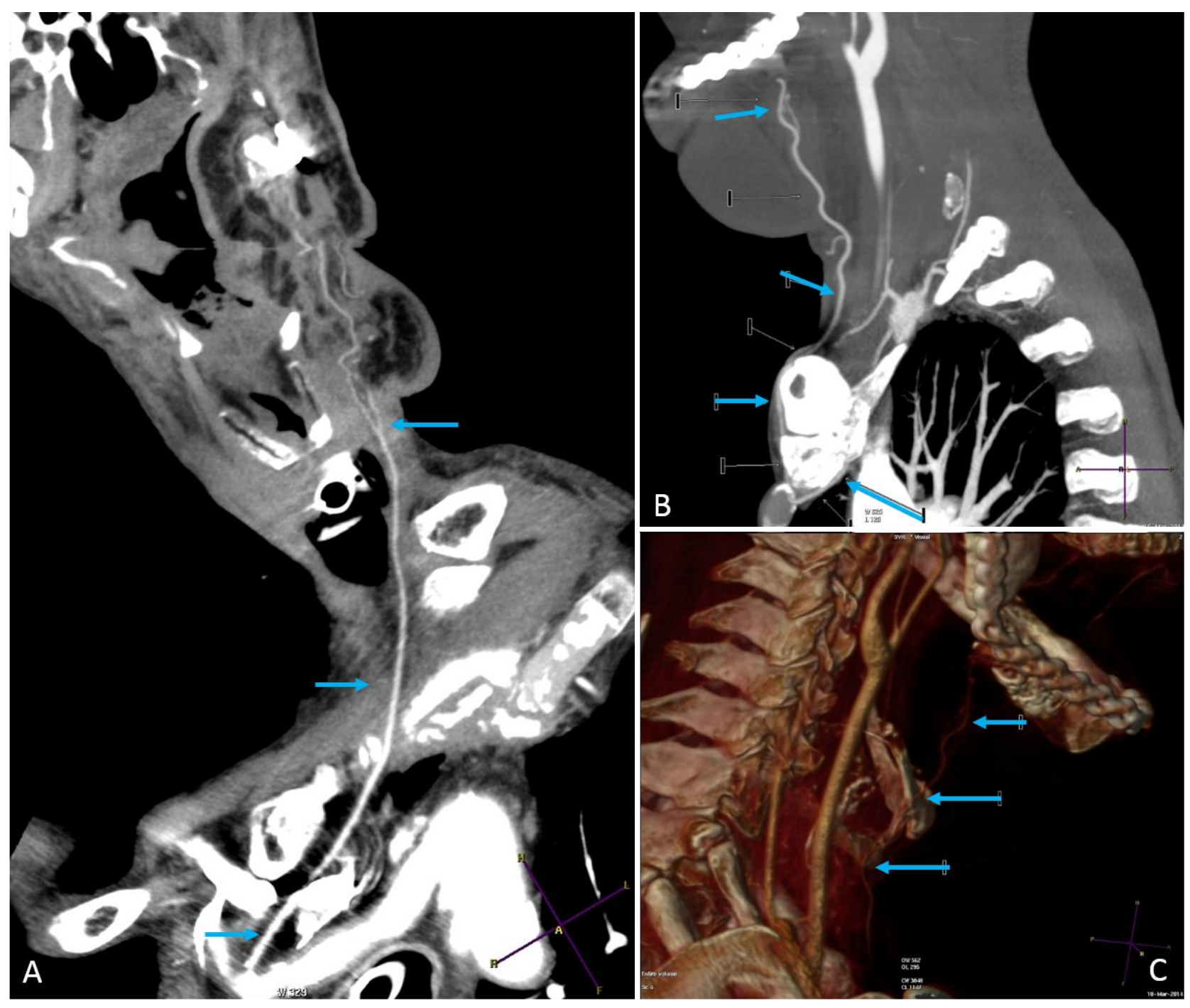

Figura 30: Reconstrução planar e tridimensional de angiotomografia pós-operatória. A: paciente n. 4. Pedículo torácico interno contorna primeira costela e clavícula à direita e cruza para face contralateral (setas azuis). B: paciente n. 3. Visão lateral que evidencia pedículo torácico interno (setas azuis) emergindo de artéria subclávia, contornando anterior e superficialmente primeira costela e clavícula para ascender no pescoço até porção de costela fixada aos cotos mandibulares. Partes moles de parte anterior do pescoço correspondem ao segmento miocutâneo de reto abdominal do retalho. C: paciente n. 5 . Visão oblíqua tridimensional com vaso torácico interno em seu trajeto superior no pescoço até arco costal fixado e integrado a coto mandibular. 
Embora a indicação do novo retalho proposto tenha sido feita em caráter excepcional, há algumas qualidades interessantes:

a) Possibilidade de levar para região da cabeça e pescoço, através de retalho pediculado, tecidos compostos vascularizados, que incluiriam osso e cartilagem, músculo e pele, viabilizando uma reconstrução funcional tridimensional sem a necessidade de transplante de retalho livre microcirúrgico. Assim, evita-se o risco associado às anastomoses em condições desfavoráveis, com vasos irradiados, em áreas dissecadas previamente, ou vasos transferidos de um sítio distante;

b) Área doadora distante do sítio a ser reconstruído, possibilitando a ação de duas equipes simultaneamente;

c) Pedículo vascular conhecido. A artéria torácica interna é utilizada há mais de 30 anos como doador para revascularizações do miocárdio sem comprometimento dos outros tecidos por ela irrigados; ${ }^{54,55}$

d) Componentes do retalho já utilizados em outros procedimentos de reconstrução consagrados na prática clínica. O componente miocutâneo de reto abdominal é utilizado rotineiramente para reconstruções mamárias; os arcos costais, tanto a porção óssea, como a porção cartilaginosa, são utilizados como enxerto para reconstruções craniofaciais; $;^{90-95}$

e) Sequelas em área doadora sem repercussão funcional. Esternotomia em "L invertido", para dissecação e acesso do pedículo, tem baixo índice de complicações como deiscência ou infecção, menor do que os 3\% das esternotomias medianas totais, e já é praticada rotineiramente nos procedimentos de cirurgia cardiovasculartorácica; ${ }^{56,96-100}$

f) O sítio reconstruído beneficia-se da qualidade da reconstrução com tecidos vascularizados compostos, oriundos de áreas não irradiadas, com pedículos vasculares longos e individualizáveis. 
6. Conclusão 
A partir das dissecações em cadáver e do uso clínico do retalho osteomiocutâneo baseado nos vasos torácicos internos, podemos concluir que:

1. Os retalhos pediculados nos vasos torácicos internos são constantes, podem conter componentes cutâneos, musculares e ósseo, e conferem uma alternativa nas reconstruções complexas de cabeça e pescoço para os casos de pescoço com ausência de vasos receptores e subtraídos de outras alternativas pediculadas.

2. O pedículo é extenso e acessível, com arco de rotação amplo que permite atingir com facilidade o segmento cefálico.

3. A frequência e previsibilidade de seus ramos e perfurantes permite planejar retalhos combinados com componentes osteomiocutâneos separados em pedículos secundários individuais, o que aumenta a versatilidade do retalho e oferece tecidos variados para reconstruções tridimensionais em cabeça e pescoço. 
7. Anexos 


\section{ANEXO A}

São Paulo, 08 de dezembro de 2010

IImo Sr.

Dr. Carlos Augusto Pascqualucci

DD Diretor do SVO

\section{Prezado Doutor}

Atendendo solicitação do médico pós-graduando Guilherme Cardinali Barreiro, informo que o projeto de pesquisa "Estudo da anatomia dos retalhos pediculados da artéria torácica interna e sua aplicabilidade na reconstrução de cabeça e pescoço", que será desenvolvido sob a orientação do Prof. Dr. Marcus Castro Ferreira, foi aprovado pela Comissão Assessora de Pesquisa do Departamento de Cirurgia, e encaminhado para aprovação da CAPPesq-Comissão de Ética para Análise de Projetos de Pesquisa do Hospital da Clinicas da Faculdade de Medicina da USP.

Atenciosamente,

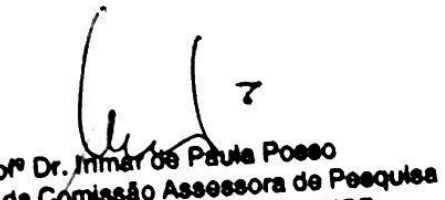

Prop Dr. Intmar o Padia Poeco

Preaidente da Comiseấo Assessora de Posp
Departamonto de Cirurgia da FMUSP 


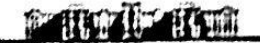 MEDICINA \\ TSP \\ COMITE DE ETICA EM PESQUISA}

\section{APROVAÇÃo}

O Comitê de Ética em Pesquisa da Faculdade de Medicina da Universidade de São Paulo, em sessão de 11/05/2011, APROVOU o Protocolo de Pesquisa no 025/11 intitulado: "ESTUDO DA ANATOMIA DOS RETALHOS PEDICULADOS DA ARTÉRIA TORÁCICA INTERNA E SUA APLICABILIDAde NA RECONSTRUÇão de CABEÇA E PESCOÇO.” apresentado pelo Departamento de CIRURGIA

Cabe ao pesquisador elaborar e apresentar ao CEPFMUSP, os relatórios parciais e final sobre a pesquisa (Resolução do Conselho Nacional de Saúde $n^{\circ}$ 196, de 10/10/1996, inciso IX.2, letra "c").

Pesquisador (a) Responsável: Marcus Castro Ferreira

Pesquisador (a) Executante: Guilherme Cardinali Barreiro

CEP-FMUSP, 11 de Maio de 2011.

Rlhamun.

Prof. Dr. Roger Chammas Coordenador

Comitê de Ética em Pesquisa 


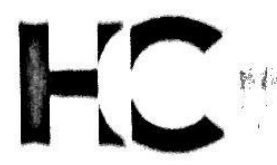

\section{APROVAÇÃO}

- Coordenador da Comissão de Ética para Análise de Projetos de Pesquisa - CAPPesq da Diretoria Clínica do Hospital das Clínicas da Faculdade de Medicina da Universidade de São Paulo, em 18/05/2011. APROVOU ad-referendum o Protocolo de Pesquisa-CEP-FMUSP $n^{\circ}$ 025/11. Inflifulado: "ESTUDO DA ANATOMIA DOS RETALHOS PEDICULADOS DA ARTÉRIA TORACICA INTERNA E SUA APLICABILIDADE NA RECONSTRUÇÃO DE CABEÇA E PESCOÇO ", apresentado pelo Departamento de Cirurgia.

Cabe ao pesquisador elaborar e apresentar à CAPPesq, os relatórlos parciais e final sobre a pesquisa (Resolução do Conselho Nacional de Saúde n 196, de 10/10/1996, inciso IX.2, letra "c").

Pesquisador (a) Responsável: PROF. DR. MARCUS CASTRO FERREIRA

Pesquisador (a) Executante: DR. GUILHERME CARDINALLI BARREIRO

CAPPesq, 18 de maio de 2011

PROF. DR. EUCLIDES AYRES DE CASTILHO

Coordenador

Comissão de Ética para Análise de

Projetos de Pesquisa - CAPPesq

Comissâ de Ettca para Análise de Projetos de Pesquisa do HCFMUSP da Diretoria Clinica do Hospital das Clinicas da Faculdade de Medicina da Universidade de Sáo Paulo Rua Ovidio Pires de Campos. 225, $5^{\circ}$ andar - CEP 05403010 - Sáo Paulo - SP Fone: 01130696442 Fax: 01130696492

e-mail: cappesq@hcnet.usp.br 


\begin{abstract}
ANEXO B
HOSPITAL DAS CLÍNICAS DA FACULDADE DE MEDICINA DA

UNIVERSIDADE DE SÃO PAULO - HCFMUSP

INSTITUTO DO CÂNCER DO ESTADO DE SÃO PAULO - ICESP
\end{abstract}

TERMO DE CONSENTIMENTO LIVRE E ESCLARECIDO

DADOS DE IDENTIFICAÇÃO DO SUJEITO DA PESQUISA OU RESPONSÁVEL LEGAL

1. NOME:

DOCUMENTO DE IDENTIDADE № :

SEXO:.$M \square F$

DATA NASCIMENTO:

ENDEREÇO

№

APTO:

BAIRRO:

CIDADE

CEP:

TELEFONE:

DDD

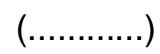

2.RESPONSÁVEL

LEGAL

NATUREZA

(grau

de

parentesco,

tutor,

curador

etc.)

DOCUMENTO DE IDENTIDADE SEXO: $M \square \quad F \square$

DATA NASCIMENTO.:

ENDEREÇO:

BAIRRO:

№

APTO:

CEP:

CIDADE

TELEFONE: DDD

..)..

\title{
DADOS SOBRE A PESQUISA
}

1. TíTULO DO PROTOCOLO DE PESQUISA: Estudo da anatomia dos retalhos pediculados da artéria torácica interna e sua aplicabilidade na reconstrução de cabeça e pescoço.

PESQUISADOR : Guilherme Cardinali Barreiro.

CARGO/FUNÇÃO: Médico Residente INSCRIÇÃO CONSELHO REGIONAL № 115813

UNIDADE DO HCFMUSP: ICESP

3. AVALIAÇÃO DO RISCO DA PESQUISA:

$$
\text { RISCO MÍNIMO }
$$

RISCO BAIXO
RISCO MÉDIO X

RISCO MAIOR 


\section{1 - Do estudo:}

Este estudo consiste na realização de cirurgia para reconstrução em cabeça e pescoço com o uso de novo retalho baseado no pedículo da artéria torácia interna. Essas informações estão sendo fornecidas para sua participação voluntária neste estudo, que visa a permitir a reconstrução cirúrgica. O senhor/a é candidato a participar deste estudo por apresentar condições desfavoráveis às técnicas habituais de reconstrução: já foram utilizados retalhos locais para reconstruções prévias, radioterapia prévia, linfadenectomia cervical, ausência de vasos cervicais receptores de retalho livre confirmado por exame radiológico, e defeito complexo que necessite múltiplos tecidos vascularizados.

\section{2 - Do procedimento:}

O procedimento consiste em utilização de retalhos pediculados baseados na artéria torácica interna através de acesso cutâneo em tórax e abdome. O senhor/a será submetido a tomografia com contraste para identificação dos vasos no pescoço, tórax e abdome para direcionar a cirurgia. Os exames de imagem serão obtidos conforme os Protocolos de Segurança do Instituto de Radiologia e mediante Consentimento Livre Esclarecido específico. Os exames serão realizados antes do procedimento cirúrgico e repetidos após para certificação, documentação e acompanhamento.

Cirurgia: o acesso aos vasos será pelo tórax no osso esternal. O pedículo vascular é isolado com os ramos para os diferentes retalhos necessários para reconstrução. Desta maneira, poderá incluir costela, pele e/ou músculo reto abdominal. O objetivo é obtenção de tecido compatível com as perdas em cabeça e pescoço para cobertura de feridas e reconstrução funcional.

A reconstrução em cabeça e pescoço se faz com retalhos locais, à distância ou livres, dependendo do tamanho e composição da lesão e da existência de vasos patentes receptores para o transplante microcirúrgico. No caso do senhor/a não há consenso para reconstrução pela ausência de vasos receptores ou retalhos locais. A técnica proposta é uma opção inovadora e permite reconstrução em casos sem outras opções.

\section{3 - Da preparação e seguimento:}

Pré operatório: O senhor/a será submetido a avaliação pré operatória completa por anestesiologista e/ou clínico, com todos exames que forem necessários. As consultas e todo o seguimento, incluindo os procedimentos dentro do centro cirúrgico, serão documentados em prontuário da instituição e através de gravações fotográficas, de áudio e de vídeo. Todo material obtido poderá ser utilizado para aulas e publicações científicas, mantendo-se a confidencialidade, a discrição, a ética e a boa conduta. A internação acontecerá no mínimo um dia antes da cirurgia.

Cirurgia: a anestesia é geral. $O$ ato anestésico seguirá os Protocolos de Segurança do Departamento de anestesiologia do HCFMUSP/ICESP e mediante Consentimento Livre Esclarecido específico. Serão utilizados sondagem da urina, drenos nos locais operados e tela para proteção do abdome.

Pós operatório: Inicialmente será na UTI até condições de alta para enfermaria. A alta hospitalar dependerá da recuperação individual. A dieta deverá seguir condições prévias do paciente e 
condições locais e sistêmicas do pós operatório, podendo ser através de sondagem naso-enteral. Após a alta, o senhor/a fará seguimento ambulatorial rotineiro.

\section{4 - Dos riscos e complicações:}

Cirurgia: Desconforto relacionado aos drenos e suas possíveis complicações, como infecções e hematomas. Alterações do formato do tórax pela retirada da costela e do abdome pela retirada do músculo. Risco de complicações em área doadora com infecções, deiscências, hematomas, seromas. Possibilidade de complicações na área receptora do retalho, em região de cabeça e pescoço, com deiscências, fístulas, infecção, extrusão de material de síntese, hematomas e seromas. Possibilidade de necrose de parte ou todo retalho, resultando em ferida com necessidade de novo procedimento cirúrgico para cobertura. Uso da artéria torácica interna que impede seu uso para procedimentos de revascularização do miocárdio no futuro.

Pós operatório: dor relacionada à ressecção costal e/ou muscular abdominal e dormência associada à manipulação de nervos. Possibilidade de cicatrizes hipertóficas, quelóides, hipo ou hiperpigmentação e alargamento cicatricial.

\section{5 - Dos benefícios para o participante:}

Paciente recuperará função oral, como alimentação, continência, higiene, fala e contorno facial após tratamento oncológico que compromete qualidade de vida e convívio social. O participante se beneficiará da reconstrução funcional em cabeça e pescoço com uso de retalho pediculado baseado na artéria torácica interna em situação onde não há outra alternativa para reconstrução ou cobertura.

\section{6 - Dos procedimentos alternativos:}

Como trata-se de um procedimento de resgate em pacientes sem condições de outro tipo de reconstrução, não há consenso na literatura quanto a outras alternativas. O senhor/a pode optar por não reconstruir, em alguns casos, e ficar com ferida aberta aguardando cicatrização. Pode optar por não ressecar novamente o tumor e desistir do tratamento cirúrgico oncológico. Pode optar por outras alternativas experimentais que visam a transferir vasos para a região cervical a fim de permitir o transplante microcirúrgico.

7 - Garantia de acesso: em qualquer etapa do estudo, você terá acesso aos profissionais responsáveis pela pesquisa para esclarecimento de eventuais dúvidas. O principal investigador é o $\mathrm{Dr}$ Guilherme Cardinali Barreiro. que pode ser encontrado no endereço: Av. Dr. Arnaldo, 455, LIM04 Cerqueira César CEP: 01246-903 - São Paulo - SP Telefone(s): 1130617316 e 1130620415. Se você tiver alguma consideração ou dúvida sobre a ética da pesquisa, entre em contato com o Comitê de Ética em Pesquisa (CEP) - Rua Ovídio Pires de Campos, 225 - 5aaa - tel: 3069-6442 ramais 16, 17, 18 ou 20, FAX: 3069-6442 ramal 26 - E-mail: cappesq@hcnet.usp.br

8 - É garantida a liberdade da retirada de consentimento a qualquer momento e deixar de participar do estudo, sem qualquer prejuízo à continuidade de seu tratamento na Instituição;

9 - Direito de confidencialidade: As informações obtidas serão analisadas em conjunto com outros pacientes, não sendo divulgado a identificação de nenhum paciente; 
10 - Direito de ser mantido atualizado sobre os resultados parciais das pesquisas, quando em estudos abertos, ou de resultados que sejam do conhecimento dos pesquisadores;

11 - Despesas e compensações: não há despesas pessoais para o participante em qualquer fase do estudo, incluindo exames e consultas. Também não há compensação financeira relacionada à sua participação. Se existir qualquer despesa adicional, ela será absorvida pelo orçamento da pesquisa.

12 - Compromisso do pesquisador de utilizar os dados e o material coletado somente para esta pesquisa.

Acredito ter sido suficientemente informado a respeito das informações que li ou que foram lidas para mim, descrevendo o estudo "Estudo da anatomia dos retalhos pediculados da artéria torácica interna e sua aplicabilidade na reconstrução de cabeça e pescoço". Eu discuti com o Dr. Guilherme Cardinali Barreiro sobre a minha decisão em participar nesse estudo. Ficaram claros para mim quais são os propósitos do estudo, os procedimentos a serem realizados, seus desconfortos e riscos, as garantias de confidencialidade e de esclarecimentos permanentes. Ficou claro também que minha participação é isenta de despesas e que tenho garantia do acesso a tratamento hospitalar quando necessário. Concordo voluntariamente em participar deste estudo e poderei retirar o meu consentimento a qualquer momento, antes ou durante o mesmo, sem penalidades ou prejuízo ou perda de qualquer benefício que eu possa ter adquirido, ou no meu atendimento neste Serviço.

Assinatura do paciente/representante legal

Data

11

Assinatura da testemunha

Data

para casos de pacientes menores de 18 anos, analfabetos, semi-analfabetos ou portadores de deficiência auditiva ou visual.

Declaro que obtive de forma apropriada e voluntária o Consentimento Livre e Esclarecido deste paciente ou representante legal para a participação neste estudo. 


\section{ANEXO C}

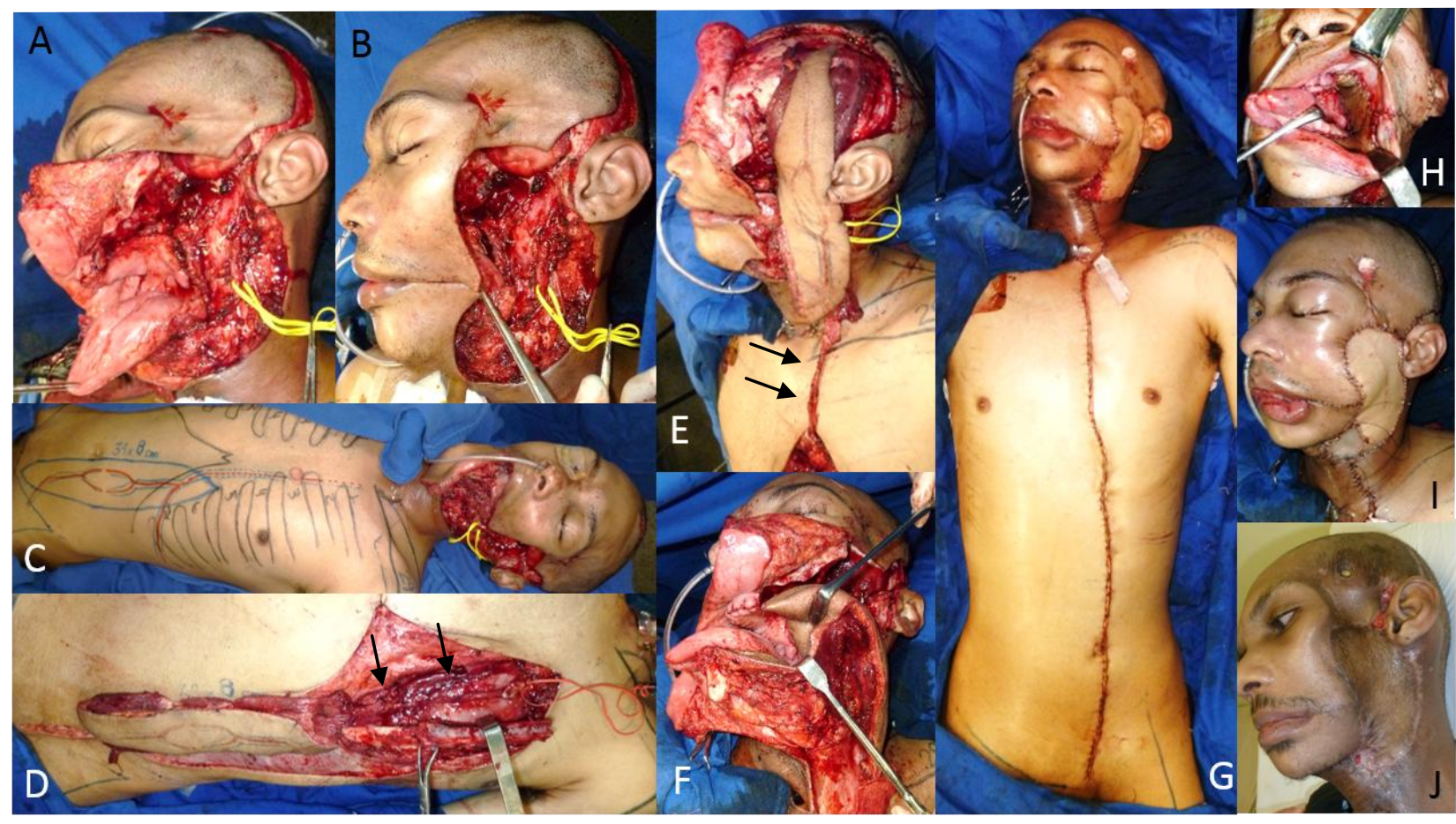

Figura 31: Paciente n. 1, 31 a. A e B: Ressecção de sarcoma pleomórfico de base de crânio recidivado por RTX de campo estendido exclusiva. Defeito cutâneo cervical e bochecha E, mandibulectomia e maxilectomia $\mathrm{E}$, rino e orofaringe + cavidade oral. C: desenho do retalho VRAM estendido pediculado na torácica interna E. D: esternotomia em "L" invertido rabatida expondo torácica interna $\mathrm{E}$, e retalho miocutâneo VRAM já dissecado. As setas apontam para o pedículo vascular. E: retalho miocutâneo rodado para segmento cefálico. É possível ver o pedículo torácico interno deitado sobre a pele do tórax superior do paciente (setas negras). F: síntese da cavidade oral e orofaringe com ilha de pele do VRAM. G: fechamento primário da área doadora no pós operatório imediato. H: detalhe do fechamento intraoral. I: aspecto pós operatório imediato com restante da ilha de pele utilizado para cobertura cutânea e músculo reto abdominal para preenchimento. J: pós operatório de 6 meses com QTX e RTX adjuvantes. Retalho integrado, com recuperação da fonação e da deglutição. 


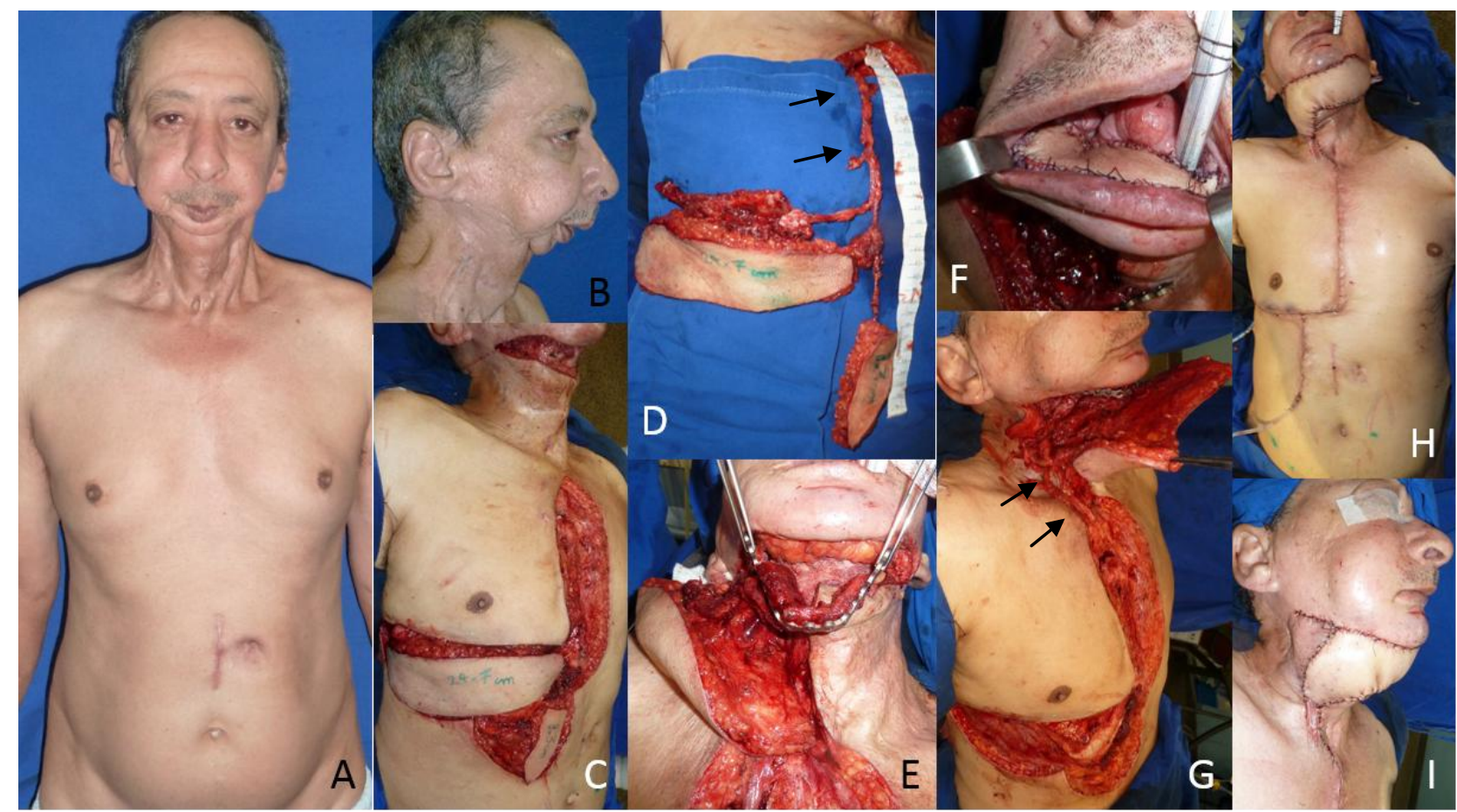

Figura 32: Paciente n. 3, 54 a. A e B: paciente com deformidade de Andy Gump pós ressecção de CEC de gengiva e mandíbula anteriores. C e D: retalho osteomiocutâneo baseado na torácica interna dissecado. Contém $6^{\text {a }}$ costela e pele suprajacente, e componente miocutâneo de reto abdominal. Os vasos torácicos internos estão indicados pelas setas negras. E: moldagem da sexta costela para reconstrução da mandíbula. F: componente miocutâneo do reto abdominal para reconstrução do assoalho oral. G: fechamento do defeito cutâneo com pele irrigada pelas perfurante intercostais. O pedículo encontra-se sobre a pele (setas pretas). $\mathbf{H}$ : detalhe do fechamento intraoral. I: aspecto pós operatório imediato com fechamento primário da área doadora. J: correção da deformidade facial e da retrusão de terço inferior. 


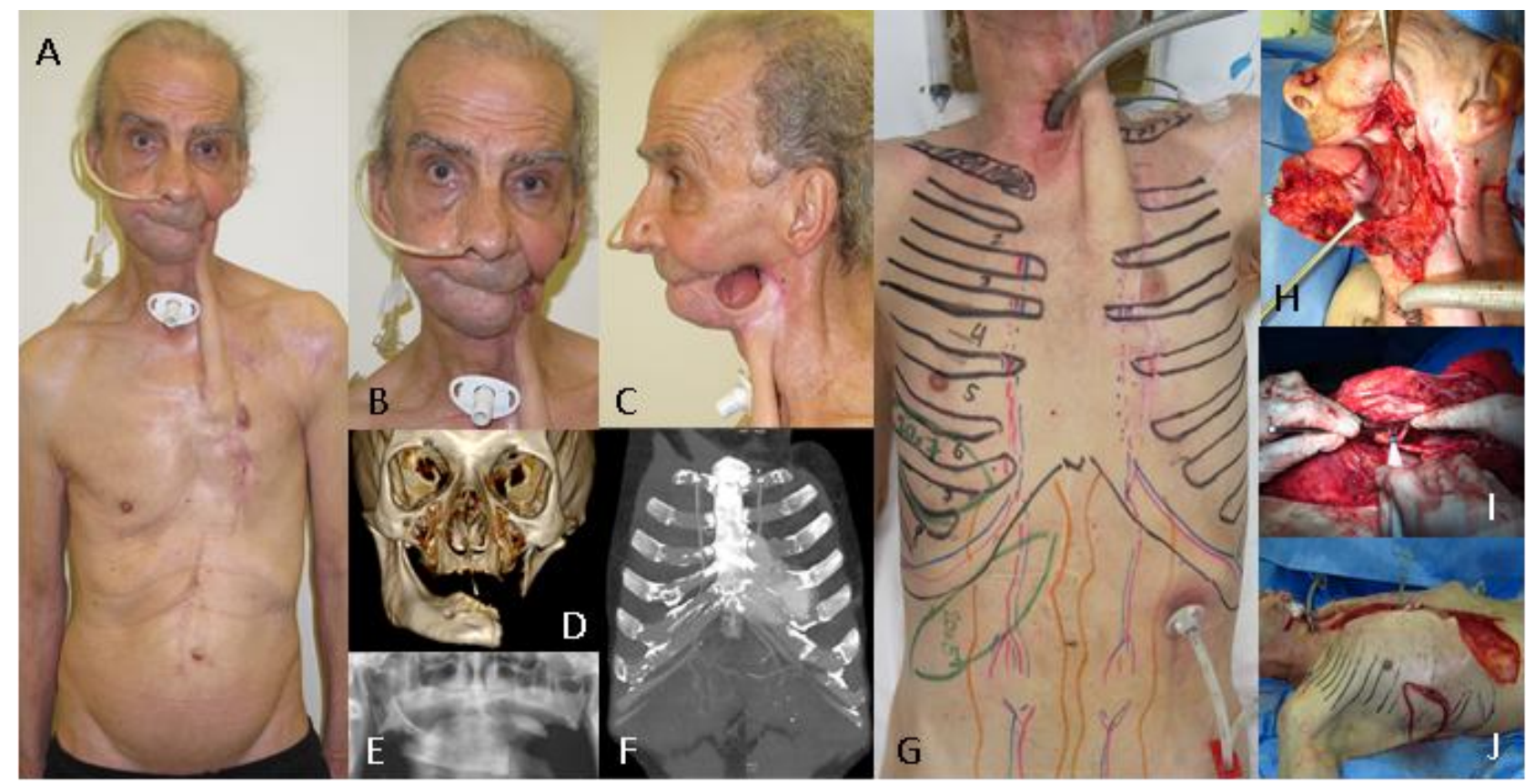

Figura 33: Paciente n. 4, 68 a. A: Condição pós operatória de ressecção de CEC de trígono retromolar $\mathrm{E}+\mathrm{RTX}$ e tentativas de reconstrução com retalhos peitoral, deltopeitoral e de língua E. B e C: detalhe do defeito facial com déficit de mandíbula, incontinência oral completa com orifício lateral esquerdo de $6 \mathrm{~cm}$ de diâmetro, aderência da lígua e estenose faríngea. D e E: defeito ósseo mandibular $\mathrm{E}$ de parassínfise a côndilo. Imagem de reconstrução tridimensional e raio $X$ simples. $\mathbf{F}$ : imagem angiotomográfica evidenciando o pedículo torácico interno e sua bifurcação em ramos musculofrênicos e DSEA. G: planejamento intra-operatório do retalho. As costelas (preto), pedículos vasculares (vermelho e azul), reto abdominal (laranja) e ilhas de pele (verde) estão demarcadas. H: reconstituição do defeito da cavidade oral com liberação da língua e ampliação do defeito orofaríngeo. I: detalhe do isolamento do pedículo torácico interno em sua posição retrocostal por acessado por esternotomia em "L" invertido. J: retalho miocutâneo do reto abdominal levantado e ilha de pele supracostal definida. 


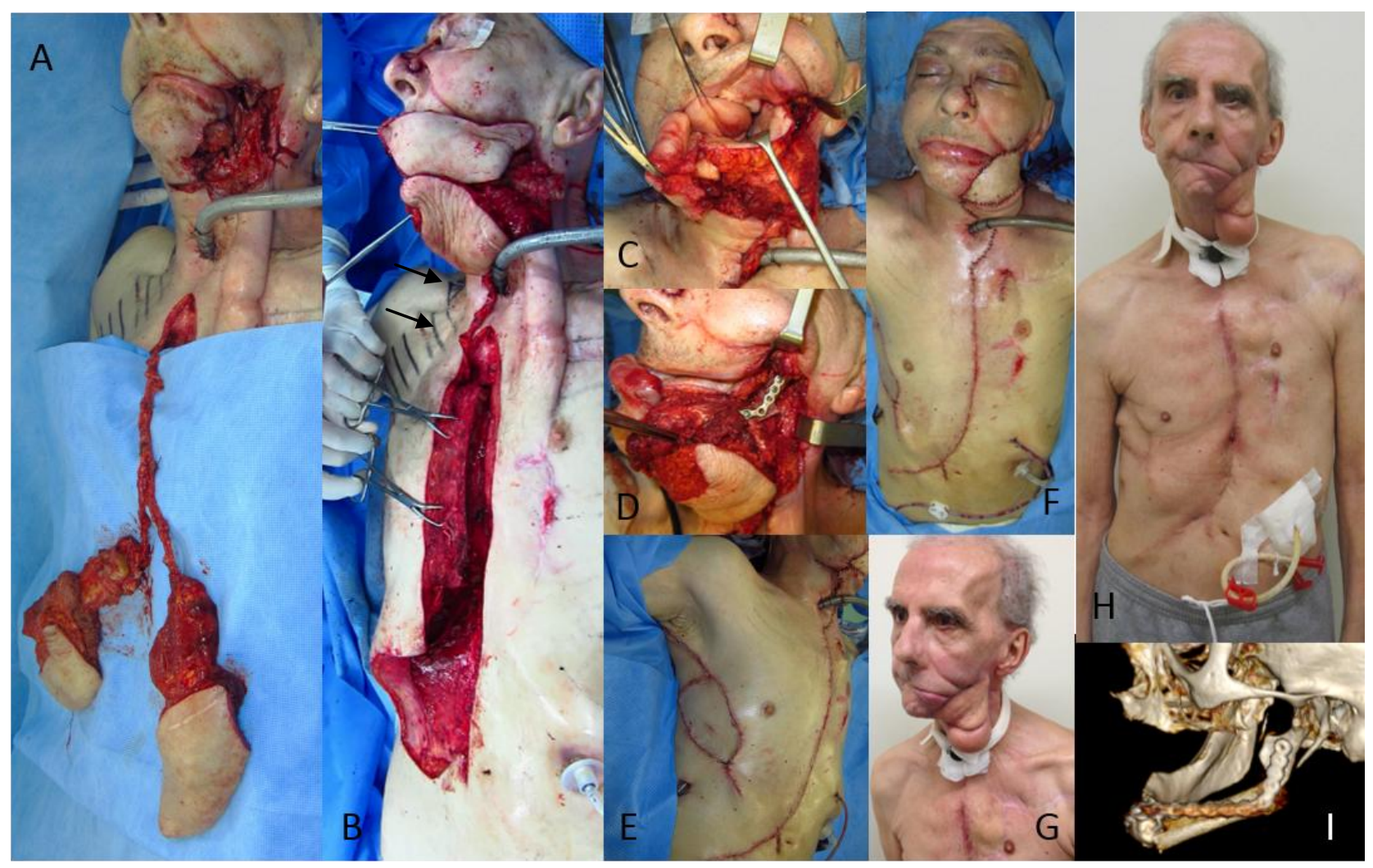

Figura 34: Paciente n. 4, 68 a. A: retalho osteomiocutâneo pediculado na torácica interna Componente ósteomiocutâneo contendo $7^{\underline{a}}$ costela e componente miocutâneo do reto abdominal à direita. B: rotação do retalho através da esternotomia em "L invertido" para segmento cefálico. O pedículo vascular está sobre a pele do paciente para posterior ser acomodado no subcutâneo (setas pretas) C: montagem do retalho com reconstrução do assoalho oral, moldagem da costela para defeito mandibular, posicionamento de músculo para preenchimento. D: montagem da costela para reconstrução mandibular e segunda ilha de pele para cobertura cervical. E: aspecto final da área doadora. F: aspecto final com recuperação da projeção de mento e segunda ilha de pele para reconstrução do defeito de pele. G e H: pós operatório de 6 meses com boa integração do retalho, recuperação da continência e alimentação via oral, e adequada capacidade fonatória, em programação de reabilitação odontológica. Porção do retalho deltopeitoral foi mantida para retoque num segundo tempo. I: reconstrução tridimensional de tomografia mostrando boa integração da costela. 


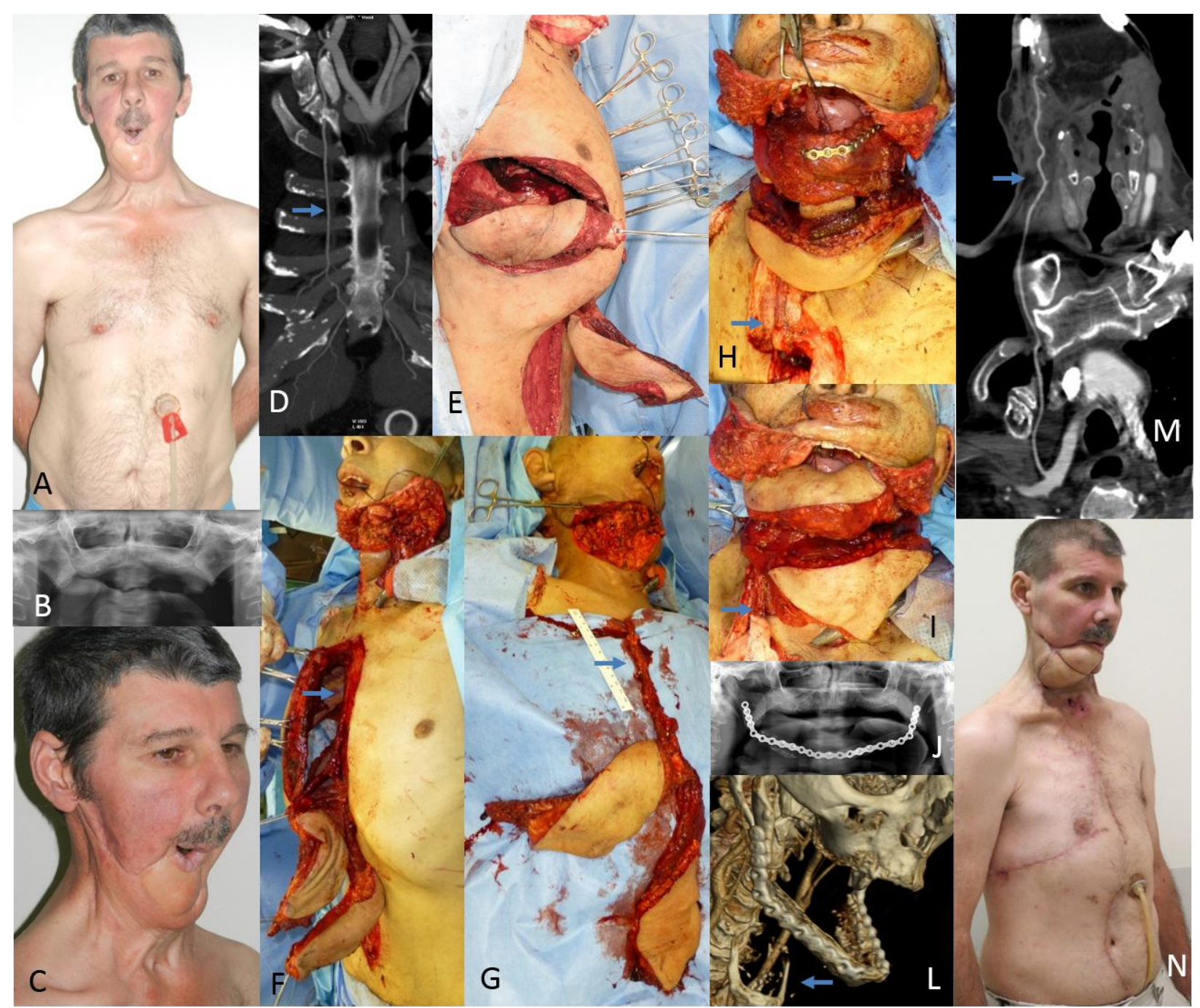

Figura 35: Paciente n. 5, 48 a. A: paciente com deformidade de Andy Gump após pelveglossomandibulectomia com ressecção de pele cervical e do mento. B: Radiografia panorâmica de mandíbula mostra defeito de ramo a ramo. C: paciente apresenta reconstrução de defeito de partes moles com retalho anterolateral da coxa após perda de uma fíbula. D: planejamento pré-operatório com angiotomografia para visualizar trajeto da torácica interna e suas ramificações (setas azuis indicam o pedículo torácico interno). E: retalhos osteomiocutâneo de $7^{\text {a }}$ costela e miocutanêo de reto abdominal levantados. F: Visão intratorácica do pedículo com os dois retalhos e esternotomia em "L invertido". G: retalho osteomiocutâneo pediculado na torácica interna. $\mathbf{H}$ e I: montagem do retalho com reconstrução do assoalho oral, moldagem da costela para defeito mandibular, posicionamento de músculo para preenchimento. Segunda ilha de pele para cobertura cervical. O pedículo encontra-se posicionado no subcutâneo do pescoço (seta azul). J e L: imagens radiológicas da costela integrada nos cotos mandibulares. M: reconstrução angiotomográfica do trajeto do pedículo torácico interno saindo do tronco braquicefálico e atravessando o pescoço até o terço inferior da face. N: pós-operatório 6 meses. Paciente em reabilitação com fonoterapia. 
8. Referências Bibliográficas 
1. Yazar S. Selection of recipient vessels in microsurgical free tissue reconstruction of head and neck defects. Microsurgery 2007;27:588-94.

2. at www.inca.gov.br.

3. Daniel RK, Taylor GI. Distant transfer of an island flap by microvascular anastomoses. A clinical technique. Plast Reconstr Surg 1973;52:111-7.

4. $\quad$ Tamai S. History of microsurgery. Plast Reconstr Surg 2009;124:e282-94.

5. Schusterman MA, Miller MJ, Reece GP, Kroll SS, Marchi M, Goepfert H. A single center's experience with 308 free flaps for repair of head and neck cancer defects. Plast Reconstr Surg 1994;93:472-8; discussion 9-80.

6. Urken ML, Weinberg H, Buchbinder D, et al. Microvascular free flaps in head and neck reconstruction. Report of 200 cases and review of complications. Arch Otolaryngol Head Neck Surg 1994;120:633-40.

7. Hurvitz KA, Kobayashi M, Evans GR. Current options in head and neck reconstruction. Plast Reconstr Surg 2006;118:122e-33e.

8. Hanasono MM, Barnea Y, Skoracki RJ. Microvascular surgery in the previously operated and irradiated neck. Microsurgery 2009;29:1-7.

9. Head C, Sercarz JA, Abemayor E, Calcaterra TC, Rawnsley JD, Blackwell KE. Microvascular reconstruction after previous neck dissection. Arch Otolaryngol Head Neck Surg 2002;128:328-31.

10. Wei FC, Demirkan F, Chen HC, Chen IH, Liao CT, Hau SP. Management of secondary soft-tissue deficits following microsurgical head and neck reconstruction by means of another free flap. Plast Reconstr Surg 1999;103:1158-66.

11. Yazar S, Wei FC, Chen HC, et al. Selection of recipient vessels in double free-flap reconstruction of composite head and neck defects. Plast Reconstr Surg 2005;115:1553-61.

12. Wei FC, Yazar S, Lin $\mathrm{CH}$, Cheng MH, Tsao CK, Chiang YC. Double free flaps in head and neck reconstruction. Clinics in plastic surgery 2005;32:303-8, v.

13. Demirkan F, Wei FC, Chen HC, Chen IH, Hau SP, Liau CT. Microsurgical reconstruction in recurrent oral cancer: use of a second free flap in the same patient. Plast Reconstr Surg 1999;103:829-38.

14. Knoetgen J, 3rd, Choudry U, Finical SJ, Johnson $\mathrm{CH}$. Head and neck reconstruction with a second free flap following resection of a recurrent malignancy. Ann Plast Surg 2005;55:378-83.

15. Okazaki M, Asato $H$, Takushima A, et al. Analysis of salvage treatments following the failure of free flap transfer caused by vascular thrombosis in reconstruction for head and neck cancer. Plast Reconstr Surg 2007;119:1223-32.

16. Takamatsu A, Harashina T, Inoue T. Selection of appropriate recipient vessels in difficult, microsurgical head and neck reconstruction. Journal of reconstructive microsurgery 1996;12:499-507; discussion 8-13.

17. Harris JR, Lueg E, Genden E, Urken ML. The thoracoacromial/cephalic vascular system for microvascular anastomoses in the vessel-depleted neck. Arch Otolaryngol Head Neck Surg 2002;128:319-23.

18. Shimizu F, Lin MP, Ellabban M, Evans GR, Cheng MH. Superficial temporal vessels as a reserve recipient site for microvascular head and neck reconstruction in vessel-depleted neck. Ann Plast Surg 2009;62:134-8.

19. Vogt PM, Steinau HU, Spies M, et al. Outcome of simultaneous and staged microvascular free tissue transfer connected to arteriovenous loops in areas lacking recipient vessels. Plast Reconstr Surg 2007;120:1568-75. 
20. Jacobson AS, Eloy JA, Park E, Roman B, Genden EM. Vessel-depleted neck: techniques for achieving microvascular reconstruction. Head Neck 2008;30:201-7.

21. Longmire WP, Jr. A modification of the Roux technique for antethoracic esophageal reconstruction. Surgery 1947;22:94-100.

22. Harashina $\mathrm{T}$, Imai $\mathrm{T}$, Nakajima $\mathrm{H}$, Fujino $\mathrm{T}$. Breast reconstruction with microsurgical free composite tissue transplantation. Br J Plast Surg 1980;33:30-7.

23. Shaw WW. Breast reconstruction by superior gluteal microvascular free flaps without silicone implants. Plast Reconstr Surg 1983;72:490-501.

24. Urban V, Fritsche E. Internal thoracic vessels as recipient vessels for free flap reconstruction in head and neck surgery. J Plast Reconstr Aesthet Surg 2006;59:1348-9.

25. Yagi S, Kamei Y, Fujimoto Y, Torii S. Use of the internal mammary vessels as recipient vessels for an omental flap in head and neck reconstruction. Ann Plast Surg 2007;58:531-5.

26. Koshima I, Soeda S. Inferior epigastric artery skin flaps without rectus abdominis muscle. Br J Plast Surg 1989;42:645-8.

27. Kalender V, Aydm $H$, Karabulut AB, Ozcan M, Amiraslanov A. Breast reconstruction with the internal mammary artery pedicled fasciocutaneous island flap: description of a new flap. Plast Reconstr Surg 2000;106:1494-8; discussion 9-500.

28. Schoeller T, Bauer T, Haug M, Otto A, Wechselberger G, Piza-Katzer H. A new contralateral split-breast flap for breast reconstruction and its salvage after complication: an alternative for select patients. Ann Plast Surg 2001;47:442-5.

29. Munhoz AM, Ishida LH, Montag E, et al. Perforator flap breast reconstruction using internal mammary perforator branches as a recipient site: an anatomical and clinical analysis. Plast Reconstr Surg 2004;114:62-8.

30. Yu P, Roblin P, Chevray P. Internal mammary artery perforator (IMAP) flap for tracheostoma reconstruction. Head Neck 2006;28:723-9.

31. Neligan PC, Gullane PJ, Vesely M, Murray D. The internal mammary artery perforator flap: new variation on an old theme. Plast Reconstr Surg 2007;119:891-3.

32. Vesely MJ, Murray DJ, Novak CB, Gullane PJ, Neligan PC. The internal mammary artery perforator flap: an anatomical study and a case report. Ann Plast Surg 2007;58:156-61.

33. Schellekens PP, Paes EC, Hage JJ, van der Wal MB, Bleys RL, Kon M. Anatomy of the vascular pedicle of the internal mammary artery perforator (IMAP) flap as applied for head and neck reconstruction. J Plast Reconstr Aesthet Surg 2011;64:53-7.

34. Iyer NG, Clark JR, Ashford BG. Internal mammary artery perforator flap for head and neck reconstruction. ANZ J Surg 2009;79:799-803.

35. Yu BT, Hsieh CH, Feng GM, Jeng SF. Clinical application of the internal mammary artery perforator flap in head and neck reconstruction. Plast Reconstr Surg 2013;131:520e-6e.

36. Hefel L, Schwabegger A, Ninkovic M, et al. Internal mammary vessels: anatomical and clinical considerations. Br J Plast Surg 1995;48:527-32.

37. Taylor GI. The angiosomes of the body and their supply to perforator flaps. Clinics in plastic surgery 2003;30:331-42, v.

38. Palmer JH, Taylor GI. The vascular territories of the anterior chest wall. $\mathrm{Br} \mathrm{J}$ Plast Surg 1986;39:287-99.

39. Miles BA, Goldstein DP, Gilbert RW, Gullane PJ. Mandible reconstruction. Curr Opin Otolaryngol Head Neck Surg 2010;18:317-22. 
40. Blackwell KE, Buchbinder D, Biller HF, Urken ML. Reconstruction of massive defects in the head and neck: the role of simultaneous distant and regional flaps. Head Neck 1997;19:620-8.

41. Banerjee AR, Westmore GA. Free rib graft reconstruction of the mandible: a forgotten option? Ann R Coll Surg Engl 1995;77:278-82.

42. Kim PD, Blackwell KE. Latissimus-serratus-rib free flap for oromandibular and maxillary reconstruction. Arch Otolaryngol Head Neck Surg 2007;133:791-5.

43. Deen HG, Zimmerman RS, Lanza LA. Vascular pedicle rib graft in anterior transthoracic fusion procedures. Technical note. J Neurosurg 1999;90:155-8.

44. Sundaresh DC, Gopalakrishnan D, Shetty N. Vascularised rib graft defects of the diaphysis of the humerus in children. A report of two cases. J Bone Joint Surg $\mathrm{Br}$ 2000;82:28-32.

45. Miller LB, Bostwick J, 3rd, Hartrampf CR, Jr., Hester TR, Jr., Nahai F. The superiorly based rectus abdominis flap: predicting and enhancing its blood supply based on an anatomic and clinical study. Plast Reconstr Surg 1988;81:713-24.

46. Boyd JB, Taylor GI, Corlett R. The vascular territories of the superior epigastric and the deep inferior epigastric systems. Plast Reconstr Surg 1984;73:116.

47. Davison SP, Boehmler JH, Ganz JC, Davidson B. Vascularized rib for facial reconstruction. Plast Reconstr Surg 2004;114:15-20.

48. Strauch B, Bloomberg AE, Lewin ML. An experimental approach to mandibular replacement: island vascular composite rib grafts. $\mathrm{Br} J$ Plast Surg 1971;24:334-41.

49. Ketchum LD, Masters FW, Robinson DW. Mandibular reconstruction using a composite island rib flap. Case report. Plast Reconstr Surg 1974;53:471-6.

50. Ariyan S, Finseth FJ. The anterior chest approach for obtaining free osteocutaneous rib grafts. Plast Reconstr Surg 1978;62:676-85.

51. Cook DW, Winek T, Yeager R, Olivier T, McConnell D, Sasaki T. Mandibular reconstruction in an irradiated field using median sternotomy and anterior rib axial graft. Laryngoscope 1988;98:349-52.

52. Arons JA, Guyuron B. Use of a rectus abdominis osteomyocutaneous double island flap based on internal mammary vessels. Br J Plast Surg 1995;48:145-9.

53. Dee R. Who assisted whom? Tex Heart Inst J 2003;30:90.

54. Haller JD, Olearchyk AS. Cardiology's 10 greatest discoveries. Tex Heart Inst J 2002;29:342-4.

55. Kolessov VI. Mammary artery-coronary artery anastomosis as method of treatment for angina pectoris. J Thorac Cardiovasc Surg 1967;54:535-44.

56. Tosaka Y, Nakazawa S, Takahashi Y, Kanazawa H, Yamazaki Y. Inverted Lshape sternotomy as a minimally invasive approach: re-do cardiac surgery for papillary muscle rupture. The Japanese journal of thoracic and cardiovascular surgery : official publication of the Japanese Association for Thoracic Surgery = Nihon Kyobu Geka Gakkai zasshi 2004;52:570-3.

57. Ravitch MM. The Operative Treatment of Pectus Excavatum. Ann Surg 1949;129:429-44.

58. Haller JA, Jr., Shermeta DW, Tepas JJ, Bittner HR, Golladay ES. Correction of pectus excavatum without prostheses or splints: objective measurement of severity and management of asymmetrical deformities. Ann Thorac Surg 1978;26:739. 
59. Coelho MdS, Stori Júnior WdS, Pizarro LDV, Zanin SA, Gonçalves JL, Bergonse Neto N. Pectus Excavatum / Pectus Carinatum: tratamento cirúrgico. Revista do Colégio Brasileiro de Cirurgiões 2003;30:249-61.

60. Schmidt M, Aszmann OC, Beck H, Frey $M$. The anatomic basis of the internal mammary artery perforator flap: a cadaver study. J Plast Reconstr Aesthet Surg 2010;63:191-6.

61. Rosner B. Fundamentals of biostatistics : study guide. 4th ed. Belmont, Calif: Duxbury Press; 1995.

62. Bakamjian VY. A Two-Stage Method for Pharyngoesophageal Reconstruction with a Primary Pectoral Skin Flap. Plast Reconstr Surg 1965;36:17384.

63. Ariyan S. Further experiences with the pectoralis major myocutaneous flap for the immediate repair of defects from excisions of head and neck cancers. Plast Reconstr Surg 1979;64:605-12.

64. Ariyan S. The pectoralis major myocutaneous flap. A versatile flap for reconstruction in the head and neck. Plast Reconstr Surg 1979;63:73-81.

65. Harii K, Ohmori K, Torii S. Free gracilis muscle transplantation, with microneurovascular anastomoses for the treatment of facial paralysis. A preliminary report. Plast Reconstr Surg 1976;57:133-43.

66. Taylor GI, Miller GD, Ham FJ. The free vascularized bone graft. A clinical extension of microvascular techniques. Plast Reconstr Surg 1975;55:533-44.

67. Cuono CB, Ariyan S. Immediate reconstruction of a composite mandibular defect with a regional osteomusculocutaneous flap. Plast Reconstr Surg 1980;65:477-84.

68. Richards MA, Poole MD, Godfrey AM. The serratus anterior/rib composite flap in mandibular reconstruction. Br J Plast Surg 1985;38:466-77.

69. Siemssen SO, Kirkby B, O'Connor TP. Immediate reconstruction of a resected segment of the lower jaw, using a compound flap of clavicle and sternomastoid muscle. Plast Reconstr Surg 1978;61:724-35.

70. Panje W, Cutting C. Trapezius osteomyocutaneous island flap for reconstruction of the anterior floor of the mouth and the mandible. Head Neck Surg 1980;3:66-71.

71. Hendel PM, Hattner RS, Rodrigo J, Buncke HJ. The functional vascular anatomy of rib. Plast Reconstr Surg 1982;70:578-87.

72. Song R, Lu C, Song Y, Liu J. Repair of large mandibular defects with vascularized rib grafts. Clinics in plastic surgery 1982;9:73-8.

73. Serafin D, Villarreal-Rios A, Georgiade NG. A rib-containing free flap to reconstruct mandibular defects. Br J Plast Surg 1977;30:263-6.

74. O'Brien BM, Morrison WA, MacLeod AM, Dooley BJ. Microvascular osteocutaneous transfer using the groin flap and iliac crest and the dorsalis pedis flap and second metatarsal. Br J Plast Surg 1979;32:188-206.

75. Taylor GI, Townsend P, Corlett R. Superiority of the deep circumflex iliac vessels as the supply for free groin flaps. Plast Reconstr Surg 1979;64:595-604.

76. Soutar DS, Scheker LR, Tanner NS, McGregor IA. The radial forearm flap: a versatile method for intra-oral reconstruction. Br J Plast Surg 1983;36:1-8.

77. MacLeod AM, Robinson DW. Reconstruction of defects involving the mandible and floor of mouth by free osteo-cutaneous flaps derived from the foot. $\mathrm{Br} \mathrm{J}$ Plast Surg 1982;35:239-46.

78. Hidalgo DA. Fibula free flap: a new method of mandible reconstruction. Plast Reconstr Surg 1989;84:71-9. 
79. Flemming AF, Brough MD, Evans ND, et al. Mandibular reconstruction using vascularised fibula. Br J Plast Surg 1990;43:403-9.

80. Wei FC, Chen HC, Chuang CC, Noordhoff MS. Fibular osteoseptocutaneous flap: anatomic study and clinical application. Plast Reconstr Surg 1986;78:191-200.

81. Hamdi M, Blondeel $\mathrm{P}$, Van Landuyt K, Monstrey S. Algorithm in choosing recipient vessels for perforator free flap in breast reconstruction: the role of the internal mammary perforators. Br J Plast Surg 2004;57:258-65.

82. Saint-Cyr M, Wong C, Schaverien M, Mojallal A, Rohrich RJ. The perforasome theory: vascular anatomy and clinical implications. Plast Reconstr Surg 2009;124:1529-44.

83. Harii K, Omori K, Omori S. Free deltopectoral skin flaps. Br J Plast Surg 1974;27:231-9.

84. Sasaki K, Nozaki M, Honda T, Morioka K, Kikuchi Y, Huang T. Deltopectoral skin flap as a free skin flap revisited: further refinement in flap design, fabrication, and clinical usage. Plast Reconstr Surg 2001;107:1134-41.

85. Taylor GI, Palmer JH. The vascular territories (angiosomes) of the body: experimental study and clinical applications. British journal of plastic surgery 1987;40:113-41.

86. Uemura T. Superior epigastric artery perforator flap: preliminary report. Plast Reconstr Surg 2007;120:1e-5e.

87. Moore KL, Dalley AF, Agur AMR. Clinically oriented anatomy. 6th ed. Philadelphia: Wolters Kluwer Health/Lippincott Williams \& Wilkins; 2010.

88. Schwabegger AH, Piza-Katzer H, Pauzenberger R, Del Frari B. The internal mammary artery perforator (IMAP) breast-flap harvested from an asymmetric hyperplastic breast for correction of a mild funnel chest deformity. Aesthetic plastic surgery $2011 ; 35: 928-32$.

89. Schwabegger $\mathrm{AH}$, Moriggl $\mathrm{B}$, Waldenberger $\mathrm{P}$, et al. [Use of the internal mammary artery in reconstructive microsurgery in the thoracic region: anatomicalradiologic study]. Handchirurgie, Mikrochirurgie, plastische Chirurgie : Organ der Deutschsprachigen Arbeitsgemeinschaft fur Handchirurgie : Organ der Deutschsprachigen Arbeitsgemeinschaft fur Mikrochirurgie der Peripheren Nerven und Gefasse 1998;30:87-94.

90. Wilkins EG, August DA, Kuzon WM, Jr., Chang AE, Smith DJ. Immediate transverse rectus abdominis musculocutaneous flap reconstruction after mastectomy. Journal of the American College of Surgeons 1995;180:177-83.

91. Hartrampf CR, Scheflan M, Black PW. Breast reconstruction with a transverse abdominal island flap. Plast Reconstr Surg 1982;69:216-25.

92. Hartrampf CR, Jr. The transverse abdominal island flap for breast reconstruction. A 7-year experience. Clinics in plastic surgery 1988;15:703-16.

93. Sajjadian A, Rubinstein R, Naghshineh N. Current status of grafts and implants in rhinoplasty: part I. Autologous grafts. Plast Reconstr Surg 2010;125:40e9 e.

94. Tessier $\mathrm{P}$, Kawamoto $\mathrm{H}$, Matthews $\mathrm{D}$, et al. Autogenous bone grafts and bone substitutes--tools and techniques: I. A 20,000-case experience in maxillofacial and craniofacial surgery. Plast Reconstr Surg 2005;116:6S-24S; discussion 92S-4S.

95. Tessier $P$, Kawamoto $H$, Matthews $D$, et al. Taking long rib grafts for facial reconstruction--tools and techniques: III. A 2900-case experience in maxillofacial and craniofacial surgery. Plast Reconstr Surg 2005;116:38S-46S; discussion 92S-4S.

96. Yavuz SS, Tarcin O, Ada S, et al. Incidence, aetiology, and control of sternal surgical site infections. The Journal of hospital infection 2013. 
97. Lepelletier D, Bourigault C, Roussel JC, et al. Epidemiology and prevention of surgical site infections after cardiac surgery. Medecine et maladies infectieuses 2013.

98. Centofanti P, Savia F, La Torre M, et al. A prospective study of prevalence of 60 -days postoperative wound infections after cardiac surgery. An updated risk factor analysis. The Journal of cardiovascular surgery 2007;48:641-6.

99. Brown ML, McKellar SH, Sundt TM, Schaff HV. Ministernotomy versus conventional sternotomy for aortic valve replacement: a systematic review and metaanalysis. J Thorac Cardiovasc Surg 2009;137:670-9 e5.

100. Farhat F, Metton O, Jegaden O. Benefits and complications of total sternotomy and ministernotomy in cardiac surgery. Surgical technology international 2004;13:199-205. 